Luis López-U rrutia Lorente

\title{
Inducción de la producción de óxido nítrico por lipopolisacárido de Brucella en macrófagos de rata
}




\section{COLECCIÓN VITOR}

49

c

Ediciones Universidad de Salamanca

y Luis López-Urrutia Lorente

$1^{\text {a }}$ edición:

I.S.B.N. : 84-7800-934-5

Depósito Legal: S. 440-2000

Ediciones Universidad de Salamanca

Apartado postal 325

E-37080 Salamanca (España)

Realizacion:

Nematica, S.L.

Impreso en España - Printed in Spain

Todos los derechos reservados.

Ni la totalidad ni parte de este libro

puede reproducirse ni transmitirse

sin permiso escrito de

Ediciones Universidad de Salamanca

$\kappa$

CEP. Servicio de Bibliotecas

Inducción de la producción de óxido nítrico por lipopolisacárido de "Brucella" en macrófagos de rata [Archivo de ordenador] / Luis LópezUrrutia Lorente.-- $1^{\text {a }}$ ed.--Salamanca : Ediciones Universidad de Salamanca, 2000

1 disco compacto.-- (Colección Vítor ; 49)

Tesis-Universidad de Salamanca, 1999

1. Macrófagos. 2.Brucella. 3. Ratas (Animales de laboratorio). 4.

Universidad de Salamanca (España)- Tesis y disertaciones académicas.

$578.81(460.187)(043.2)$ 


\section{RESUMEN}

Las brucelas son bacterias intracelulares facultativas, capaces de sobrevivir y multiplicarse en el interior de diversas células, incluyendo los macrófagos. Su virulencia y tendencia a producir infecciones crónicas se cree que es debida a su capacidad para resistir los mecanismos bactericidas intracelulares, entre los que se encuentra la producción de óxido nítrico (NO). Teniendo en cuenta que el lipopolisacárido liso (SLPS) de las brucelas ha sido propuesto como factor de virulencia de la mismas y que la mayoría de efectos biológicos del LPS se asocian al lípido A (LípA), nos planteamos como objetivo de esta tesis comprobar si los S-LPS y LípA de Brucella inducían la producción de NO en los macrófagos peritoneales de rata, comparando su efecto con el del LPS y LípA de Escherichia coli. Mostramos como los S-LPS de Brucella abortus 544 y Brucella melitensis $16 \mathrm{M}$ son capaces de inducir la producción de NO por los macrófagos peritoneales de rata de forma dependiente del tiempo y de la dosis. La producción de NO ocurre a través de la vía de la L-arginina, a juzgar por su dependencia de la presencia de L-arginina y el bloqueo por $\mathrm{N}^{\mathrm{G}}$-metil-L-arginina, un inhibidor de las sintasas de NO. La participación de la isoforma inducible de la NO sintasa (iNOS) en la producción de NO iniciada por ambos S-LPS, se demuestra por la inducción de la expresión de ARN mensajero y de la proteína iNOS. Los LípA de Brucella también inducen la producción de NO, de forma dependiente de la dosis, y la expresión de ARNm de iNOS, comportándose como la parte activa del S-LPS en dicha inducción. No encontramos diferencias significativas en cuanto a las cantidades de NO que pueden llegar a producirse por los S-LPS de ambas especies de Brucella, ni tampoco en lo que se refiere a las cantidades producidas por sus LípA, sin embargo a bajas concentraciones, $0.01-0.1 \mu \mathrm{g} / \mathrm{ml}$, se comportan como inductores menos potentes que el LPS y LípA de Escherichia coli. Además mostramos como los lipopolisacáridos 
de Escherichia hermannii, Yersinia enterocolitica O:9, Pseudomonas maltophilia 555 y Ochrobactrum anthropi LMG3331, que presentan reacciones serológicas cruzadas con los S-LPS de Brucella, son capaces de inducir la producción de NO y la expresión de ARNm de iNOS en macrófagos peritoneales de rata. Nuestras observaciones podrían ayudar a explicar el curso agudo de la infección por brucelas en los ratones, la baja frecuencia con que se presenta el cuadro de shock séptico en la brucelosis humana y la prolongada supervivencia intracelular de Brucella en los humanos. 


\section{ABSTRACT}

We show in this study that smooth lipopolysaccharide (S-LPS) of Brucella abortus 544 and Brucella melitensis $16 \mathrm{M}$ are able to induce nitric oxide (NO) production in rat peritoneal macrophages in a time- and dose-dependent manner. The involvement of the L-arginine pathway is supported by the dependence of this production on the presence of L-arginine and the inhibition by $\mathrm{N}^{\mathrm{G}}$-metil-L-arginina, an inhibitor of $\mathrm{NO}$ synthases. Evidence in favour of the involvement of the inducible isoform of the NO synthase (iNOS) are the increased expression of both iNOS mRNA and iNOS protein elicited by both S-LPS. The lipid A (lípA) moieties of SLPS also induced the expression of iNOS mRNA and NO production, thus suggesting that these moieties could be the portion of the S-LPS molecule involved in NO induction. The amounts of NO produced by either S-LPS reached similar values, as well as those elicited by lípA, however, they were less active than their counterparts from Escherichia coli at the range of concentrations 0.01$0.1 \mu \mathrm{g} / \mathrm{ml}$. LPS from Escherichia hermannii, Yersinia enterocolítica O:9, Pseudomonas maltophilia 555 y Ochrobactrum anthropi LMG3331, which show serological crossreactivity with Brucella S-LPS, also induced both iNOS mRNA expression and NO production in rat peritoneal macrophages. These observations might help to explain: i) the acute outcome of Brucella infection in rodents, ii) the low frequency of septic shock in human brucellosis, and iii) the prolonged intracellular survival of Brucella in humans. 
ÍNDICE 


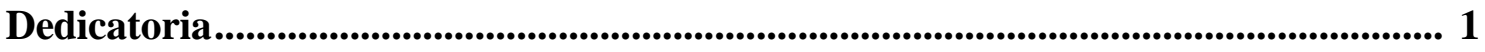

Agradecimientos ............................................................................................................ 2

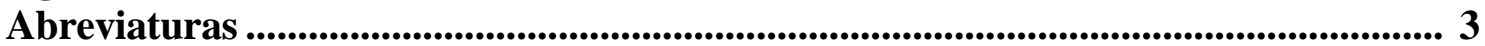



A. MECANISMOS DE DEFENSA ANTIMICROBIANA ……..................................16

A.1. MECANISMOS FAGOCÍTICOS DE DEFENSA ANTIMICROBIANA....16

A.1.1. MARGINACIÓN, QUIMIOTAXIS Y MIGRACIÓN …………………………......16

A.1.2. INGESTIÓN O FAGOCITOSIS....................................................................17

A.1.3. DESGRANULACIÓN, ACTIVACIÓN DE LOS MECANISMOS BACTERICIDAS, MUERTE Y DIGESTIÓN..........................................................................

A.2. MECANISMOS BACTERICIDAS …….................................................................. 18

A.2.1. MECANISMOS OXÍGENO DEPENDIENTES................................................18

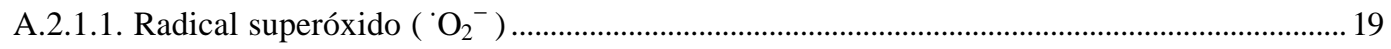

A.2.1.2. Peróxido de hidrógeno $\left(\mathrm{H}_{2} \mathrm{O}_{2}\right)$................................................................................ 19

A.2.1.3. Radical hidroxilo $\left({ }^{\circ} \mathrm{OH}\right)$..................................................................................................... 19

A.2.1.4. Singlete de oxígeno $\left({ }^{1} \mathrm{O}_{2}\right)$........................................................................................20



A.2.2. MECANISMOS OXÍGENO INDEPENDIENTES.............................................22

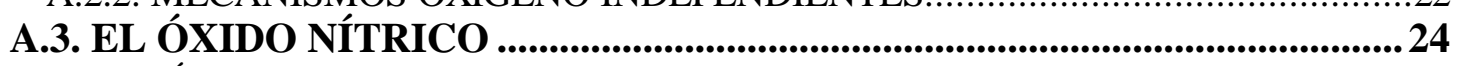

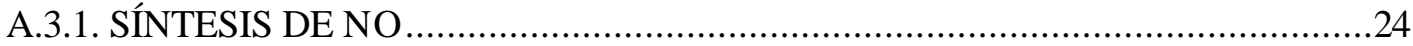

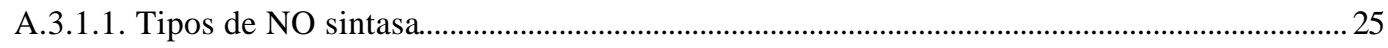

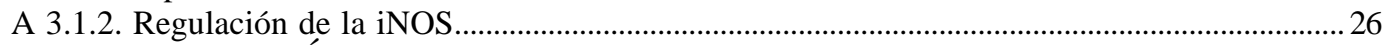

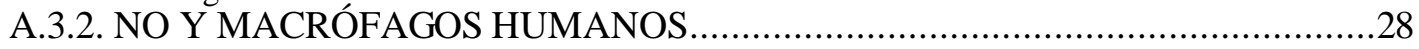

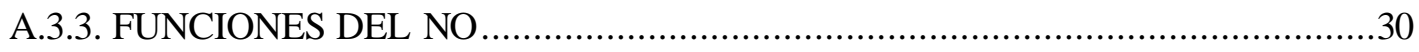



A.3.3.2. Funciones en el sistema inmune y en la inflamación................................................................ 31

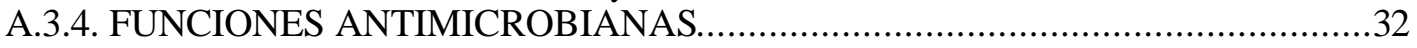

A.3.4.1. Evidencias de la actividad antimicrobiana del NO ............................................................... 32

A.3.4.2. Mecanismos de acción antimicrobiana de los RNI ............................................................. 34

A.3.4.3. Defensas microbianas frente al NO ....................................................................................... 36

B. BRUCELLA ................................................................................................................37

B.1. MECANISMOS DE Brucella PARA EVADIR LAS DEFENSAS .................38

B.1.1. FAGOCITOSIS .........................................................................................

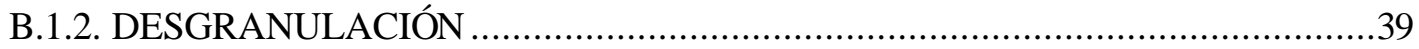

B.1.3. MECANISMOS BACTERICIDAS O ${ }_{2}$-DEPENDIENTES...................................4

B.1.4. MECANISMOS $\mathrm{O}_{2}$-INDEPENDIENTES....................................................41

B.2. DETERMINANTES DE PATOGENICIDAD (mecanismos de virulencia).41

B.2.1. FACTORES METABÓLICOS .......................................................................41

B.2.1.1. Enzimas y otros productos génicos ......................................................................................... 41

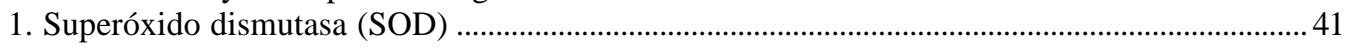

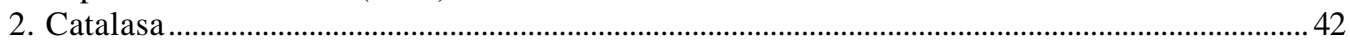

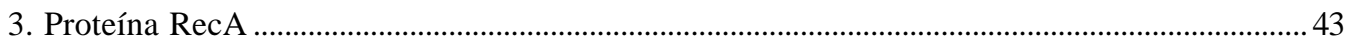

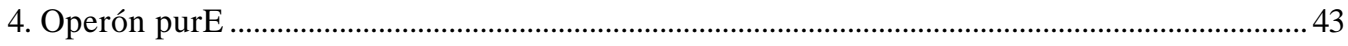

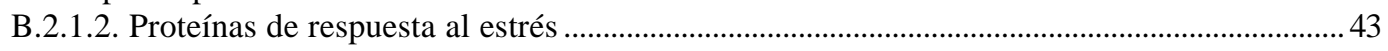

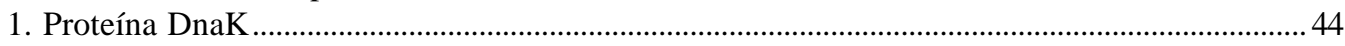

2. Proteína HtrA (High-temperature-requirement A protein)......................................................... 44

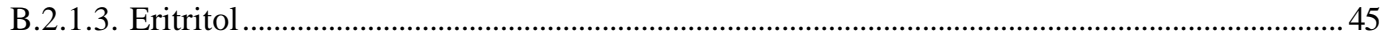

B.2.1.4. Otros determinantes de patogenicidad ................................................................................ 45

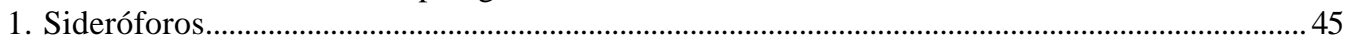

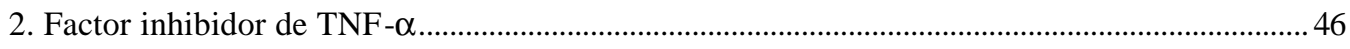

B.2.2. FACTORES DE VIRULENCIA ESTRUCTURALES........................................46 
B.2.2. FACTORES DE VIRULENCIA ESTRUCTURALES...................................46

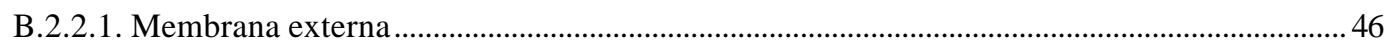

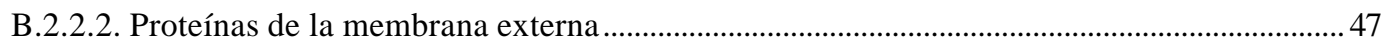

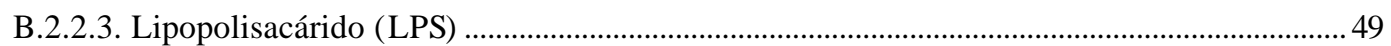

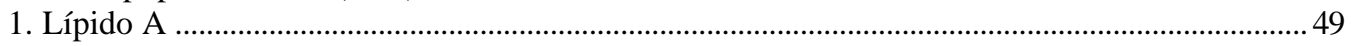

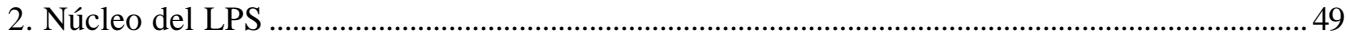

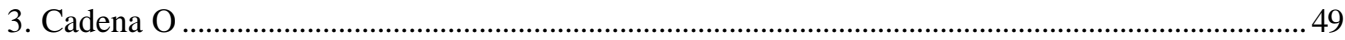

4. Otros lipopolisacáridos relacionados estructuralmente con el LPS de Brucella ........................ 50

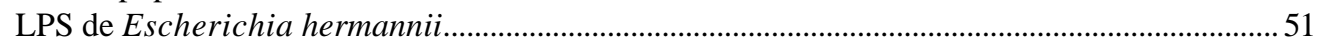

LPS de Yersinia enterocolitica $\mathrm{O}: 9$................................................................................................ 51

LPS de Pseudomonas maltophilia 555 [Stenotrophomonas(Xanthomonas)maltophilia]........ 51

S-LPS de Ochrobactrum anthropi LMG 3331.......................................................................... 52

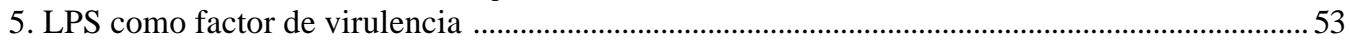

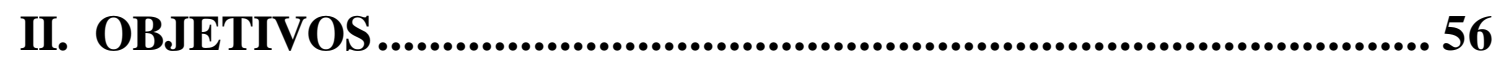

III. MATERIAL Y MÉTODOS................................................58

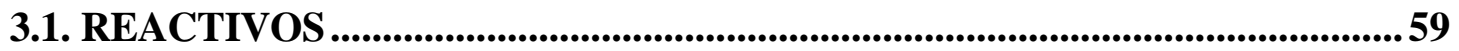

3.2. MEDIOS, TAMPONES Y SOLUCIONES .............................................................64

3.3. MÉTODOS EXPERIMENTALES ………...................................................68

3.3.1. OBTENCIÓN DE LOS LIPOPOLISACÁRIDOS ……………………………......68

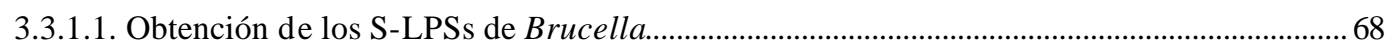

3.3.1.2. Obtención de los lípidos A y polisacáridos $\mathrm{O}$........................................................................ 70

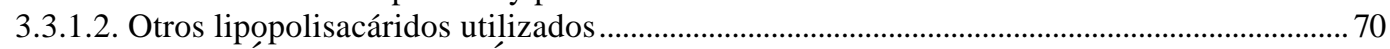

3.3.2. OBTENCIÓN DE MACRÓFAGOS PERITONEALES DE RATA......................71

3.3.3. MEDIDA DE LA PRODUCCIÓN DE NO................................................71

3.3.4. EXTRACCIÓN DE ARN TOTAL...................................................................72

3.3.5. OBTENCIÓN Y MARCAJE DE LAS SONDAS.................................................72

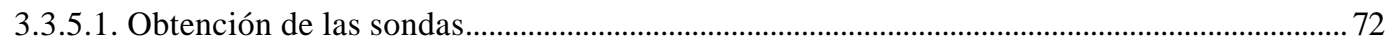

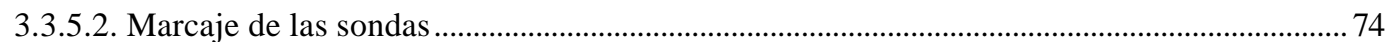

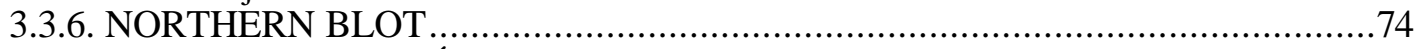

3.3.7. INMUNODETECCIÓN (WESTERN BLOT)....................................................75

3.3.8. ANÁLISIS DE LOS DATOS.......................................................................

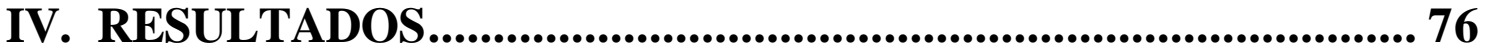

4.1. INDUCCIÓN DE LA PRODUCCIÓN DE NO POR LOS LPSs DE

Escherichia coli, Brucella abortus Y Brucella melitensis .............................. 77

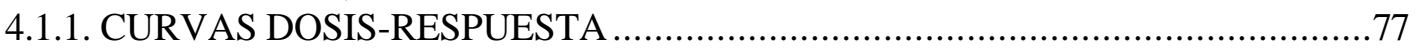

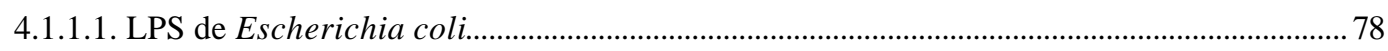

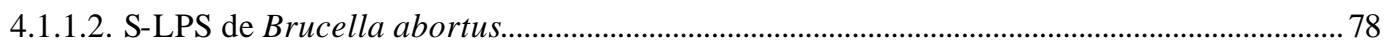

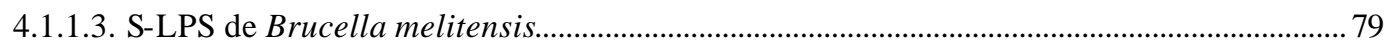

4.1.1.4. Comparación del nivel de NO inducido por los LPSs de E. coli, B. abortus y

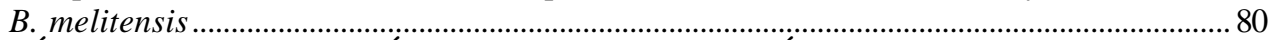

4.1.2. CINÉTICA DE INDUCCIÓN DE LA PRODUCCIÓN DEL NO POR LOS LPSS

DE E. coli, B. abortus Y B. melitensis ..........................................................81

4.2. INDUCCIÓN DE LA PRODUCCIÓN DE NO POR LOS LÍPIDOS A DE

Escherichia coli, Brucella abortus Y Brucella melitensis .............................84

4.2.1. LÍPIDO A DE E. coli ............................................................................... 84



4.2.3. LÍPIDO A DE B. melitensis ........................................................................86

4.2.4. COMPARACIÓN DEL NIVEL DE NO INDUCIDO POR LOS LÍPIDOS A DE

E. coli, B. abortus Y B. melitensis ........................................................... 86

4.2.5. COMPARACIÓN DEL NIVEL DE NO INDUCIDO POR EL S-LPS, LÍPIDO A




4.3. INHIBICIÓN DE LA PRODUCCIÓN DE NO CON L-NMA...........................89

4.3.1. INHIBICIÓN DE LA PRODUCCIÓN DE NO INDUCIDA POR LOS LPSs ...........89

4.3.2. INHIBICIÓN DE LA PRODUCCIÓN DE NO INDUCIDA POR LOS LÍPIDOS A ..90

4.4. INDUCCIÓN DE LA EXPRESIÓN DEL ARNm DE iNOS 91

4.4.1. INDUCCIÓN DEL ARNm DE LA iNOS POR LOS LIPOPOLISACÁRIDOS

DE E. coli, B. abortus Y B. melitensis .........................................................92

4.4.2. PATRÓN TEMPORAL DE LA INDUCCIÓN DEL ARNm DE LA iNOS..............92

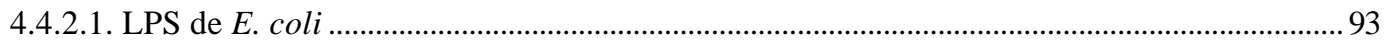

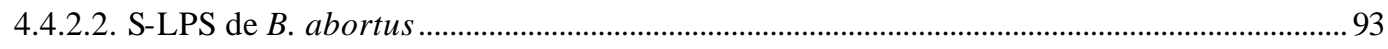

4.4.2.3. S-LPS de B. melitensis................................................................................................94

4.4.3. INDUCCIÓN DEL ARNm DE LA INOS POR LOS LÍPIDOS A DE E. coli,

B. abortus y B. melitensis .....................................................................95

4.5. INDUCCIÓN DE LA EXPRESIÓN DE LA PROTEÍNA DE iNOS ..............96

4.6. OTROS LIPOPOLISACÁRIDOS RELACIONADOS ........................................97

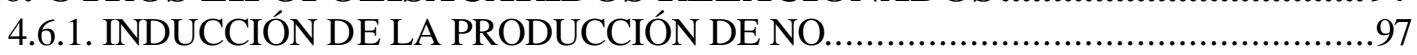

4.6.1.1. LPS de Escherichia hermannii ..................................................................................................97

4.6.1.2. LPS de Yersinia enterocolitica O:9 ….......................................................................................98

4.6.1.3. LPS de Pseudomonas (Xanthomonas) maltophilia............................................................99

4.6.1.4. LPS de Ochrobactrum anthropi .....................................................................................99

4.6.2. INDUCCIÓN DEL ARNm DE LA iNOS POR LOS LIPOPOLISACÁRIDOS DE

E. hermannii, $Y$. enterocolitica, $P$. maltophilia y $O$. anthropi.........................100

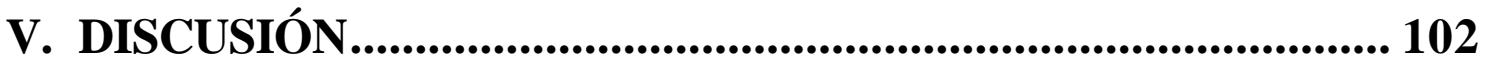

5.1. INDUCCIÓN DE LA PRODUCCIÓN DE NO POR LOS S-LPSs y lípAs DE B. abortus Y B. melitensis........................................................................ 103

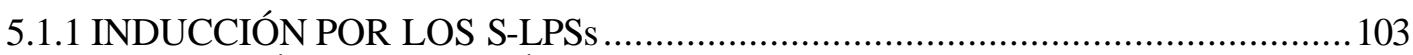

5.1.2. INDUCCIÓN POR LOS LÍPIDOS A............................................................. 104

5.2. LOS S-LPSs DE B. abortus Y B. melitensis INDUCEN LA PRODUCCIÓN

DE NO A TRAVÉS DE LA VÍA DE LA iNOS...................................................106

5.2.1. PERFIL TEMPORAL DE LA INDUCCIÓN........................................................106

5.2.2. DEMOSTRACIÓN DE LA PARTICIPACIÓN DE LA VÍA DE LA L-ARGININA 106

5.2.3. INDUCCIÓN DE LA EXPRESIÓN DEL ARNm DE iNOS....................................106

5.2.4. INDUCCIÓN DE LA EXPRESIÓN DE LA PROTEÍNA DE iNOS.......................107

5.3. INDUCCIÓN DE NO POR LIPOPOLISACÁRIDOS RELACIONADOS

CON EL S-LPS DE Brucella ................................................................109

5.4. ÓXIDO NÍTRICO y Brucella................................................................................. 110

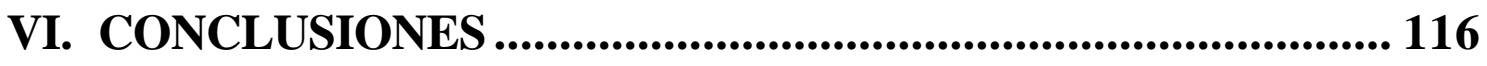

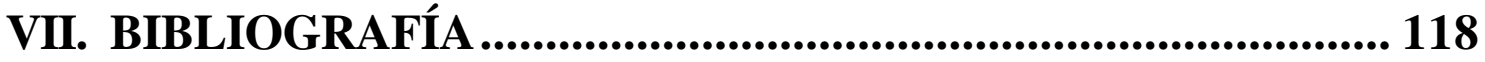


A Inma

A mis padres 


\section{Agradecimientos}

Deseo expresar mi agradecimiento:

Al Dr. Antonio Orduña Domingo, director de este trabajo, por haberme dado la oportunidad de llevar a cabo esta Tesis Doctoral, y al Dr. Mariano Sánchez Crespo, por codirigir este trabajo y permitirme realizarlo en su laboratorio.

Al Dr Antonio Rodríguez Torres por facilitarme los trámites necesarios para la presentación de esta Tesis Doctoral en la Facultad de Farmacia de la Universidad de Salamanca.

Al Dr. Andrés Chordi Corbo, por permitirme presentar esta Tesis Doctoral en el Departamento de Microbiología y Genética de la Facultad de Farmacia de la Universidad de Salamanca, y actuar como tutor en dicho Departamento.

Al Dr. I. Moriyón que nos ha enviado desinteresadamente distintos lipopolisacáridos utilizados en esta Tesis Doctoral.

A mis compañeros de laboratorio durante estos años: Marisa y Marita por su colaboración y apoyo, y en especial quiero expresar mi agradecimiento a Yolanda y Andrés, que con su buen hacer científico y su paciencia, me enseñaron todo lo necesario para llevar a cabo este trabajo: sin su desinteresada e inestimable ayuda y gracias a su generosidad en tiempo, trabajo e ideas he podido realizar este trabajo.

A todas las personas del Departamento de Microbiología y del Departamento de Bioquímica, Biología Molecular y Fisiología de la Facultad de Medicina de Valladolid, del Departamento de Microbiología y Genética de la Facultad de Farmacia de Salamanca y del Servicio de Análisis Clínicos del Hospital Pío del Río Hortega de Valladolid que directa o indirectamente han colaborado en la realización de este trabajo.

A mi familia y amigos por su apoyo y paciencia.

De manera muy especial quiero expresar mi agradecimiento a Inma que ha sufrido durante estos años esta Tesis: gracias a su paciencia, apoyo, comprensión, cariño, estímulo y ayuda pude superar los momentos difíciles y completar este trabajo y periodo de nuestra vida. 
Abreviaturas 
ADN: ácido desoxirribonucleico

$\mathrm{ARN}$ : ácido ribonucleico

ARNm: ácido ribonucleico mensajero

$\mathrm{BH}_{4}$ : tetrahidrobiopterina

biov.: biovariedad

BrEt: bromuro de etidio

BSA: albúmina de suero bovino

DEPC: dietilpirocarbamato

DMEM: Dulbecco’s Modified Eagles Medium

DMSO: dimetilsulfóxido

DTT: Ditiotreitol

EDTA: ácido etilendiamino tetraacético

EGTA: ácido etilenglicol-bis-( $\beta$-aminoetiléter)- $\mathrm{N}, \mathrm{N}, \mathrm{N}, \mathrm{N}$-tetraacético

FAD: flavina adenina dinucleótido

Fc $\gamma R$ : receptores para la porción Fc de las inmunoglobulinas IgG

h: hora/s

HEPES: ácido N-(2-hidroxietil)piperacina-N'-2-etanosulfónico

Hsp: heat shock protein

IFN $\gamma$ : interferon gamma

Ig: inmunoglobulina

IL: interleucina

iNOS: óxido nítrico sintasa inducible

KDO: ácido 2-ceto-3-deoxioctónico

LB: medio de cultivo de Luria-Bertani

lípA/s: lípido/s A

L-NMA: $\mathrm{N}^{\mathrm{G}}$-metil-L-arginina

LPS/LPSs: lipopolisacárido/lipopolisacáridos min: minutos

MOPS: ácido 4-morfolinopropanosulfónico

MPO: mieloperoxidasa

NADH: nicotinamida adenina dinucleótido reducido

NADP: nicotinamida adenina dinucleótido fosfato

NADPH: nicotinamida adenina dinucleótido fosfato reducido 
NF- $\kappa B$ : nuclear factor of kappa B

NO: óxido nítrico

NOS: óxido nítrico sintasa

OCL: lípido que contiene ornitina

OMP: outer membrane proteins

pb: pares de bases

PBS: tampón fosfato salino

PMN: leucocitos polimorfonucleares neutrófilos

R-LPS: lipopolisacárido de cepas rugosas

RNI: intermediarios reactivos de nitrógeno

ROI: radicales intermediarios de oxígeno

SEM: error estándar de la media

SDS: dodecil sulfato sódico

S-LPS/s: lipopolisacárido/s de cepas lisas

SOD: superóxido dismutasa

sp: especies

TBE: tampón Tris-Borato-EDTA

TE: Tampón Tris-EDTA

TGF- $\beta$ : factor transformador del crecimiento $\beta$

TNF- $\alpha$ : factor de necrosis tumoral alfa

Tris: Tris-(hidroximetil)-aminometano

TTBS: tampón Tris salino con Tween-20

VIH: virus de la inmunodeficiencia humana 


\section{INTRODUCCIÓN}




\section{A. MECANISMOS DE DEFENSA ANTIMICROBIANA}

Las células fagocíticas constituyen uno de los principales mecanismos defensivos del organismo frente a las infecciones. Una vez que los microorganismos superan las defensas externas, los fagocitos actúan como la primera barrera defensiva celular que intenta limitar el progreso de la infección evitando la diseminación de los microorganismos. El fracaso de la respuesta fagocítica conlleva no sólo la progresión del proceso infeccioso, sino que en muchas ocasiones interviene de forma decisiva en la cronificación de la enfermedad. Esto es lo que sucede con los microorganismos intracelulares y en concreto con bacterias intracelulares facultativas como es el caso de las bacterias del género Brucella. El fracaso de los mecanismos bactericidas intracelulares frente a Brucella hace que el interior de los fagocitos constituya un nicho donde Brucella se puede desarrollar y multiplicar al abrigo del resto de los sistemas defensivos del organismo. Además, en esta ubicación intracelular, gran parte de los antimicrobianos son ineficaces, bien porque no puedan penetrar en el interior de la célula o bien porque su actividad se vea reducida por el efecto del $\mathrm{pH}$ o por la acción de las enzimas celulares. Algunas de las consecuencias inmediatas de la resistencia de Brucella a los mecanismos bactericidas de los fagocitos son, por tanto, la tendencia a la cronificación y el fracaso a los tratamientos antimicrobianos.

Así pues, el conocimiento de las interacciones Brucella-fagocito constituye un elemento fundamental en la explicación de la patogenia de la brucelosis.

\section{A.1. MECANISMOS FAGOCÍTICOS DE DEFENSA ANTIMICROBIANA}

\section{A.1.1. Marginación, quimiotaxis y migración}

Una vez producida la infección, los estímulos humorales de origen bacteriano (oligopéptidos $\mathrm{N}$-formilados) y los procedentes de la activación de los sistemas de vigilancia humorales (sistemas del complemento, de coagulación, etc.) y celulares (citocinas, productos de degradación) del organismo infectado inducen la estimulación 
de los fagocitos circulantes en la sangre y la aparición de moléculas de adhesión en las células endoteliales y fagocitos.

Los fagocitos se marginan dentro del vaso sanguíneo y se adhieren a las células endoteliales de los capilares adyacentes al tejido infectado, resultado de la interacción de receptores y ligandos presentes en ambos tipos de células ${ }^{(1)}$ entre los que se encuentran las selectinas L, P y E, diferentes integrinas como VLA-4, VLA-5, VLA-6, Mac-1 (CD11bCD18), LFA-1, y otras proteínas como la molécula de adhesión celular vascular (VCAM-1) y la molécula de adhesión intracelular (ICAM-1) ${ }^{(2)}$.

Una vez los fagocitos se han adherido, se produce la migración o extravasación a través de la pared capilar (diapédesis) ${ }^{(3)}$ dirigiéndose al foco inflamatorio o infeccioso siguiendo un gradiente de concentración de determinadas sustancias denominadas citotaxinas o factores quimiotácticos (quimiotaxis) ${ }^{(1)}$.

\section{A.1.2. Ingestión o fagocitosis}

El primer paso que se produce es la adherencia de la bacteria a la superficie del fagocito. La adherencia puede estar mediada por diferentes lectinas ${ }^{(4)}$ (presentes tanto en el microorganismo como en el fagocito), por receptores para la porción Fc de las IgG $(\mathrm{Fc} \gamma \mathrm{R})$, por receptores para factores del complemento (CR1, CR2 y CR4) y por receptores para el $\operatorname{LPS}^{(5)}$.

Una vez adherido el microorganismo a la superficie del fagocito el siguiente paso es la ingestión o internalización ${ }^{(1)}$. La membrana del fagocito se desplaza para rodear al microorganismo, a través de proyecciones denominadas pseudópodos. Este proceso se produce de forma secuencial (mecanismo de "cierre de cremallera") ${ }^{(1)}$, mediante la adhesión progresiva de los receptores presentes en la superficie de los fagocitos a los ligandos de la superficie bacteriana ${ }^{(6)}$, hecho que requiere movilidad de los receptores en la membrana del fagocito. Una vez el microorganismo está rodeado, los pseudópodos se encuentran y se funden las membranas por su polo distal ${ }^{(7)}$, quedando englobado en una vacuola denominada fagosoma ${ }^{(8)}$.

\section{A.1.3. Desgranulación, activación de los mecanismos bactericidas, muerte y digestión}

Tras la ingestión, los gránulos lisosomales primarios y secundarios de los fagocitos se fusionan con el fagosoma, descargando su contenido (desgranulación), formando el 
fagolisosoma $^{(6)}$. Una vez producida la fagocitosis se activan varios mecanismos antimicrobianos, que describiremos detalladamente a continuación ${ }^{(4)}$.

Tras la muerte del microorganismo, los fagocitos son capaces de digerirlo ${ }^{(1)}$ mediante enzimas hidrolíticas (proteasas, nucleasas, lipasas) presentes también en los lisosomas. Se forma finalmente un cuerpo residual, que contiene material no digerible que será descargado al exterior de la célula ${ }^{(8)}$.

\section{A.2. MECANISMOS BACTERICIDAS}

Los mecanismos bactericidas desarrollados por los fagocitos pueden clasificarse en función de su relación con el oxígeno molecular en mecanismos oxígeno dependientes y mecanismos oxígeno independientes.

\section{A.2.1. MECANISMOS OXÍGENO DEPENDIENTES}

El proceso de fagocitosis conduce a un incremento en el consumo de oxígeno, que al contrario de lo que se podría pensar, no se produce por un incremento de la actividad de la cadena transportadora de electrones de las mitocondrias para la generación de energía necesaria para la fagocitosis. Este aumento del consumo de oxígeno se produce por una nueva vía metabólica que ha recibido el nombre de estallido respiratorio o explosión oxidativa, ya que el consumo de $\mathrm{O}_{2}$ se produce de forma abrupta y se desvanece en 30 $\min ^{(1)}$. El proceso se inicia con la activación de un complejo enzimático formado tras la fusión de la membrana de los gránulos específicos con la de los fagosomas (que deriva de la membrana plasmática). Dicho complejo incluye la NADPH oxidasa de la membrana plasmática, caracterizada como una citocromo reductasa de la flavoproteína FAD. Esta se une a un citocromo b (único en la membrana de los gránulos específicos) y este complejo en presencia de una quinona reduce el $\mathrm{O}_{2}$ a superóxido ${ }^{(6 ; 9)}$.

Los equivalentes reductores que conducen al estallido respiratorio son proporcionados por el NADPH, el cual es oxidado a NADP por la NADPH oxidasa, siendo regenerado por dos reacciones redox que se producen gracias a la activación de la derivación de la vía hexosa monofosfato ${ }^{(1)}$ (vía de las pentosas fosfato ${ }^{(8)}$ ). Esta vía utiliza como sustrato la glucosa, cuyo consumo por tanto se ve incrementado, requiriendo de este modo el sistema NADPH oxidasa un suministro constante de glucosa y de oxígeno. 
Una vez producido el superóxido se producen diversas reacciones que van a conducir a la producción de una serie de radicales intermediarios de oxígeno (ROI), altamente reactivos y con actividad bactericida:

\section{A.2.1.1. Radical superóxido $\left(\mathrm{O}_{2}^{-}\right)$}

Es un compuesto moderadamente reactivo capaz de actuar como oxidante o como reductor en los sistemas biológicos y es el que tiene la vida más larga de todos los $\mathrm{ROI}^{(10)}$. Su relativa inactividad permite a $\mathrm{O}_{2}{ }^{-}$no sólo actuar en el fagolisosoma sino también difundir a considerables distancias donde accederá a dianas intracelulares vía canales celulares de aniones ${ }^{(11)}$. Estas dianas incluyen enzimas bacterianas, particularmente aquellas implicadas en la biosíntesis de aminoácidos ramificados, como por ejemplo $\alpha, \beta$-dihidroxiisovalerato dehidratasa y láctico deshidrogenasa ligada a $\mathrm{NADH}^{(12 ; 13)}$. Algunas dehidratasas de bacterias como Escherichia coli que contienen grupos (4Fe-4S) son particularmente susceptibles a la inactivación por $\mathrm{O}_{2}{ }^{-}$incluyendo aconitasa, 6-fosfogluconato dehidratasa, $\alpha, \beta$-dihidroxiácido dehidratasa y fumarasas $\mathrm{A}$ y $\mathrm{B}^{(14)}$. En ambientes de bajo $\mathrm{pH}$, como son los sitios de inflamación o el interior del fagosoma, el $\mathrm{O}_{2}{ }^{-}$llega a ser protonado para formar $\mathrm{HO}_{2}{ }^{\cdot}$ que por su carga neutra es más permeable, es un oxidante más potente ${ }^{(15)}$ y probablemente más reactivo consigo mismo para formar $\mathrm{H}_{2} \mathrm{O}_{2}$ (dismutación espontánea) ${ }^{(9)}$. $\mathrm{El} \mathrm{O}_{2}{ }^{-}$presenta toxicidad adicional mediante su participación en la reacción de Haber-Weiss en presencia de hierro catalíticamente activo.

\section{A.2.1.2. Peróxido de hidrógeno $\left(\mathrm{H}_{2} \mathrm{O}_{2}\right)$}

Se sintetiza a partir de dos radicales superóxido en una reacción catalizada por la superóxido dismutasa (SOD): $2 \mathrm{O}_{2}^{-}+2 \mathrm{H}^{+} \rightarrow \mathrm{H}_{2} \mathrm{O}_{2}+\mathrm{O}_{2}\left({ }^{1} \mathrm{O}_{2}\right)$. Es más reactivo que $\mathrm{O}_{2}^{-}$y rápidamente difunde a través de las membranas celulares. Entre las fuentes potenciales del daño celular mediado por $\mathrm{H}_{2} \mathrm{O}_{2}$ se incluyen la oxidación de membranas celulares y enzimas, daño del ADN y mutagénesis, e inhibición de procesos de transporte a través de la membrana ${ }^{(16)}$.

\section{A.2.1.3. Radical hidroxilo ( ${ }^{\circ} \mathrm{OH}$ )}

En muchos casos donde $\mathrm{O}_{2}^{-}$y/o $\mathrm{H}_{2} \mathrm{O}_{2}$ están implicados en el daño celular, no está claro si el proceso está mediado por ellos mismos o si simplemente sirven como precursores para otras especies oxidantes más potentes como es el radical hidroxilo 
$(\mathrm{OH})$ el cual sería verdaderamente el mediador del daño. Este radical hidroxilo se genera a través de la reacción de Haber-Weiss ${ }^{(17)}$ :

$$
\begin{aligned}
& \mathrm{H}_{2} \mathrm{O}_{2}+\mathrm{Fe}^{2+} \rightarrow \mathrm{OH}+\mathrm{OH}^{-}+\mathrm{Fe}^{3+} \text { (reacción de Fenton) } \\
& \mathrm{O}_{2}^{-}+\mathrm{Fe}^{3+} \rightarrow \mathrm{O}_{2}+\mathrm{Fe}^{2+} \text { (reducción del } \mathrm{Fe}^{3+} \text { cuando la concentración de Fe está }
\end{aligned}
$$
limitada)

$\mathrm{O}_{2}{ }^{-}+\mathrm{H}_{2} \mathrm{O}_{2} \rightarrow{ }^{\cdot} \mathrm{OH}+\mathrm{OH}^{-}+\mathrm{O}_{2}\left({ }^{1} \mathrm{O}_{2}\right)$ (reacción completa de Haber-Weiss)

La formación del radical hidroxilo bajo condiciones fisiológicas requiere la catálisis de un metal de transición, principalmente el hierro (pudiendo actuar también el $\mathrm{Cu}^{2+}$ $\left.{ }^{(18)}\right)$. La disponibilidad de hierro juega así un papel importante y complejo en las interacciones microorganismo-fagocito.

Debido a su alta reactividad, el $\mathrm{OH}$ tiene una difusión limitada y así debe ser generado en las proximidades de su diana celular. Es el oxidante más potente y reactivo de los ROI estando implicado en la oxidación de un gran número de biomoléculas. Provoca el entrecruzamiento de las proteínas a nivel de grupos sulfhidrilo, destruyendo la actividad de enzimas fundamentales (incluyendo bombas de iones dependientes de ATP). Daña el ADN, tanto nuclear como mitocondrial, al oxidar bases y producir la rotura de las hebras de $\mathrm{ADN}^{(19)}$.

A nivel de los lípidos, especialmente los de membrana, inicia el proceso de peroxidación lipídica. El radical hidroxilo extrae un átomo de hidrógeno del carbono $\alpha$ adyacente al doble enlace en los ácidos grasos insaturados (LH) de los fosfolípidos de membrana, dando lugar a un radical lipídico $\left(\mathrm{L}^{*}\right)$. Este reacciona con oxígeno para dar un radical peroxilo (LOO'), que a su vez puede reaccionar con otros lípidos para generar radicales lipídicos $\left(\mathrm{L}^{*}\right)$ adicionales, lo que conduce a una cascada de radicales libres, que afecta a la permeabilidad de la membrana ${ }^{(19 ; 20)}$.

\section{A.2.1.4. Singlete de oxígeno $\left({ }^{1} \mathrm{O}_{2}\right)$}

Es una forma de oxígeno molecular $\left(\mathrm{O}_{2}\right)$ de energía más elevada ${ }^{(10)}$. La absorción de energía eleva los dos electrones no pareados del oxígeno molecular a orbitales de mayor energía, pudiendo presentarse en dos formas, delta ${ }^{1} \Delta_{\mathrm{g}} \mathrm{O}_{2}$ y sigma ${ }^{1} \Sigma_{\mathrm{g}} \mathrm{O}_{2}$, según ocupen igual o diferentes orbitales ${ }^{(9)}$. Puede ser generado en varias reacciones como en la dismutación espontánea del $\mathrm{O}_{2}{ }^{-}$, en la reacción de Haber-Weiss, y durante la activación del sistema peroxidasa- $\mathrm{H}_{2} \mathrm{O}_{2}$-haluro ${ }^{(9)}$. 
Es un compuesto sumamente reactivo, y por tanto tóxico. En los sistemas biológicos microbianos puede originar una gran variedad de reacciones de oxidación que producen la destrucción de enzimas y componentes celulares vitales ${ }^{(10)}$.

\section{A.2.1.5. Sistema peroxidasa/ $\mathrm{H}_{2} \mathrm{O}_{2}$ /haluro}

Durante el proceso de desgranulación se vierten dentro del fagosoma diferentes enzimas, entre ellas, las peroxidasas: la mieloperoxidasa (MPO) contenida en los gránulos azurófilos de los neutrófilos PMN y en menor cantidad en los monocitos, y la eosinofilperoxidasa (EPO) presente en los eosinófilos ${ }^{(21)}$. Los macrófagos son incapaces de sintetizar esta enzima, si bien presentan restos de MPO de las células precursoras o bien pueden adquirirla por fagocitosis de la liberada por otros fagocitos adyacentes ${ }^{(22)}$. Son glicoproteínas catiónicas con un grupo prostético hemo que contiene hierro ${ }^{(14)}$. Estas enzimas en presencia de $\mathrm{H}_{2} \mathrm{O}_{2}$ y haluros (yoduro, cloruro, bromuro $\left(\mathrm{X}^{-}\right)$) catalizan la formación de ácidos hipohalosos: $\mathrm{H}_{2} \mathrm{O}_{2}+\mathrm{X}^{-} \rightarrow \mathrm{OX}^{-}+\mathrm{H}_{2} \mathrm{O}$. La concentración de cloruro en los fluidos biológicos es mayor que la de los otros haluros, sugiriendo que es el haluro preferentemente utilizado. Como consecuencia se forman diferentes agentes tóxicos ${ }^{(9)}$ :

- Acidos hipohalosos: son potentes oxidantes. Entre ellos el hipoclorito o ácido hipocloroso es uno de los más potentes agentes microbicidas.

- Halógenos: Cloro $\left(\mathrm{Ch}_{2}\right)$, bromo $\left(\mathrm{Br}_{2}\right)$ y yodo $\left(\mathrm{I}_{2}\right)$ se pueden formar por oxidación de los haluros, si bien la especie predominante con cloro y bromo es el ácido hipohaloso correspondiente. En el caso del yoduro es oxidado a $\mathrm{I}_{2}$ por la peroxidasa y el $\mathrm{H}_{2} \mathrm{O}_{2}$, siendo posteriormente reducido de nuevo a $\Gamma$ por reacción con un grupo sulfhidrilo de la superficie $\mathrm{u}$ otro grupo oxidable, amplificando el efecto bactericida.

- Cloraminas: El ácido hipocloroso puede reaccionar con compuestos que contengan nitrógeno, dando lugar a cloraminas que son tóxicas.

- Radicales hidroxilo: se ha propuesto su formación a través de la siguiente reacción:

$$
\mathrm{HOCl}+\mathrm{O}_{2}{ }^{-} \rightarrow \mathrm{C \Gamma}+\mathrm{O}_{2}+\mathrm{OH}
$$

- Singlete de oxígeno: formado en la reacción: $\mathrm{OC} \Gamma+\mathrm{H}_{2} \mathrm{O}_{2} \rightarrow{ }^{1} \mathrm{O}_{2}+\mathrm{C} \Gamma+\mathrm{H}_{2} \mathrm{O}$ 
Como consecuencia de la formación de todos estos productos, el sistema MPO/ $\mathrm{H}_{2} \mathrm{O}_{2}$ /haluro es uno de los sistemas bactericidas más potentes, provocando daño y muerte celular $^{(9)}$. Esta se produce por:

-Halogenación en la que el haluro es unido covalentemente a constituyentes del organismo ingerido. El yodo actúa por iodinación de los residuos de tirosina de las proteínas, de los ácidos grasos insaturados y de los grupos sulfhidrilo. El bromo se une a componentes de la superficie celular, y el cloro a los grupos amino terminales de péptidos y proteínas, produciendo la inactivación de enzimas o la desnaturalización de proteínas.

-Oxidación de distintos componentes microbianos esenciales. Así pueden producir la oxidación de grupos sulfhidrilo de diferentes enzimas o la oxidación de grupos prostéticos hierro-sulfuro, presentes en proteínas que forman parte de la cadena transportadora de electrones microbiana. También pueden oxidar a diferentes hemoproteínas y provocar la decarboxilación y desaminación oxidativa de proteínas, así como iniciar la peroxidación lipídica dañando la integridad de la membrana.

\section{A.2.2. MECANISMOS OXÍGENO INDEPENDIENTES}

En los gránulos lisosomales de los fagocitos encontramos una gran cantidad de sustancias que intervienen en los procesos microbicidas $\mathrm{O}_{2}$-independientes y en la digestión de los microorganismos ${ }^{(3)}$. Existen algunas diferencias entre los macrófagos y los neutrófilos. Los primeros presentan un menor número de gránulos lisosomales, no tienen MPO ni son capaces de sintetizarla, pero sin embargo continúan sintetizando otras proteínas antimicrobianas como la lisozima y las defensinas ${ }^{(23)}$. Existen dos tipos principales de gránulos lisosomales: los gránulos específicos o secundarios y los gránulos azurófilos o primarios.

Los gránulos específicos o secundarios se fusionan con los fagosomas ${ }^{(6)}$ y aportan entre otras sustancias la lisozima y la lactoferrina.

La lisozima también está presente en los gránulos primarios y actúa hidrolizando el peptidoglicano de la pared celular bacteriana. La lactoferrina: es una glicoproteína fijadora hierro y de este modo priva a la bacteria de este metal esencial ${ }^{(6)}$. También se ha propuesto que la lactoferrina podría contribuir a la actividad antimicrobiana estimulando la producción de radicales hidroxilo, como un donador de hierro ${ }^{(24)}$, pero 
parece que puede tanto incrementar como prevenir su formación según su nivel de saturación de hierro y disponibilidad de sales de hierro exógenas ${ }^{(25)}$.

Los gránulos azurófilos o primarios aportan entre otras sustancias bactericidas la catpsina $\mathrm{G}$ y los péptidos catiónicos.

La catepsina $\mathrm{G}$ es una proteasa similar a la quimiotripsina, activa a $\mathrm{pH}$ neutro, que actúa inhibiendo el consumo de oxígeno bacteriano y la síntesis de proteínas, ARN y $\mathrm{ADN}^{(26)}$.

Los gránulos azurófilos contienen varios péptidos catiónicos: la BPI (bactericidal/permeability increasing protein), proteínas catiónicas antimicrobianas (CAP 57 y CAP 37) y un conjunto de péptidos (32-34 aminoácidos) denominados defensinas. Estas han sido descritas en los neutrófilos humanos (HNP 1, 2 y 3) así como en los macrófagos alveolares de conejo (MCP 1 y 2) y en los granulocitos peritoneales de conejo (NP 1, 2, 3a, 3b, 4 y 5) ${ }^{(26)}$. Todas estas proteínas catiónicas son activas a pH neutro, siendo por tanto más eficaces durante la fase inicial de fusión fagolisosomal, momento en el que se produce un aumento transitorio del $\mathrm{pH}$ previo a la acidificación del fagolisosoma ${ }^{(4)}$. Estas sustancias cargadas positivamente interaccionan con las cargas negativas del LPS de las enterobacterias (ácido 2-ceto-3-deoxioctónico (KDO) y grupos fosfato no sustituidos del núcleo y lípido $\mathrm{A}^{(27)}$ ), desplazando los cationes

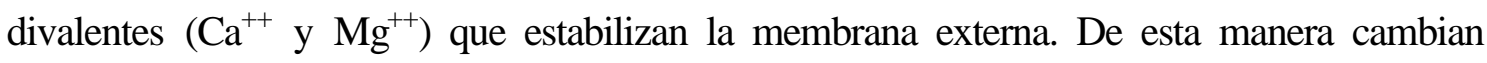
el orden de empaquetamiento del LPS y aumentan la permeabilidad de la membrana externa. Este aumento de la permeabilidad afecta a la del propio péptido catiónico, que de esta forma penetra en el interior de la bacteria, de ahí el nombre de vía de autopromoción ("self promoted uptake pathway") (28).

Además debemos considerar también entre estos mecanismos oxígeno independientes el descenso de $\mathrm{pH}$ intrafagolisosomal producido por el metabolismo glucolítico anaerobio de los fagocitos (formación de ácido láctico y ácidos grasos de cadena corta $)^{(6)}$, que tiene efecto inhibidor por sí solo y proporciona un ambiente en el que las enzimas hidrolíticas lisosomales actúan más efectivamente pues tiene un $\mathrm{pH}$ óptimo ácido ${ }^{(4 ; 29)}$. 


\section{A.3. EL ÓXIDO NÍTRICO}

El óxido nítrico (NO) es un gas de pequeño peso molecular $(30 \mathrm{Da})$, cuyas propiedades antimicrobianas se conocen desde la antigüedad. Los sumerios ya utilizaban el $\mathrm{NO}$ en el proceso de curación de las carnes para impedir el crecimiento del Clostridium botulinum $^{(30)}$. En 1818, Prout dio cuenta de grandes cantidades de nitrato en la orina de pacientes febriles ${ }^{(31)}$. Por otra parte, a finales del siglo XIX, la nitroglicerina comenzó a utilizarse en el tratamiento de las enfermedades coronarias. Pero no fue hasta la década pasada cuando una serie de descubrimientos, procedentes de diferentes líneas de investigación, revelaron que el NO realizaba una amplia gama de funciones, hasta el extremo de convertirlo en uno de los principales mensajeros biológicos. Así se descubrió que el NO era la molécula responsable de la vasodilatación producida por la acetilcolina en el endotelio y se identificó como el factor de relajación derivado del endotelio $(\mathrm{EDRF})^{(32)}$. También se demostró que participaba en distintas funciones fisiológicas y en la inflamación, que tenía propiedades antimicrobianas ${ }^{(33)}$ y antitumorales $^{(34)}$, y que estaba presente en las neuronas del cerebro ${ }^{(35 ; 36)}$, donde actuaba como mensajero $^{(37)}$.

\section{A.3.1. SÍNTESIS DE NO}

El NO es sintetizado a partir de L-arginina en dos reacciones sucesivas de tipo monooxigenasa catalizadas por una enzima denominada óxido nítrico sintasa (NOS). En este proceso un nitrógeno guanidino de la L-arginina es oxidado para producir la $\mathrm{N}^{\omega}$-OH-L-arginina como intermediario ${ }^{(38)}$, la cual es oxidada de nuevo para producir una molécula de NO y otra molécula de L-citrulina. En total, 1,5 moléculas de NADPH y 2 moléculas de $\mathrm{O}_{2}$, que actúan como cosustratos, se convierten en 1,5 moléculas de $\mathrm{NADP}^{+}$y 2 moléculas de $\mathrm{HO}$. Las NOS sólo producen NO cuando se unen formando dímeros. Además, cada subunidad necesita unirse a 5 cofactores: flavina adenina dinucleótido (FAD), flavina mononucleótido (FMN), calmodulina, grupo hemo y tetrahidrobiopterina $\left(\mathrm{BH}_{4}\right)^{(39)}$. Por tanto, en conjunto, se forma un complejo de $300 \mathrm{kDa}$ para sintetizar una molécula de $30 \mathrm{Da}$. 


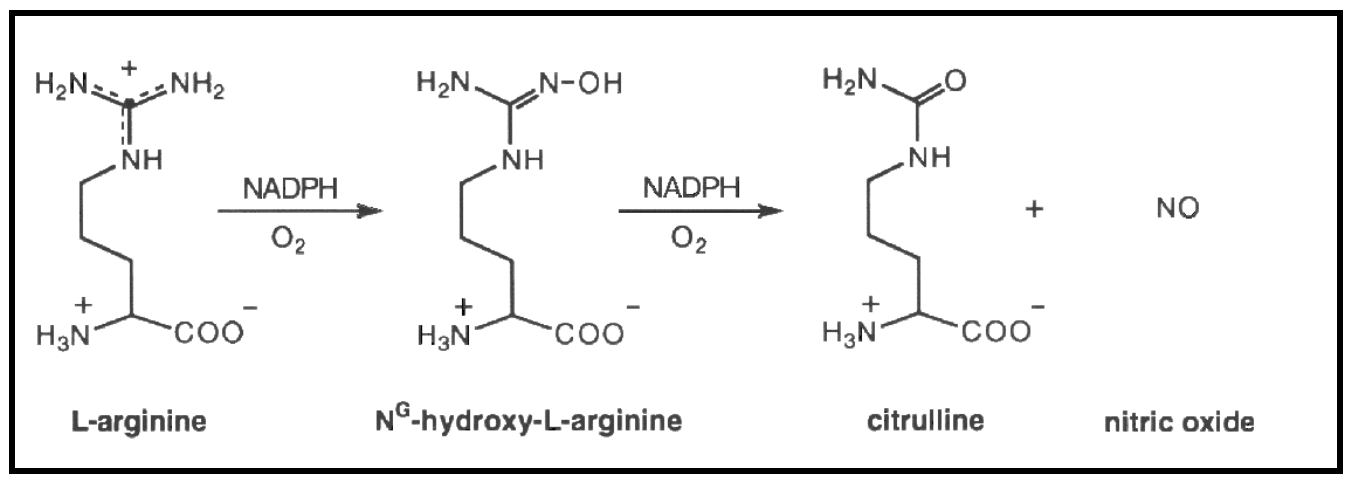

Figura 1. Síntesis de óxido nítrico a partir de L-arginina

Bajo condiciones fisiológicas el $\mathrm{NO}^{*}$ puede ser interconvertido en el catión nitrosonio $\left(\mathrm{NO}^{+}\right)$y el anión nitroxilo $\left(\mathrm{NO}^{-}\right)$. Además como resultado de la reacción del $\mathrm{NO}$ con los ROI y otras moléculas se produce una serie de compuestos denominados intermediarios reactivos de nitrógeno $(\mathrm{RNI})$ :

1.- Peroxinitrito $\left(\mathrm{OONO}^{-}\right)$. Se forma por la rápida interacción de $\mathrm{NO}^{`}$ y superóxido $\left(\mathrm{O}_{2}^{-}\right)^{(14)}$, aunque podría formarse también por la interacción del anión nitroxilo $\left(\mathrm{NO}^{-}\right)$y oxígeno, o también por la combinación de peróxido de hidrógeno y ácido nitroso $\left(\mathrm{HNO}_{2}\right)$. Éste podría existir en equilibrio con nitrito $\left(\mathrm{NO}_{2}{ }^{-}\right)$dentro del medio ácido del fagolisosoma $^{(40)}$.

2.- Dióxido de nitrógeno $\left(\mathrm{NO}_{2} \cdot\right.$ ). Puede ser formado por la autooxidación de $\mathrm{NO}$, o posiblemente por la oxidación de $\mathrm{NO}_{2}{ }^{-}$por mieloperoxidasa y $\mathrm{H}_{2} \mathrm{O}_{2}{ }^{(41)}$.

3.- S-nitrosotioles (RSNO). Formados por la reacción de $\mathrm{NO}^{\circ}$ con grupos tiol reducidos en presencia de un aceptor de electrones ${ }^{(42)}$.

4.- Existen otros productos como el trióxido dinitrógeno $\left(\mathrm{N}_{2} \mathrm{O}_{3}\right)$ y el tetraóxido dinitrógeno $\left(\mathrm{N}_{2} \mathrm{O}_{4}\right)$ que se producen por autooxidación de $\mathrm{NO}$. Otros derivados aparecen por la interacción de NO con tioles y hierro no hemo formando complejos de hierro-dinitrosil (DNIC).

\section{A.3.1.1. Tipos de NO sintasa}

Se han descrito 3 isoformas de la óxido nítrico sintasa (NOS) en los mamíferos que son la expresión de 3 genes diferentes. Esas isoformas son:

a) NOS neuronal (nNOS) o NOS1: fue la primera NOS en ser purificada y clonada a partir de neuronas de cerebelo de rata ${ }^{(43)}$; es citosólica y se expresa en cerebro, 
glándula adrenal, plaquetas, pulmón, células de músculo esquelético, neutrófilos y epitelio gastrointestinal entre otros.

b) NOS inducible (iNOS) o NOS2: enzima purificada y clonada por primera vez en macrófagos ${ }^{(44)}$; es citosólica y se expresa en un amplio espectro de células incluyendo neuronas y células endoteliales, hepatocitos, macrófagos, líneas celulares de carcinoma, neutrófilos, fibroblastos ${ }^{(45)}$, cuando es inducida por estímulos proinflamatorios como la endotoxina o las citocinas como el interferon gamma (IFN $\gamma$ ), la interleucina 1 beta (IL-1 $\beta$ ) o el factor de necrosis tumoral alfa (TNF $\alpha$ ).

c) NOS endotelial (eNOS) o NOS3: enzima purificada y clonada en células endoteliales $^{(46)}$, se expresa también en neuronas. Esta enzima se encuentra mayoritariamente en la membrana gracias a que presenta en el extremo $\mathrm{N}$-terminal una miristilación que le sirve para anclarse a la misma.

En líneas generales podemos distinguir dos grupos entre las sintasas de NO:

1.- NOS que se expresan de forma constitutiva en todos los tejidos en que están presentes, que son aquellas que dependen de elevaciones transitorias de calcio intracelular $\left(\left[\mathrm{Ca}^{2+}\right] \mathrm{i}\right)$ para activarse. A este grupo pertenecen la nNOS y eNOS. Estas enzimas producen $\mathrm{NO}$ en pequeñas cantidades y durante cortos periodos de tiempo. El NO producido por estas isoformas interviene en procesos fisiológicos como la neurotransmisión o la regulación de la presión sanguínea.

2.- En otro grupo aparte estaría la iNOS. Esta enzima se expresa de forma inducible. La diferencia más relevante de la iNOS con las otras isoformas de NOS es su fuerte asociación con la calmodulina ${ }^{(31)}$. Esto determina que sea activa a las concentraciones de $\left[\mathrm{Ca}^{2+}\right] \mathrm{i}$ que existen en la célula en reposo, lo que a su vez le permite estar activa de forma sostenida durante varios días. Se encuentra asociada a procesos inflamatorios o infecciosos $^{(47 ; 48)}$.

\section{A 3.1.2. Regulación de la iNOS}

La iNOS se activa por un gran número de citocinas y por productos microbianos, que varían con el tipo celular y con la especie y que con frecuencia actúan de forma sinérgica $^{(49)}$. Entre los productos bacterianos tenemos el lipopolisacárido de las bacterias gram negativas y el ácido lipoteicoico de los estreptococos del grupo viridans ${ }^{(40)}$. Entre las citocinas la principal activadora de la iNOS es el IFN $\gamma$, junto con otras como el TNF $\alpha$, la IL-1, la IL-2 ${ }^{(50)}$ o la IL-6 $6^{(51)}$. Existe sinergia en la estimulación de la expresión 
de la iNOS entre el TNF $\alpha$ y cualquiera de los $\mathrm{IFN}^{(49)}$, siendo de particular importancia pues la ingestión de los microorganismos determina la producción de ambas citocinas ${ }^{(52 ;}$ 53). Otra sinergia importante es la que presentan el LPS con el IFN $\gamma^{(54)}$ ya que el LPS es capaz de inducir la síntesis de TNF $\alpha$ y de IFN $\gamma$ por los macrófagos ${ }^{(31)}$.

\section{$\underline{\text { Regulación transcripcional }}$}

A la vez que se clonó la iNOS en macrófagos de ratón ${ }^{(54)}$, se demostró que se inducía transcripcionalmente por el IFN $\gamma$ y el LPS, aunque también podía influir un pequeño aumento en la estabilidad del ARNm. En el promotor de la iNOS de macrófagos murinos se encontraron dos regiones importantes en la activación transcripcional de este

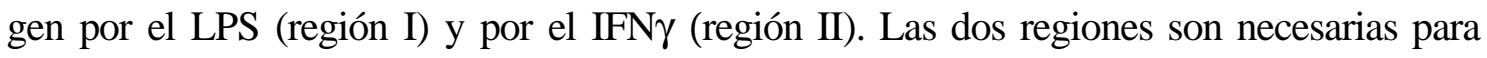
conseguir la máxima expresión de la iNOS. Sin embargo, mientras el LPS es capaz de inducir la expresión de iNOS por sí solo, el IFN $\gamma$ necesita la presencia del LPS para activar la transcripción. Los factores de transcripción que se han implicado más directamente en la inducción de la expresión de iNOS son: el factor de transcripción $\mathrm{NF}-\kappa \mathrm{B}$, para el LPS ${ }^{(55)}$, y el factor regulado por IFN $\gamma(\mathrm{IRF}-1)$, para el IFN $\gamma^{(56)}$.

No sólo se puede producir activación transcripcional, también se puede dar una inhibición transcripcional de la iNOS a través de distintos agentes como los glucocorticoides, IL-4 (la IL-4 también puede estimular la producción de NO bajo ciertas condiciones), IL-8, e IL-10 que actúan por mecanismos transcripcionales y posttranscripcionales ${ }^{(57)}$. Pero el inhibidor más potente es, sin duda, el factor transformador del crecimiento $\beta$ (TGF- $\beta$ ), del que hablaremos a continuación.

\section{$\underline{\text { Regulación post-transcripcional }}$}

El supresor más importante de la expresión de la iNOS es el TGF- $\beta 1^{(58)}$, y así pequeñas dosis de TGF- $\beta 1$ inhiben la inducción de iNOS por el LPS en $\operatorname{ratas}^{(59)}$. En estudios realizados in vitro en macrófagos peritoneales de ratón, el TGF- $\beta 1$ fue capaz de desestabilizar el ARNm de iNOS, retrasar la síntesis de la proteína iNOS y acelerar su degradación ${ }^{(58)}$.

\section{$\underline{\text { Regulación post-traduccional }}$}

Se puede producir a través de la disponibilidad de alguno de los cofactores de la NOS. Esto se ha demostrado en el caso del grupo hemo ${ }^{(60)}$ o de la $\mathrm{BH}_{4}{ }^{(61)}$. 


\section{A.3.2. NO Y MACRÓFAGOS HUMANOS}

Los estudios sobre la iNOS se han llevado a cabo, sobre todo, en macrófagos de roedores, rata o ratón, induciendo su expresión con estímulos proinflamatorios o con productos microbianos. También se ha demostrado la expresión de la iNOS en macrófagos de otras especies de vertebrados como caballo, oveja, cabra y vaca ${ }^{(31)}$.

En el hombre se ha comprobado la presencia de las tres isoformas de NOS en diferentes tipos celulares. En el caso concreto de la iNOS, se ha demostrado su presencia o se ha conseguido inducir su expresión entre otras células ${ }^{(62)}$ en hepatocitos, células epiteliales pigmentarias de la retina, células de adenocarcinoma, queratinocitos, células del epitelio respiratorio y macrófagos, si bien sobre estos últimos ha existido mucha controversia $^{(47)}$.

Por una parte está claro que la producción de NO está elevada en pacientes infectados o en pacientes que reciben citocinas proinflamatorias como quimioterapia auxiliar en el cáncer ${ }^{(63)}$, si bien es posible que este $\mathrm{NO}$ se origine en otras células diferentes a los macrófagos. Denis obtuvo la primera evidencia de producción de NO por los macrófagos humanos, al detectar nitrito en el medio de cultivo de macrófagos derivados de monocitos tratados con citocinas e infectados con micobacterias ${ }^{(64)}$. Muchos investigadores han encontrado que los macrófagos humanos de sujetos normales producen poco o nada $\mathrm{NO}$ en respuesta a estímulos in vitro que originan grandes cantidades de $\mathrm{NO}$ en macrófagos de origen murino ${ }^{(57)}$. Por el contrario otros investigadores han demostrado la producción de $\mathrm{NO}$ en cultivos de macrófagos y monocitos humanos sometidos a la acción combinada de diferentes estímulos. Así Testi et al. ${ }^{(65)}$ consiguen la inducción de NO por monocitos humanos tras entrecruzamiento del receptor CD69, un miembro de la familia de receptores transductores de señales, presente en las células natural killer ${ }^{(66)}$ y en los monocitos humanos.

También se ha conseguido la expresión de iNOS funcional por los macrófagos humanos tras la interacción del antígeno de superficie $\mathrm{CD} 23^{(67)}$ con diferentes moléculas. Este antígeno es el receptor de baja afinidad para IgE (FcERII/CD23), que en los humanos tiene dos isoformas, a y b. El CD23 es expresado en la superficie de varios tipos de células tras estimulación por diferentes citocinas. In vitro y en condiciones normales los monocitos humanos no expresan en su superficie el CD23b. Para su expresión in vitro los monocitos humanos requieren su activación por IL-4 e IFN $\gamma$, dos 
citocinas secretadas durante las fases tempranas de la respuesta inmune ${ }^{(68)}$. In vivo la expresión de CD23 ha sido observada en el transcurso de varias reacciones alérgicas y otras reacciones dependientes de IL-4, incluyendo algunas enfermedades infecciosas ${ }^{(69)}$. La interacción de CD23 con IgE, con inmunocompejos de $\operatorname{IgE}$ o con anticuerpos monoclonales antiCD23 en la superficie de monocitos y macrófagos humanos promueve la generación de varias citocinas y la activación de la transcripción, síntesis y activación de la $\operatorname{iNOS}^{(67)}$. Así pues, estos datos indican claramente que la expresión de iNOS funcional puede ser obtenida en macrófagos humanos y que está relacionada con la iniciación y desarrollo de respuestas inmunes e inflamatorias dependientes de $\operatorname{IgE}^{(57)}$. Estos resultados han sido observados recientemente en macrófagos de rata por Alonso et al. ${ }^{(70)}$ quienes muestran la inducción de la producción de NO tras estimulación del CD23 con inmunocomplejos de IgE y con un anticuerpo policlonal anti CD23. La activación del factor de transcripción NFKB por estimulación de CD23 ha sido mostrada en el mismo sistema celular por Bayón et al. ${ }^{(71)}$ lo que explica la activación transcripcional del gen de la iNOS y la producción de NO.

La mayor evidencia de la inducción de la producción de NO por los macrófagos humanos ha sido obtenida en los fagocitos mononucleares de pacientes con enfermedades infecciosas o inflamatorias ${ }^{(31)}$. Así se ha demostrado un incremento en la expresión de la proteína iNOS en pacientes con síndrome de distress respiratorio agudo, glomerulonefritis y artritis reumatoide ${ }^{(72)}$, así como también en pacientes con hepatitis alcohólica y enfermedad granulomatosa crónica ${ }^{(73)}$.

Anstey et al. ${ }^{(74)}$ encontraron una elevación de la expresión de la proteína iNOS en las células mononucleares circulantes de niños de una zona Tanzania donde la malaria es endémica y se correlacionó con el incremento en la producción sistémica de NO. Nicholson et al. ${ }^{(75)}$ encontraron un incremento relevante en la expresión de la enzima iNOS en macrófagos de pacientes con tuberculosis pulmonar activa, enzima que, por otra parte, es requerida para el control de esta misma enfermedad en los ratones ${ }^{(76)}$. Un informe incluso sugiere que la producción de NO por macrófagos obtenidos de pacientes con tuberculosis activa puede aproximarse a los niveles de producción por células murinas ${ }^{(77)}$, aunque esta observación requiere confirmación. Bukrinsky et al. ${ }^{(78)}$ informaron que los monocitos infectados por VIH y activados por lipopolisacárido o TNF- $\alpha$ mostraban una producción de NO incrementada y también se detectó ARNm de iNOS en tejido cerebral de pacientes con encefalitis avanzada producida por VIH. 
Tomando todo esto en consideración, el peso de la evidencia sugiere que la vía de alta producción de NO (iNOS) es expresada en los macrófagos humanos, pero las señales requeridas para la estimulación de este sistema son diferentes a las utilizadas en los sistemas celulares murinos ${ }^{(40 ; 79)}$.

Por último, también ha sido observada la producción de NO por neutrófilos humanos $^{(80 ; 81)}$.

\section{A.3.3. FUNCIONES DEL NO}

\section{A.3.3.1. Funciones fisiológicas}

Son muchas las funciones fisiológicas que se atribuyen al NO. A continuación, mostramos algunas de las más importantes:

a) Inhibición de la adhesión y de la agregación plaquetaria. En estas funciones el NO actúa por un mecanismo dependiente de guanosina-3',5'-monofosfato cíclico $(\mathrm{GMPc})^{(82)}$. Las prostaciclinas y el NO actúan sinérgicamente para inhibir la agregación de las plaquetas ${ }^{(83)}$, jugando un papel importante en la resistencia a la trombosis.

b) Regulación de la presión sanguínea. El NO producido por el endotelio reduce la presión sanguínea ${ }^{(84)}$ y produce un aumento del flujo sanguíneo. En ambos casos el NO actúa a través de la activación, por cambio estructural, de la guanilato ciclasa que determina la relajación de la musculatura lisa vascular. Es por tanto un vasodilatador endógeno y una reducción en su síntesis podría contribuir a la patogénesis de la hipertensión y otros desórdenes vasculares ${ }^{(85)}$.

c) Mensajero en el sistema nervioso central. El NO ha sido considerado como un nuevo neurotransmisor del sistema nervioso, aunque atípico, pues no se almacena en vesículas y no actúa a través de receptores ${ }^{(86)}$. La estimulación del receptor del glutamato, N-metil-D-aspartato (NMDA), en el cerebro, determina la liberación de $\mathrm{NO}^{(87)}$ convirtiéndolo en mediador del glutamato. A corto plazo desempeña un papel semejante al de los aminoácidos excitatorios y a largo plazo parece participar en la función de aprendizaje y memoria del cerebro ${ }^{(88)}$.

Además en los nervios periféricos también actúa como neurotransmisor mediando la neurotransmisión no adrenérgica no colinérgica ${ }^{(89)}$. También se ha comprobado que influye en la liberación de noradrenalina ${ }^{(90)}$ y en la secreción de catecolaminas ${ }^{(91)}$. 


\section{A.3.3.2. Funciones en el sistema inmune y en la inflamación.}

El NO forma parte de la inmunidad no específica, ejerciendo acciones citostáticas o citotóxicas frente a microorganismos y células tumorales. Pero el NO presenta la característica dualidad protectora/destructora inherente a los componentes principales del sistema inmune, pudiendo causar daño a los propios tejidos del huésped ${ }^{(31)}$.

El NO también actúa como modulador del sistema inmune. Así en grandes cantidades puede inhibir la producción de citocinas, pero en pequeñas cantidades puede inducirlas $^{(92)}$. La inhibición de la iNOS aumenta exageradamente la liberación de IFN $\gamma$ y TNF $\alpha$, lo cual causa un aumento de la mortalidad en el shock séptico ${ }^{(93)}$. El NO producido por células Th1 actúa como una molécula auto-reguladora, inhibiendo la producción de IL-2 e IFN $\gamma$. La IL-2 es un factor de crecimiento esencial para las células Th1 y CD8+, con lo que el NO actuaría impidiendo una superexpansión de dichas células $^{(94)}$. Del mismo modo el NO producido por los macrófagos puede inhibir la proliferación de los linfocitos T que se produce durante la respuesta inmune celular ${ }^{(95)}$.

En las células presentadoras de antígeno el NO puede inhibir la síntesis del complejo mayor de histocompatibilidad (MHC) de clase II, como ocurre en los macrófagos peritoneales $^{(96 ; 97)}$. Del mismo modo la estimulación de los macrófagos alveolares por TNF $\alpha$ inhibe la síntesis y expresión del complejo MHC de clase II vía generación de $\mathrm{NO}^{(96)}$.

El NO inhibe la adherencia de los neutrófilos y su producción de $\mathrm{O}_{2}{ }^{-}$por inhibición de la NADPH oxidasa ${ }^{(98)}$. En los macrófagos peritoneales la generación de NO inhibe la síntesis de proteínas, la fagocitosis y la explosión oxidativa ${ }^{(96 ; 97)}$. También es capaz de inhibir la liberación de histamina o del factor activador de plaquetas (PAF) desde los $\operatorname{mastocitos}^{(99 ; 100)}$.

El NO también puede inhibir la activación transcripcional de varios genes, entre ellos la $\operatorname{iNOS}^{(101 ; 102)}$. En linfocitos B, la presencia de bajas concentraciones de NO (en el rango $\mu \mathrm{M}$ ), pero mantenidas a lo largo del tiempo, previenen la apoptosis o muerte celular programada inducida por TGF- $\beta^{(103)}$. Sin embargo, el NO puede producir apoptosis en macrófagos peritoneales y en células RAW $264.7^{(104)}$.

El NO es un mediador proinflamatorio ${ }^{(105)}$ presentando también en la inflamación un papel dual, beneficioso/perjudicial, deducido de estudios en ratones iNOS "knockout" ${ }^{(106)}$. Por un lado tiene un papel perjudicial pues participa en la hipotensión y el daño pulmonar inducido por el LPS, en el daño hepático inducido por el shock hemorrágico, 
activa factores de transcripción proinflamatorios, interviene en la vasculitis autoinmune, en el infarto cerebrovascular y en el rechazo agudo de trasplantes. Por otro lado tiene un papel beneficioso disminuyendo la marginación y activación de neutrófilos inducida por LPS o favoreciendo la vascularización y cicatrización de heridas.

\section{A.3.4. FUNCIONES ANTIMICROBIANAS}

\section{A.3.4.1. Evidencias de la actividad antimicrobiana del NO}

La actividad antimicrobiana del óxido nítrico ha sido demostrada por una variedad de aproximaciones:

\section{1.- Producción como respuesta del huésped a la infección}

La producción de NO por la iNOS es estimulada por citocinas proinflamatorias como IFN- $\gamma$, TNF- $\alpha$, IL-1 e IL-2, así como por productos microbianos ${ }^{(40)}$ como el lipopolisacárido de las bacterias gram negativas (el más estudiado), el ácido lipoteicoico de los estreptococos viridans $^{(107)}$ o del Staphylococcus aureus ${ }^{(108)}$, las porinas de $Y$. enterocolitica $^{(109)}$ y también la toxina-1 del síndrome del shock tóxico ${ }^{(108)}$. Las infecciones en humanos y animales de experimentación están a menudo asociadas con un incremento significativo en la producción sistémica de $\mathrm{NO}^{(74 ; 110 ; 111)}$ y se ha demostrado incremento en la expresión de iNOS y producción de NO en los sitios de infección, tanto en modelos animales como en el caso de la toxoplasmosis y leishmaniasis, como en infecciones humanas como la tuberculosis ${ }^{(75 ; 112)}$. La expresión de iNOS se ha demostrado asociada a la resistencia a distintos microorganismos como las micobacterias, los hongos Histoplasma capsulatum y Criptococcus neoformans y protozoos como Leishmania major ${ }^{(31)}$.

\section{2.- Exacerbación de la infección por los inhibidores de la NOS}

Existe una correlación entre la producción de NO en muchos modelos animales con la capacidad del huésped de contener la proliferación microbiana, pues la inhibición de la actividad de la iNOS produce un gran incremento en la carga microbiana ${ }^{(76 ; 112)}$. Así existen numerosos estudios in vivo en los que la utilización de inhibidores competitivos de la NOS $\left(\mathrm{N}^{\mathrm{G}}\right.$-metil-L-arginina (L-NMA), aminoguanidino, $\mathrm{N}^{6}$-(1-iminoetil)-L-Lisina o $\mathrm{N}^{\mathrm{G}}$-nitro-L-arginina metil éster) ha demostrado empeorar el curso de numerosas infecciones con un efecto perjudicial para el huésped ${ }^{(31)}$. Entre ellas destacan las infecciones por Listeria monocitogenes, Mycobacterium tuberculosis, Brucella suis ${ }^{(113)}$, Criptococcus neoformans, Leishmania major, Trypanosoma cruzi, Schistosoma 
mansoni, Toxoplasma gondii, virus coxsackie y Sindbis virus. La inhibición de la vía de alta producción de NO en los macrófagos presumiblemente contribuye a este efecto perjudicial, pues muchos de estos patógenos son captados por los macrófagos in vivo y son susceptibles de la inhibición por los mismos in vitro ${ }^{(50 ; 51)}$. En contraposición existen algunas infecciones en las que la administración de inhibidores de NOS supone un efecto beneficioso para el huésped como en infecciones por Tick-borne encephalitis virus, influenza virus o Trypanosoma brucei, y otras en las que tiene ambos efectos como es el caso de la listeriosis ${ }^{(114 ; 115)}$.

\section{3.- Acción antimicrobiana del NO exógeno}

La acción directa del NO como agente capaz de inhibir o matar a los microorganismos ha sido demostrada en mucho estudios ${ }^{(31)}$, en los que administrando in vitro distintos compuesto donadores de NO directamente sobre los microorganismos, son capaces de inhibirlos o matarlos (tabla 1).

Tabla 1. Efecto de NO en el crecimiento de microorganismos patógenos

\begin{tabular}{|c|c|}
\hline AGENTE & "MICROORGANISMO INHIBIDO \\
\hline NO gas & L. major, T. musculi \\
\hline Aductos nucleófilos-NO & S. typhimurium \\
\hline $\begin{array}{l}\mathrm{NaNO}_{2}+\mathrm{H}^{+} \text {(formación de ácido nitroso que dismuta } \\
\text { a NO) }\end{array}$ & $\begin{array}{l}\text { Pseudomonas, Clostridium, } \text { S. aureus, } \\
\text { L. enriettii, } \text { M. bovis, } M . \text { tuberculosis, } \\
\text { M. avium, M. intracelulare }\end{array}$ \\
\hline S-nitrosocisteína & $\begin{array}{c}\text { S. enteritidis, S. anatum, S. cholerasuis, } \\
\text { E. faecium, } \\
\text { C. sporogenes, C. perfringens, P. falciparum }\end{array}$ \\
\hline $\begin{array}{l}\text { S-nitroso-N-acetil-L-penicilamina (SNAP) } \\
\text { (SNAP añadido a células infectadas transformándolas } \\
\text { en virustáticas) }\end{array}$ & $\begin{array}{c}\text { poxvirus (ectromelia, vaccinia), } \\
\text { herpesvirus (HSV-1 y EBV-1) } \\
\text { rabdovirus (VSV), retrovirus (Friend leukemia } \\
\text { virus) }\end{array}$ \\
\hline $\begin{array}{l}\text { Fuente de } \mathrm{NO} \quad \text { (nitrito ácido o donador) en } \\
\text { combinación con } \mathrm{H}_{2} \mathrm{O}_{2} \text { (formación de peroxinitrito) }\end{array}$ & E. coli \\
\hline $\begin{array}{l}\begin{array}{l}\text { 3-morfolino-sidnonimina } \\
\text { peroxinitrito) }\end{array} \\
\text { (SIN-1) }\end{array}$ & $\begin{array}{l}\text { Brucella suis, E. coli, S. typhimurium, } \\
\text { Virus Friend leucemia }\end{array}$ \\
\hline
\end{tabular}

\section{4.- Expresión de genes relacionados con la resistencia a NO}

Se ha encontrado una correlación entre la resistencia microbiana y la expresión de genes cuyos productos resisten o reparan el daño dependiente de NO.

\section{5.- Estudios con ratones iNOS-deficientes (iNOS knock-out)}

Empleando estos ratones deficientes se ha comprobado la diferente contribución de iNOS a la defensa del huésped dependiendo del tipo de infección. Así tenemos diferentes papeles de la expresión de la iNOS. 
Se ha demostrado un papel beneficioso y esencial para la supervivencia del huésped en las infecciones producidas por Mycobacterium tuberculosis ${ }^{(76)}$, Leishmania major, virus Ectromelia (agente de mousepox) ${ }^{(106)}$. En otros casos como con Listeria monocytogenes $^{(116 ; 117)}$ o Toxoplasma gondii $^{(118)}$ presenta un papel beneficioso pero no dominante.

También puede tener un papel perjudicial para el huésped. Es el caso del virus influenza $\mathrm{A}^{(119)}$. La infección del ratón con el virus influenza A produce un fenómeno inflamatorio al cual contribuiría la iNOS y que parece la causa más importante de la mortalidad. En el caso de Mycobacterium avium $^{(120)}$ parece que la acción de la iNOS es la inmunosupresión.

Por último en algunas infecciones juega un papel imperceptible ya que su evolución no se ve afectada por la deficiencia de iNOS. En este caso están las infecciones por, Pseudomonas aeruginosa, Legionella pneumophila Chlamydia trachomatis, Trypanosoma cruzi, Plasmodium chabaudi y Plamodium yoelii.

\section{A.3.4.2. Mecanismos de acción antimicrobiana de los RNI}

Al ser el NO una molécula no polar, no cargada y de pequeño tamaño atraviesa las membranas rápidamente, al igual que el peroxinitrito, que lo hace probablemente como ácido hiponitroso (HOONO), o el S-nitrosoglutation que es captado activamente por Salmonella typhimurium ${ }^{(121)}$.

Se ha visto que los RNI ejercen sus acciones antimicrobianas modificando proteínas, ADN y lípidos, así como ejerciendo acciones indirectas mediante modulación de la respuesta inmune. Las proteínas que contienen metales y grupos tiol son sus dianas principales $^{(122)}$.

Los RNI actúan inactivando enzimas metabólicas claves que contienen grupos Fe-S en sus sitios catalíticos. Entre ellas están las enzimas del ciclo de Krebs como la aconitasa que es inactivada por $\mathrm{OONO}^{-(123)}$ y enzimas mitocondriales de la cadena transportadora de electrones como las NADH y succinato ubiquinona reductasas ${ }^{(50 ; 122)}$. El NO interacciona con distintas hemoproteínas, que cuando utilizan el grupo prostético en la catálisis, son inhibidas, como ocurre con la catalasa y distintos sistemas citocromo $^{(122 ; 124)}$.

Los RNI interaccionan con proteínas que contienen grupos tiol, mediante la $\mathrm{S}$-nitrosilación o transferencia de $\mathrm{NO}^{+}$a grupos sulfhidrilo. Los S-nitrosotioles, $\mathrm{N}_{2} \mathrm{O}_{3}$ y 
complejos dinitrosil-tiol-hierro son potentes agentes nitrosantes y pueden regular la función de distintas proteínas como el activador de plasminógeno tisular, las proteínas G, y otras proteínas presentes en diferentes sistemas humorales y celulares. También pueden inhibir numerosas enzimas presentes en las células fagocíticas como la catepsina $\mathrm{G}$, aldolasa, actina y la NADPH-oxidasa, que al limitar la producción de $\mathrm{O}_{2}{ }^{-}$disminuye el daño en los lugares de inflamación ${ }^{(122)}$. Sin embargo las dianas críticas con grupos tiol implicadas en los efectos antimicrobianos del NO son todavía desconocidas ${ }^{(40)}$.

El peroxinitrito puede producir modificaciones covalentes (N-nitrosilación) de residuos de tirosina ${ }^{(125)}$ y ha sido implicado en la defensa frente a S. typhimurium ${ }^{(126)}$.

El ADN también es una diana importante de los RNI. El NO puede deaminar el $\mathrm{ADN}^{(127)}$ vía un intermediario $\mathrm{N}$-nitrosante (quizás $\mathrm{N}_{2} \mathrm{O}_{3}$ ). El $\mathrm{NO}_{2}$. y el peroxinitrito dañan el ADN oxidándolo ${ }^{(128)}$. El NO es capaz de activar los factores de transcripción $\mathrm{AP}-1^{(129)}$ y NF- $\mathrm{KB}^{(130)}$. Además los RNI pueden interaccionar con los sistemas de reparación del $\mathrm{ADN}$ o con enzimas esenciales para su síntesis, como la ribonucleótido reductasa, la cual ha sido implicada como diana principal del NO en células tumorales $^{(131)}$ y en la capacidad del NO de inhibir virus vaccinia ${ }^{(132)}$.

Al actuar sobre lípidos puede producir daño a la membrana mediante peroxidación lipídica mediada por peroxinitrito ${ }^{(133)}$ y $\mathrm{NO}_{2}{ }^{(134)}$, si bien su relación con la actividad antimicrobiana es todavía desconocida.

\section{Interacción ROI-RNI}

La producción de NO puede simultáneamente incrementar la acción antimicrobiana de la explosión oxidativa y proteger a los tejidos del daño oxidativo ${ }^{(135)}$. Así productos como el peroxinitrito tiene un potencial citotóxico mayor que el $\mathrm{NO}$ o el ${ }^{\circ} \mathrm{O}_{2}{ }^{-}$solos. $\mathrm{La}$ combinación $\mathrm{H}_{2} \mathrm{O}_{2}$ y $\mathrm{NO}$ origina una potente actividad antibacteriana, posiblemente como resultado de la formación del radical hidroxilo $(\mathrm{OH})$ en presencia de hierro o por la generación de singlete de oxígeno $\left.{ }^{1} \mathrm{O}_{2}\right)^{(136 ; 137)}$. El NO también es capaz de reducir complejos de $\mathrm{Fe}^{\mathrm{III}(138)}$ propocionando un mecanismo para el incremento de la reacción de Haber-Weiss catalizada por $\mathrm{Fe}^{\mathrm{II}}$. Además el NO puede inhibir metaloenzimas antioxidantes como la catalasa ${ }^{(124 ; 135)}$, evitando su acción sobre el $\mathrm{H}_{2} \mathrm{O}_{2}$.

Por otra parte el NO puede proteger del daño oxidativo quizás formando complejos Fe-nitrosil, haciendo al $\mathrm{Fe}$ menos disponible para la catálisis de reacciones oxidativas. También puede actuar como protector de la oxidación inhibiendo la oxidasa de la explosión respiratoria ${ }^{(139)}$, sustrayendo radicales como $\mathrm{OH}^{(140)}$, induciendo la expresión 
de regulones protectores de estrés ${ }^{(141 ; 142)}$ o finalizando las reacciones de peroxidación lipídica de la membrana ${ }^{(138)}$.

\section{A.3.4.3. Defensas microbianas frente al NO}

Las defensas microbianas frente al estrés oxidativo o nitrosante comparten muchos elementos. Los principales mecanismos de evasión de los microorganismos frente al NO son:

1.- Moléculas de bajo peso molecular con grupos tiol. Entre ellas se encuentran el glutation, el micotiol y la homocisteína.

El glutation permite explicar la resistencia de las bacterias entéricas a los RNI pues contienen altas concentraciones de glutation, y la susceptibilidad de Staphylococcus spp. a los RNI, que por el contrario contienen bajas concentraciones del mismo ${ }^{(143 ; 144)}$.

El micotiol presente en las micobacterias y otros actinomicetales ${ }^{(144)}$ y tripanothione, un análogo tiol presente en trypanosomas y Leishmania spp. ${ }^{(145)}$ podrían representar un papel de resistencia.

La homocisteína está implicada en la resistencia a S-nitrosotioles $(S$. typhimurium $)^{(146)}$.

2.- Expresión de genes que confieren resistencia a oxidantes (inducción de síntesis de enzimas con función protectora) como el regulón soxRS y el regulón $o x y R$.

El regulón soxRS que inicialmente fue identificado como un sistema multigénico inducido por elevadas concentraciones de $\mathrm{O}_{2}{ }^{-(147)}$, puede ser inducido por $\mathrm{NO}^{(121)}$. Este regulón incluye genes que codifican para la glucosa-6-fosfato deshidrogenasa, para la manganeso-superóxido dismutasa (MnSOD) y para la endonucleasa IV, las cuales pueden contribuir a la defensa frente a RNI por generación de equivalentes reductores, reducción de la formación de peroxinitrito y reparación del ADN respectivamente.

El regulón oxyR que fue inicialmente descrito como un sistema genético inducido por $\mathrm{H}_{2} \mathrm{O}_{2}{ }^{(148)}$, puede ser inducido por peroxinitrito ${ }^{(149)}$. Contiene genes que codifican para la catalasa, la alkil hidroperóxido reductasa y la glutation reductasa.

3.- Otros mecanismos de defensa son: la exonucleasa RecBCD que interviene en los procesos de reparación del ADN y confiere resistencia a compuestos donadores de $\mathrm{NO}^{(150)}$; la $\mathrm{Cu}-\mathrm{ZN}$-superóxido dismutasa con igual función que la Mn-SOD; las mutaciones en el sistema específico de transporte de péptidos, que confiere a Salmonella resistencia a los S-nitrosotioles ${ }^{(150)}$; la piocianina de Pseudomonas 
aeruginosa que inhibe al NO in vitro ${ }^{(151)}$ o el pigmento hemozoína, producido por Plasmodium spp., que contiene un grupo hemo e inhibe la producción de $\mathrm{NO}^{(152)}$.

\section{B. BRUCELLA}

El género Brucella está incluido en el grupo 4, bacilos y cocos aerobios/microaerófilos Gram negativos, del Bergey's Manual of Determinative Bacteriology ${ }^{(153)}$. Se trata de pequeños bacilos o cocobacilos gram negativos, inmóviles, catalasa positivos, aerobios, si bien muchas cepas requieren $\mathrm{CO}_{2}$ para su crecimiento. Quimiorganotrofos nutricionalmente exigentes, poseen un metabolismo respiratorio con un sistema de transporte de electrones basado en citocromos y con oxígeno o nitrato como últimos aceptores de los mismos. Con un crecimiento lento y una temperatura óptima de $37^{\circ} \mathrm{C}$, producen en medios sólidos claros colonias pequeñas, lisas, convexas de color miel pálido, pudiendo aparecer variantes rugosas de las cepas lisas, existiendo también especies rugosas estables ${ }^{(154)}$.

Las brucelas constituyen un grupo genéticamente homogéneo de bacterias según los estudios de hibridación de ADN, y basados en estudios de secuencias del ARNr 16S, están filogenéticamente relacionadas con la subdivisión $\alpha 2$ de las Proteobacterias.

En la actualidad se incluyen en el género Brucella seis especies con diversos biotipos diferenciadas fundamentalmente por su sensibilidad a fagos, metabolismo oxidativo y sus huéspedes animales preferentes:

\begin{tabular}{|c|c|c|}
\hline ESPECIE & BIOTIPOS(btp) & HUÉSPED PREFERENTE \\
\hline B. melitensis & $1,2,3$ & cabras, ovejas \\
B. abortus & $1,2,3,4,5,6,7,9$ & bóvidos \\
B. suis & $1,2,3,4$ & cerdos, liebres(btp2), renos(btp4) \\
B. neotomae & & Neotoma lepida \\
B. ovis & & ovejas \\
B. canis & & perros \\
\hline
\end{tabular}

Las brucelas son parásitos intracelulares facultativos, que producen infecciones en un amplio espectro de mamíferos y en humanos, con una distribución prácticamente mundial $^{(155)}$. En los animales las brucelas producen una infección crónica o con gran tendencia a la cronicidad. En contraste, las brucelas no producen infecciones crónicas en 
ratones, los cuales presentan una bacteriemia transitoria al final de la cual eliminan la bacteria. En el hombre la infección por Brucella se caracteriza por su larga evolución y tendencia a la cronificación. A menudo se producen linfadenopatías locales, con posterior invasión del torrente circulatorio y diseminación. Se localizan principalmente en el sistema retículo endotelial donde la bacteria se desarrolla intracelularmente dentro de los fagocitos mononucleares gracias a la capacidad de las brucelas de resistir los mecanismos de muerte intracelular.

Así pues una de las principales características de las infecciones producidas por Brucella y que explica en gran medida la patogenia de la enfermedad es la capacidad de Brucella para sobrevivir y multiplicarse en el interior de las células fagocíticas ${ }^{(156)}$.

\section{B.1. MECANISMOS DE Brucella PARA EVADIR LAS DEFENSAS}

La destrucción intracelular de microorganismos por células fagocíticas depende de numerosos mecanismos, los cuales son susceptibles de alteración por los patógenos bacterianos $^{(157)}$. Nuestro conocimiento actual sobre la capacidad de Brucella para evitar dichos mecanismos es limitado ${ }^{(156)}$, siendo un proceso complejo, todavía no bien entendido.

\section{B.1.1. FAGOCITOSIS}

Existen diferentes estudios que proporcionan evidencia de que las brucelas no eluden la fagocitosis ${ }^{(157)}$. Las brucelas no poseen cápsulas antifagocíticas, sino que han desarrollado mecanismos de adhesión a las células. Las brucelas se adhieren a células polimorfonucleares y mononucleares no activadas y esta adherencia es mediada por interacciones tipo-lectina y estabilizada por lípidos bacterianos como el lípido que contiene ornitina (OCL). Al igual que sucede con otras bacterias, Brucella se puede adherir a proteínas con afinidad por azúcares (lectinas) presentes en los polimorfonucleares y macrófagos, a través del 1,2 glucano cíclico periplásmico y OCL $^{(158)}$. La bacteria adsorbida promueve su internalización. También se ha identificado una lectina en la superficie de Brucella que mediaría la adhesión a linfocitos y podría estar relacionada con la patogenicidad para el hombre, pues es mínima en $B$. neotomae y B. suis $^{(159)}$. De este modo las cepas lisas y rugosas de B. abortus son rápidamente ingeridas por neutrófilos humanos y de cobaya ${ }^{(160)}$, y 
también por leucocitos polimorfonucleares bovinos ${ }^{(161 ; 162)}$. Sin embargo, la eficacia de este mecanismo de internalización y su significado fisiológico está por determinar. Por otra parte, es bien conocido que la opsonización de células bacterianas incrementa la fagocitosis. Estudios de las interacciones entre macrófagos bovinos de glándula mamaria y cepas lisas y rugosas de $B$. abortus sugieren que ambas cepas son rápidamente ingeridas si están opsonizadas con complemento o anticuerpos específicos $^{(163)}$. Estos resultados coinciden con los realizados en neutrófilos humanos $^{(164)}$ y en macrófagos de conejos inmunizados con Rev.1 ${ }^{(163)}$.

\section{B.1.2. DESGRANULACIÓN}

Algunos autores proponen que la supervivencia es debida a un fallo en la desgranulación ${ }^{(164)}$. Riley and Robertson y Robertson et al. ${ }^{(161 ; 162)}$ examinaron los efectos de cepas lisas y rugosas de B. abortus sobre la desgranulación de gránulos primarios y secundarios en neutrófilos humanos o bovinos, observando que el grado de desgranulación estaba significativamente reducido cuando se incubaban con las brucelas, en comparación a las preparaciones control de neutrófilos incubados con el organismo extracelular Staphylococcus epidermidis. Los neutrófilos incubados con B. abortus liberaban significativamente menos mieloperoxidasa, y no existían diferencias en el grado de desgranulación de los neutrófilos incubados con la cepa lisa y los incubados con la cepa rugosa; la desgranulación también se inhibía con brucelas no viables. Del mismo modo los neutrófilos polimorfonucleares humanos incubados con B. melitensis $16 \mathrm{M}$ presentan una desgranulación y una actividad mieloperoxidasa inferior a la de los neutrófilos incubados con Staphylococcus aureus ${ }^{(165)}$.

Una evidencia indirecta de la inhibición de la desgranulación fue obtenida de los estudios de B. abortus (cepa 2308) viva o muerta por calor, sobre la actividad de iodinación de proteínas (una medida de la actividad MPO- $\mathrm{H}_{2} \mathrm{O}_{2}$-haluro) de los neutrófilos bovinos ${ }^{(166)}$. Esta actividad estaba significativamente suprimida, tanto en presencia de bacterias viables como muertas.

Bertram et al. ${ }^{(167)}$ encuentran que la desgranulación, preferencialmente de gránulos primarios, y como consecuencia el sistema bactericida mieloperoxidasa- $\mathrm{H}_{2} \mathrm{O}_{2}$-haluro, estaba inhibida por materiales nucleotídicos de bajo peso molecular producidos por Brucella y que fueron identificados y caracterizados por Canning et al. ${ }^{(166 ; 168)}$ como 5 'guanosina monofosfato (5'GMP) y adenina. Sin embargo ${ }^{(5)}$ parece poco probable que 
Brucella libere en condiciones fisiológicas concentraciones tan elevadas de 5'GMP y adenina como las utilizadas por estos autores.

Pizarro-Cerdá et al. ${ }^{(169)}$ también demuestran que la cepa 2308 de B. abortus (virulenta) previene la fusión fagosoma-lisosoma y que se distribuye en la región perinuclear dentro de compartimentos similares a autofagosomas

Ahora bien en cualquier caso la inhibición de la desgranulación es parcial luego deben existir otros mecanismos que permitan a Brucella resistir a la acción bactericida de los fagocitos.

\section{B.1.3. MECANISMOS BACTERICIDAS O$_{2}$-DEPENDIENTES}

La explosión oxidativa juega un papel fundamental en la activación de los mecanismos bactericidas $\mathrm{O}_{2}$-dependientes ${ }^{(5)}$. Estudios iniciales en neutrófilos bovinos indican que la ingestión de B. abortus no opsonizada (cepa 544), no induce la producción de $\mathrm{O}_{2}{ }^{-}$medido como reducción cuantitativa del colorante nitroazul de tetrazolio ${ }^{(170)}$. Experimentos posteriores realizados por Kreutzer et al. ${ }^{(160)}$ mostraron que la ingestión de cepas lisas y rugosas de B. abortus no parece estimular la actividad (medida como oxidación de la glucosa) de la vía de las pentosas monofosfato por neutrófilos humanos, ni tampoco la explosión oxidativa, pudiendo considerar que estos hechos comprometiesen la capacidad bactericida de los neutrófilos y determinasen la mayor supervivencia intracelular de B. abortus.

Sin embargo es importante notar que las bacterias utilizadas en estos estudios no estaban opsonizadas. Así las brucelas opsonizadas por un antisuero fresco (conteniendo anticuerpos antibrucela) o inactivado por calor (presumiblemente libre de la actividad del complemento) son capaces de estimular niveles significativos de producción de $\mathrm{O}_{2}{ }^{-}$ y de aumentar la actividad del sistema MPO- $\mathrm{H}_{2} \mathrm{O}_{2}$-haluro ${ }^{(171)}$ en neutrófilos bovinos y en macrófagos de la glándula mamaria de la vaca ${ }^{(163)}$. De igual manera Brucella sólo induce la explosión oxidativa en los PMN y monocitos humanos si previamente ha sido opsonizada con IgG anti-brucela o plasma humano normal, siendo máxima cuando la opsonización se produce con ambos ${ }^{(5)}$. Por otra parte la explosión oxidativa inducida por B. melitensis $16 \mathrm{M} \mathrm{y} \mathrm{B.} \mathrm{abortus} 544$ a bajas concentraciones es menor a la inducida por E. coli, siendo similar cuando se utilizan elevadas concentraciones bacterianas. Además la explosión oxidativa inducida por B. melitensis B115 (rugosa) es inferior a la 
inducida por B. melitensis $16 \mathrm{M} \mathrm{y} \mathrm{B.} \mathrm{abortus} 544$ tanto a medias como altas concentraciones $^{(5)}$.

\section{B.1.4. MECANISMOS O $\mathrm{O}_{2}$-INDEPENDIENTES}

Los mecanismos bactericidas oxígeno-independientes parecen contribuir escasamente a la destrucción de las brucelas por las células fagocíticas ${ }^{(158)}$. Las brucelas son resistentes a compuestos queladores de cationes divalentes (como EDTA) ${ }^{(172)}$, a sustancias policatiónicas (como la polimixina $\mathrm{B}^{(173)}$ ) y a las proteínas lisosomales catiónicas $^{(160)}$. A este respecto ni las cepas lisas ni rugosas son susceptibles a los extractos granulares de leucocitos polimorfonucleares ${ }^{(174)}$. Estas sustancias actúan por desplazamiento de los cationes divalentes $\left(\mathrm{Ca}^{++} \mathrm{y} \mathrm{Mg}^{++}\right)$que estabilizan la membrana externa mediante interacción con las cargas negativas del LPS de enterobacterias (KDO y grupos fosfato no sustituidos del núcleo y lípido A) ${ }^{(27)}$. En el caso de Brucella, su LPS presenta menor cantidad de KDO y bajo contenido en grupos fosfato ${ }^{(175)}$, de forma que no está estabilizado por cationes divalentes ${ }^{(172)}$, sino principalmente por interacciones hidrofóbicas entre los lípidos A y entre el lípido A y otros lípidos y proteínas ${ }^{(173)}$. Esto explica la ausencia de actividad de las proteínas catiónicas sobre Brucella ${ }^{(176-178)}$.

\section{B.2. DETERMINANTES DE PATOGENICIDAD (mecanismos de virulencia)}

En contraste a otros patógenos intracelulares, las brucelas no poseen plásmidos o bacteriófagos lisogénicos, los cuales podrían conferir propiedades de invasión o virulencia. Tampoco producen exotoxinas ni cápsulas antifagocíticas, ni se hallan formas de resistencia, ni tienen gruesas paredes celulares, ni poseen fimbrias ni muestran variación antigénica ${ }^{(158)}$.

\section{B.2.1. FACTORES METABÓLICOS}

\section{B.2.1.1. ENZIMAS Y OTROS PRODUCTOS GÉNICOS}

\section{Superóxido dismutasa (SOD)}

Pudiera ser una de las enzimas que intervienen en la patogenicidad de las brucelas. Protege a las células del efecto tóxico de los radicales superóxido $\left(\mathrm{O}_{2}{ }^{-}\right)$convirtiéndolos en $\mathrm{H}_{2} \mathrm{O}_{2}$ y oxígeno $\mathrm{O}_{2}$. En $B$. abortus se distinguen dos tipos de $\mathrm{SOD}^{(156)}$ : una $\mathrm{Cu} / \mathrm{Zn}$ 
SOD de localización periplásmica ${ }^{(179)}$ y una $\mathrm{Mn} \mathrm{SOD}^{(180)}$. Sin embargo como están presentes en similares proporciones en cepas de diferentes grados de virulencia, parecen no tener ningún papel como factor de virulencia. Esto fue confirmado por Latimer et al. ${ }^{(181)}$ que no encontraron diferencias relevantes comparando la virulencia en el ratón de B. abortus 2308 y una cepa mutante deficiente en $\mathrm{Cu} / \mathrm{Zn}$ SOD. Por el contrario Tatum et al. ${ }^{(182)}$ observaron un menor peso, número de bacterias y lesiones en el bazo de los ratones infectados con la cepa mutante deficiente que con la cepa originaria. Estas diferencias son más marcadas sobre los 10 a 26 días post-infección, lo cual favorece la hipótesis de que la $\mathrm{Cu} / \mathrm{Zn} \mathrm{SOD}$ podría jugar un papel en las primeras fases de la infección, pero podría no ser necesaria para la persistencia de B. abortus en el ratón. El papel de la Mn SOD en la patogénesis de Brucella no ha sido todavía bien estudiado $^{(156)}$.

Por otra parte y en contraste con algunos parásitos intracelulares como Legionella ${ }^{(183)}$ y Leishmania, la fosfomonoesterasa de B. abortus, con actividad fosfatasa ácida, no bloquea la producción del anión superóxido $\left(\mathrm{O}_{2}^{-}\right)^{(184)}$.

\section{Catalasa}

Catalíticamente convierte $\mathrm{H}_{2} \mathrm{O}_{2}$ en $\mathrm{H}_{2} \mathrm{O}$ y $\mathrm{O}_{2}$ y ha sido sugerida como mecanismo protector de Brucella de los intermediarios tóxicos de oxígeno liberados por los macrófagos tras la fagocitosis. Así la virulencia de B. abortus se correlacionó de manera directa con su actividad catalasa (cepas de alta virulencia mostraban alta actividad

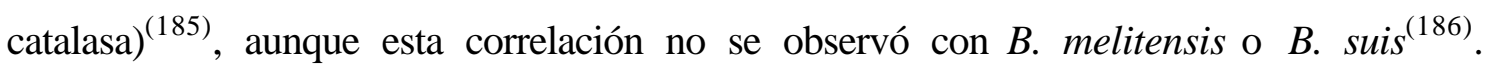
Además la localización periplásmica de la catalasa en $B$. abortus ${ }^{(187)}$ podría implicar que su papel es defender a la bacteria del $\mathrm{H}_{2} \mathrm{O}_{2}$ exógeno. Jiang et al. ${ }^{(188)}$ demostraron que la adición de catalasa exógena bloquea parcialmente las actividades antibrucela exhibidas por macrófagos aunque hay que tener en cuenta que la adición antes de la fagocitosis no imita las condiciones in vivo. Utilizando una cepa mutante catalasa negativa, sólo se observa un menor nímero de bacterias de la cepa mutante que de la cepa 2308 durante las 5 primeras horas de infección in vitro, pero posteriormente la cepa mutante se recupera más rápidamente e incluso alcanza mayor número tras $48 \mathrm{~h}$ de infección ${ }^{(156)}$. Además, no presentan diferencias en su capacidad para colonizar el bazo de ratones infectados. Tras la segunda semana de infección la cepa mutante muestra una significativa reducción en el número de bacterias esplénicas con respecto a la cepa 2308, aunque ambas cepas persisten al menos 18 semanas. Estos resultados sugieren 
que aunque la catalasa podría jugar un papel en la supervivencia de B. abortus dentro de los macrófagos activados, esto no es suficiente para producir un aclaramiento intracelular de las brucelas sin actividad catalásica.

\section{Proteína RecA}

La proteína RecA está implicada en la recombinación entre fragmentos homólogos de $\mathrm{ADN}$ y en la recombinación-reparación de $\mathrm{ADN}$ dañado. En E. coli, la proteína RecA es todavía más importante que la catalasa o la SOD para proteger la bacteria de las roturas en una hebra de $\mathrm{ADN}$ inducidas por $\mathrm{H}_{2} \mathrm{O}_{2}{ }^{(189)}$. Para determinar su papel en la virulencia, Tatum et al. ${ }^{(190)}$ construyeron un mutante recA de B. abortus y observaron un número menor de bacterias por bazo en los ratones infectados con la cepa mutante, que podría ser atribuido en parte a una incrementada sensibilidad a la mutagénesis oxidativa. Sin embargo la persistencia de ambas cepas en el ratón a los 100 días postinfección, indica que RecA no es crucial para la resistencia de B. abortus en el ratón.

\section{Operón purE}

Mutaciones en vías metabólicas esenciales generan cepas bacterianas atenuadas con reducida virulencia ${ }^{(22 ;}$ 24) . Drazek et al. ${ }^{(21)}$ produjeron una cepa mutante purE de B. melitensis $16 \mathrm{M}$ la cual requiere purinas para su crecimiento y observaron que tenía una capacidad disminuida de replicación en los macrófagos derivados de monocitos humanos. Esta menor replicación podría deberse a la incapacidad de estos mutantes para producir exceso de purinas, con el consecuente fallo en el bloqueo de la fusión fagosoma-lisosoma.

\section{B.2.1.2. PROTEÍNAS DE RESPUESTA AL ESTRÉS}

Los patógenos intracelulares facultativos, incluyendo $B$. abortus, generalmente expresan altos niveles de proteínas cuando son fagocitados por macrófagos ${ }^{(25)}$ y crecen en el ambiente intracelular. Así se ha pensado que estas proteínas de respuesta al estrés podrían jugar un papel importante en la adaptación fisiológica de la bacteria al ambiente hostil del fagosoma del huésped ${ }^{(28)}$, es decir actuar como factores de virulencia ${ }^{(191)}$.

Lin and Ficht ${ }^{(192)}$ estudiaron y compararon el perfil proteico de B. abortus durante dos situaciones de estrés como son el crecimiento intracelular en macrófagos y la exposición a condiciones ácidas, y observaron un incremento en la síntesis de proteínas de peso molecular 62, 60, 28, 24, y $17 \mathrm{kDa}$. Las proteínas de 17 y $28 \mathrm{kDa}$ son aparentemente inducidas de forma específica durante el crecimiento intracelular. La 
proteína de $62 \mathrm{kDa}$ fue identificada como una "heat shock protein" (Hsp62) y presenta homología con la proteína GroEL de E. coli que también es un miembro de la familia de Hsp (Hsp60) ${ }^{(193)}$. La proteína de $60 \mathrm{kDa}$, expresada durante el shock ácido, parece ser una variante de la Hsp62. Se ha propuesto a estas proteínas como responsables de la estimulación de una notable respuesta inmune del huésped durante el curso de la infección por Brucella ${ }^{(193)}$. La producción de la proteína de $24 \mathrm{kDa}$, inducida en las dos situaciones de estrés, se correlaciona con la supervivencia bacteriana bajo condiciones ácidas $(\mathrm{pH}<4)$.

La identificación de estos productos génicos y los mecanismos que controlan su expresión es un paso importante para entender la resistencia de Brucella a la destrucción intracelular dentro de los macrófagos.

\section{Proteína DnaK}

Es una proteína ("molecular chaperon") producida por B. suis en condiciones adversas como choque de calor y $\mathrm{pH}$ bajo, o durante la multiplicación intracelular y que es requerida para el crecimiento a $37^{\circ} \mathrm{C}^{(194)}$. En E. coli la delección del gen dnaK incrementa su grado de muerte intracelular y disminuye su resistencia a $\mathrm{H}_{2} \mathrm{O}_{2}$, mientras que si este mutante se complementa con el operón dnaK/dnaJ de B. ovis, el E. coli resultante tolera el $\mathrm{pH}$ bajo y el $\mathrm{H}_{2} \mathrm{O}_{2}$ mejor que la cepa salvaje ${ }^{(195)}$. Así mismo se observó que una cepa mutante, defectiva en dnaK, de B. suis veía afectada su viabilidad a bajo $\mathrm{pH}$ y no podía multiplicarse en los macrófagos $\left(\mathrm{a} 30^{\circ} \mathrm{C}\right)$, por lo tanto la proteína DnaK contribuye, de manera independiente a la temperatura, a la multiplicación intracelular de B. suis $^{(194)}$.

\section{Proteína HtrA (High-temperature-requirement A protein)}

La proteasa de respuesta al estrés HtrA, está implicada en la degradación de las proteínas dañadas por mecanismos oxidativos, entre otros, y por tanto podría contribuir significativamente a la resistencia a las vías bactericidas oxidativas de los fagocitos. Elzer et al. ${ }^{(196)}$ obtuvieron un mutante de B. abortus por delección del gen htrA, que mostró ser más sensible a la muerte oxidativa in vitro y ser menos capaz de sobrevivir en cultivos de macrófagos y neutrófilos murinos. Además esta mutante presentó un menor nivel de colonización esplénica durante los estadíos tempranos de la infección en el modelo de ratón $\mathrm{BALB} / \mathrm{c}^{(197)}$, aunque Tatum et al. ${ }^{(198)}$ demostraron que tras la inicial reducción, los niveles de infección esplénica se recuperan y vuelven a ser similares a los 
mostrados por la cepa parental. Por otra parte, aunque puede cambiar la capacidad de colonización, la virulencia de la cepa mutante de $B$. abortus en las cabras preñadas no pareció estar reducida ${ }^{(199)}$. Similares resultados se obtuvieron con una cepa mutante para B. melitensis $16 \mathrm{M}$ en el modelo murino ${ }^{(200)}$. La infección experimental del ratón con esta mutante mostró una atenuación significativa en la semana siguiente a la infección, produciéndose una recuperación de la multiplicación bacteriana en bazo e hígado en los días posteriores de forma que no se observaron diferencias en los recuentos entre B. melitensis $16 \mathrm{M}$ y su mutante. Las bases para esta atenuación transitoria de los mutantes htrA en el modelo murino es actualmente desconocida.

\section{B.2.1.3. ERITRITOL}

El eritritol es un poliol de 4 carbonos que ha sido relacionado con la virulencia basándose en el hecho de que es una eficaz fuente de carbohidratos para B. abortus, B. melitensis y B. suis ${ }^{(201)}$, mientras que la cepa avirulenta B. abortus $\mathrm{B} 19$ ha perdido su capacidad para utilizarlo y es inhibida por su presencia en el medio ${ }^{(202)}$. Su presencia en la placenta de vacas, ovejas, cabras y cerdos podría correlacionarse con el organotropismo de las brucelas hacia estos tejidos, estando en bajas concentraciones en la placenta de humanos (donde no se localiza) y en la placenta de roedores ${ }^{(202 ; 203)}$. Sin embargo existen argumentos en contra de su papel en la virulencia como son la proliferación preferencial de las brucelas que no oxidan eritritol (B. ovis), o que son inhibidas por él (B. abortus B19), en la placenta de rumiantes. Por otra parte aunque se encuentran a concentraciones bajas en las placentas de los roedores, B. abortus también se localiza preferencialmente en estos tejidos ${ }^{(202)}$. Además el eritritol no está presente en los macrófagos, lugar donde también se localizan y multiplican las brucelas. La cepa B19 es defectiva en una de las enzimas de la vía catabólica del eritritol (D-erythrulose1-P-dehidrogenasa) ${ }^{(204)}$ pudiendo ser la base para su sensibilidad al eritritol. Recientemente Sangari et al. ${ }^{(205)}$ demuestran que el defecto en el metabolismo del eritritol de la cepa B19 no está relacionado con su virulencia atenuada.

\section{B.2.1.4. OTROS DETERMINANTES DE PATOGENICIDAD}

\section{Sideróforos}

Se conoce poco sobre el papel de las proteínas secuestrantes de hierro y otros sideróforos en la patogénesis de la brucelosis. En general la baja disponibilidad de hierro in vivo restringe el crecimiento microbiano ${ }^{(206)}$. Sin embargo altas 
concentraciones de hierro incrementan la actividad bactericida de los macrófagos frente a las brucelas intracelulares ${ }^{(207)}$, probablemente como resultado de la capacidad del hierro para catalizar la reacción de Haber-Weiss en la que se generan radicales hidroxilo a partir de peróxido de hidrógeno y de superóxido.

La adición a los cultivos de macrófagos activados con IFN $\gamma$ o suplementados con hierro, del ácido 2,3-dihidroxibenzoico, un sideróforo producido por B. abortus $^{(208)}$, previene la muerte intracelular de las brucelas durante las primeras 12 h post-infección e incrementa el número de brucelas intracelulares recuperadas tras $48 \mathrm{~h}^{(209)}$. Sin embargo Denoel et al. ${ }^{(210)}$ demuestran que la bacterioferritina, otro sideróforo, no es esencial para la supervivencia intracelular de $B$. melitensis en macrófagos derivados de monocitos humanos.

\section{Factor inhibidor de TNF- $\alpha$}

Caron et al. ${ }^{(211 ; 212)}$ demostraron que las brucelas liberan algunos factores de naturaleza proteica que específicamente inhiben la expresión de TNF- $\alpha$ en macrófagos humanos activados, pero no en los murinos. De este modo estos factores podrían contribuir a la evasión por parte de la brucela de las defensas antimicrobianas en macrófagos humanos, donde a diferencia del ratón pueden persistir y multiplicarse. Esto explicaría en cierta medida la tendencia hacia la cronificación de la infección brucelar en el hombre.

\section{B.2.2. FACTORES DE VIRULENCIA ESTRUCTURALES}

El papel de los componentes de la membrana externa en la virulencia de los microorganismos intracelulares no está bien establecido. Sólo dos componentes de la membrana externa han sido implicados como potenciales factores de virulencia: las proteínas de la membrana externa y el lipopolisacárido.

\section{B.2.2.1. MEMBRANA EXTERNA}

Como en otras bacterias Gram negativas, Brucella presenta una envoltura celular formada por una membrana externa superpuesta a una delgada capa de peptidoglicano y separada de la membrana citoplasmática por un espacio periplásmico. La membrana externa es asimétrica y está formada por fosfolípidos, localizados principalmente en la cara interna, y por LPS y proteínas localizados en la cara externa ${ }^{(27)}$. 
Aunque morfológicamente es similar a otras bacterias Gram negativas, la composición química y las propiedades físicas de la envoltura diferencian al género Brucella de otras bacterias Gram negativas.

Las principales diferencias se encuentran en la composición lipídica de la envoltura externa $^{(27)}$ hecho que las acerca a la subdivisión alpha-2 de las Proteobacteria (Agrobacterium, Rhizobium, Ochrobactrum, Rochalimae ${ }^{(158)}$. El principal fosfolípido de la membrana externa de Brucella es la fosfatidilcolina, a diferencia de las enterobacterias que es la fosfatidiletanolamina, la cual parece implicada en la resistencia frente a la polimixina $\mathrm{B}^{(173)}$. También presenta OCL el cual está probablemente implicado en la adherencia ${ }^{(158)}$ y además posiblemente actúe como agente estabilizante del LPS en lugar de los cationes divalentes ${ }^{(178)}$. Por otra parte el LPS de Brucella presenta un contenido pequeño de KDO y una pérdida de grupos fosfato, lo que determina una fuerte asociación con las proteínas ${ }^{(213)}$. Además presenta ésteres tipo cera, una lipoproteína expuesta en la superficie celular y ácidos grasos de cadena larga que son infrecuentes en otras bacterias gram negativas.

Todas estas características son factores que contribuyen a la alta hidrofobicidad y al mantenimiento de asociaciones cerradas entre las macromoléculas de la membrana externa de las brucelas, que podría tener implicaciones en la resistencia y en la adaptación a la vida intracelular.

\section{B.2.2.2. PROTEÍNAS DE LA MEMBRANA EXTERNA}

Se han descrito diferentes grupos de proteínas expuestas en la membrana externa (OMP=outer membrane proteins) de Brucella spp. $^{(214)}$. Las proteínas principales incluyen: a) una lipoproteína covalentemente unida al peptidoglicano, muy similar a la de E. coli; b) proteínas del grupo $2(35-40 \mathrm{kDa})$ que tienen actividad de porina actuando como canales al interior de la célula ${ }^{(213)}$; c) proteínas del grupo $3(25-30 \mathrm{kDa})$, que en base a su composición de $\operatorname{aminoácidos~}^{(215)}$, su fuerte unión a peptidoglicano ${ }^{(214)}$ y su modificabilidad por calor $^{(216)}$ podrían ser el equivalente en Brucella de la OmpA de E. coli. Sin embargo, estudios recientes han concluido que estas proteínas no son de la familia de $\mathrm{OmpA}^{(217)}$ aunque podrían jugar un papel similar. Las proteínas secundarias son: grupo 1 de proteínas (88-94 kDa), y también otras proteínas identificadas (10-34 $\mathrm{kDa})^{(218)}$. 
La OMP de $38 \mathrm{kD}$ puede ser un factor de virulencia de brucela pues no posee actividad protectora $^{(219)}$ y la presencia del gen que la codifica en cepas de E. coli las permite sobrevivir más efectivamente en la línea celular de macrófagos U937 ${ }^{(220)}$. Halling et al. ${ }^{(221)}$ demostraron que la proteína periplásmica BCSP 31, una proteína inmunógena de $31 \mathrm{kDa}$ muy conservada en las distintas especies de Brucella $^{(222)}$, no estaba implicada en la invasión, crecimiento o replicación de $B$. abortus en la línea celular de macrófagos J774.

Ficht et al. clonaron una región que codifica una OMP de B. abortus de $36 \mathrm{kDa}$ (locus omp2) que además contiene dos genes estrechamente relacionados, omp2a y omp2b, presentes en los genomas de todas las especies de Brucella y cuyo polimorfismo puede ser usado en la clasificación de las mismas ${ }^{(223)}$. Aunque ambos genes contienen marcos de lectura abiertos que codifican proteínas con un $96 \%$ de homología, sólo ha sido demostrada la expresión de omp2b en B. abortus en el laboratorio y corresponde a la porina caracterizada de Brucella de $36 \mathrm{kDa}$. Por otra parte aunque silente en condiciones normales, la conservación del gen omp2a sugiere la posibilidad de que se exprese bajo condiciones especificas. Estos genes, omp2a y omp2b, han sido expresados en E. coli, y sus productos se localizan en la membrana externa de la célula, demostrando que el producto del gen omp2a tiene una actividad poro-formadora ${ }^{(224)}$. Por todo ello se ha sugerido que Brucella podría adaptarse a los cambios en las condiciones ambientales, tales como el ambiente intracelular, modulando la expresión de genes de porinas y aumentando la producción de poros, lo que podría estar relacionado con su supervivencia intracelular.

Un hipotético papel de las OMP brucelares en la virulencia puede ser inferido de su capacidad para producir una respuesta inmune protectora. Los animales infectados desarrollan anticuerpos frente a varias $\mathrm{OMP}^{(225)}$. Estos anticuerpos también se han encontrado en humanos ${ }^{(226)}$, si bien las personas infectadas tienden a desarrollar una menor respuesta frente a los antígenos proteicos que frente al LPS ${ }^{(206)}$. El papel de los anticuerpos antiOMP no está claro, aunque parecen jugar un menor papel en la protección que los anticuerpos anti SLPS. Así los anticuerpos monoclonales para OMP protegen menos a los ratones de la infección con $B$. abortus que los anticuerpos monoclonales frente al S-LPS ${ }^{(227)}$. De la misma forma los anticuerpos inducidos en el ganado frente a las proteínas de la cepa B19 de B. abortus no son capaces de conferir protección $^{(228)}$. 


\section{B.2.2.3. LIPOPOLISACÁRIDO (LPS)}

Como en otras bacterias Gram negativas, el LPS es la molécula lipídica más abundante en la envoltura externa de las brucelas. En las cepas en fase lisa (S), el S-LPS está formado por el lípido $\mathrm{A}$, el núcleo de carácter oligosacarídico y la cadena polisacarídica O específica. La estructura del LPS de las cepas rugosas (R-LPS) es básicamente similar excepto que la cadena $\mathrm{O}$ esta ausente o reducida a unos pocos residuos de monosacáridos ${ }^{(206)}$.

\section{Lípido A}

$\mathrm{Su}$ estructura es distinta al lípido A de las enterobacterias. Contiene como azúcar central la 2,3-diamino-2,3-dideoxi-D-Glucosa sustituida por ácidos grasos saturados unidos por enlaces amida y éster. La D-glucosamina también está presente pero no se sabe con certeza si es un componente central del lípido A. Los ácidos grasos en unión amida están presentes en su mayoría como 3 hidroxiácidos sustituidos (residuos 3-aciloxiacil) y son principalmente: 3-O(16:0)14:0, 3-O(16:0)12:0, 3-O(18:0)14:0, 3-O(16:0)13:0, 3-OH-16:0 y 3-OH-14:0. Los ácidos grasos en unión éster son el 16:O y 18:O, también presentes en forma $3 \mathrm{OH}$. El lípido A parece contener muy pequeñas cantidades de fosfato y está unido al KDO del núcleo probablemente en el carbono $6^{627}$ $159 ; 175)$.

\section{Núcleo del LPS}

$\mathrm{Su}$ estructura no ha sido dilucidada en ninguna especie de Brucella. Es una corta cadena oligosacarídica de glucosa, manosa, 2-amino-2,6-dideoxi-D-glucosa (quinovosamina) y $\mathrm{KDO}$ (sin fosfato) que une la cadena $\mathrm{O}$ al lípido $\mathrm{A}$. Las cepas rugosas no contienen quinovosamina. Se diferencia del núcleo del LPS de las enterobacterias en el menor contenido de KDO y en la ausencia de fosfato y heptosas $^{(159 ; 175)}$.

\section{Cadena O}

Consiste en un homopolímero de 4,6-dideoxi-4-formamido-D-manosa (D-Rha4NFo) de longitud variable (30 a 100 residuos). Mediante anticuerpos monoclonales se han descrito 4 epítopos específicos en la cadena O: A, M, C y C/Y ${ }^{(229)}$. El epítopo A está formado por 4 o 5 residuos de D-Rha4NFo unidos por enlaces $\alpha-1,2^{(230)}$. Se encuentra de forma dominante en B. abortus biov. 1, 2, 3 y 6, B. melitensis biov. 2 , B. suis biov. $1,2,3, \mathrm{y} B$. neotomae ${ }^{(159)}$. El epítopo M está formado por 5 residuos D-Rha4Nfo, cuatro 
unidos por enlaces $\alpha-1,2$ y el quinto residuo unido por enlace $\alpha-1,3^{(230)}$. Este epítopo $\mathrm{M}$ se encuentra de forma dominante en B. abortus biov. 4, 5 y 9, B. melitensis biov.1 y B. suis biov. 5 (B. melitensis biov. 3 y B. suis biov. 4 son $\mathrm{A}+, \mathrm{M}+)^{(159)}$. El epítopo $\mathrm{C}$ es estrictamente específico para las cepas lisas de Brucella spp., tanto A como M dominantes y no está todavía bien definido. El epítopo $\mathrm{C} / \mathrm{Y}$ común a Brucella spp. y Y. enterocolitica 0:9 parece ser una secuencia de 2 a 4 unidades de residuos D-Rha4Nfo unidos por enlaces $\alpha-1,2^{(229)}$. A pesar del conocimiento que se tiene sobre el polisacárido $\mathrm{O}$, la diversidad de los epítopos localizados en la cadena $\mathrm{O}$ es más compleja que la previamente descrita, y los ensayos de unión con anticuerpos monoclonales sugieren que los diferentes epítopos probablemente se solapen mutuamente ${ }^{(229)}$.

Existen otros polisacáridos ${ }^{(27 ;}{ }^{231)}$ de Brucella, originariamente definidos por su reactividad serológica cruzada $^{(232)}$ con la cadena $\mathrm{O}$ y que han sido objeto de controversia. El hapteno nativo $(\mathrm{HN})$, presente en distintos biotipos de B. melitensis y B. abortus $^{(233)}$ es un homopolímero de $\mathrm{N}$-formil perosamina ${ }^{(234)}$ y por tanto con estructura muy similar a la cadena $\mathrm{O}$, pero que constituye una estructura independiente en la membrana externa. Es probable que se encuentre interaccionando con la cadena $\mathrm{O}$ del LPS ${ }^{(235)}$, contribuyendo a su estabilización ${ }^{(178)}$, estando unido a la membrana externa por interacciones polisacárido-polisacárido y también existe evidencia de una unión con lípidos. El polisacárido $\mathrm{B}$, término inicialmente utilizado para un componente serológicamente activo obtenido de B. melitensis $115^{(233)}$ fue considerado por Bundle et al. ${ }^{(236)}$ como un glucano no reductor, circular, con 17-24 unidades de 3-Dglucopiranósido unidas por enlaces $\beta-1,2$, obtenido de extractos de B. melitensis $16 \mathrm{M}$, a pesar de que es serológicamente inactivo, lo cual difiere de la inicial definición por inmunoprecipitación del polisacárido $\mathrm{B}$; estos autores justifican su reactividad serólogica por una fuerte unión no covalente con la cadena $\mathrm{O}^{(237)}$.

\section{Otros lipopolisacáridos relacionados estructuralmente con el LPS de Brucella}

Existen reacciones serológicas cruzadas entre B. abortus y B. melitensis con otras bacterias gram negativas y en la mayoría de los casos es el LPS el factor responsable de las mismas ${ }^{(236)}$. Por otra parte el LPS de las bacterias gram negativas es el responsable de múltiples acciones biológicas de gran importancia en la patogenia de la infecciones producidas por estas bacterias. Esto hace que sea de gran interés el conocimiento 
estructural de estos LPSs, sus coincidencias y discrepancias estructurales y la actividad biológica por ellos desarrollada. Describiremos más detenidamente los utilizados en esta tesis por su relación estructural con el LPS de Brucella.

\section{LPS de Escherichia hermannii}

Esta bacteria ha sido descrita como un biogrupo atípico de E. coli ${ }^{(238)}$. Algunas cepas de esta bacteria presentan reacción serológica cruzada con E. coli $\mathrm{O} 157: \mathrm{H} 7$, B. abortus y B. melitensis y se ha visto que su LPS consta de una cadena $\mathrm{O}$ compuesta por un polímero lineal de residuos de 4-acetamido-4,6-dideoxi-D-manopiranosa, con dos estructuras diferentes. Cada una de estas estructuras tiene una unidad repetitiva pentasacarídica, una compuesta de tres enlaces $\alpha-1,2$ y dos $\alpha-1,3$ y la otra de dos enlaces $\alpha-1,2$ y tres $\alpha-1,3$ entre los residuos. Esta estructura similar a la presente en el polisacárido $\mathrm{O}$ de Brucella determinaría las reacciones serológicas cruzadas entre ambas especies bacterianas. El oligosacárido del núcleo está compuesto de D-glucosa, 2-acetamido-2-deoxi-D-glucosa, y L-glicero-D-manno-heptosa (relación molar 1:1:1). El lípido A muestra 2-amino-2-deoxi-D-glucosa y los ácidos laúrico, mirístico, palmítico y $\beta$-hidroximirístico ${ }^{(238 ; 239)}$.

\section{LPS de Yersinia enterocolitica 0:9}

La similitud entre el LPS de $Y$. enterocolitica y el LPS de Brucella viene determinada por la cadena O de su LPS ya que está formada por unidades de 4,6-dideoxi-4-formamido- $\alpha$-D-manopiranosil en unión $\alpha-1,2$. Por tanto las reacciones cruzadas con Brucella spp. tienen lugar por ser esta estructura idéntica. Sin embargo el núcleo y el lípido A difieren en $Y$. enterocolitica. El oligosacárido del núcleo está compuesto de D-galactosa, D-glucosa, L y D -glicero-D-manno-heptosas, KDO y 2-amino-2-deoxi-D-galactosa. El lípido A contiene 2-amino-2-deoxi-D-glucosa y los ácidos grasos: dodecanoico, tetradecanoico, hexadecanoico y 3-hidroxitetradecanoico $^{(240)}$.

\section{LPS de Pseudomonas maltophilia 555 [Stenotrophomonas(Xanthomonas)maltophilia]}

$\mathrm{Su}$ cadena $\mathrm{O}$ polisacarídica esta compuesta de una unidad repetitiva pentasacarídica que contiene: D-ramnosa (D-Rha, 1 parte), 3-acetamido-3,6-dideoxi-D-galactosa (D-Fuc3Nac, una parte) y 4acetamido-4,6-dideoxi-D-manosa (D-Rha4NAc, tres partes) teniendo la siguiente estructura: 


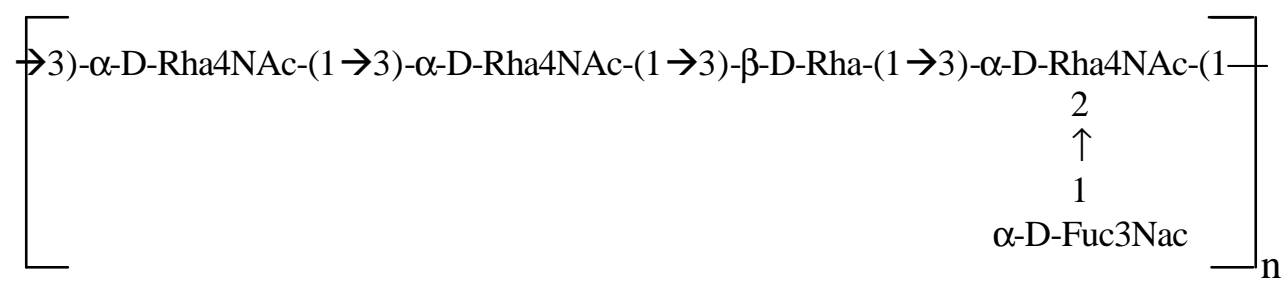

Las reacciones serológicas cruzadas entre P. maltophilia 555 y Brucella spp. pueden estar relacionadas con la presencia de $\mathrm{N}$-acil derivados de residuos 4-amino-4,6dideoxi-D-manopiranosil presentes en las cadenas $\mathrm{O}$ de sus respectivos LPS.

El oligosacárido del núcleo está compuesto por Dmanosa, 3-acetamido-3,6-dideoxiD-galactosa, D-glucosa, KDO y ácido hexurónico. El lípido A contiene 2-amino-2deoxi-D-glucosa y ácidos grasos: 2-hidroxi-9-metildecanoico, 3-hidroxi-9metildodecanoico, 3-hidroxidodecanoico, 3-hidroxi-11-dodecanoico, 13metiltetradecanoico, 12-metiltetradecanoico, hexadecanoico $\quad$ y $15-$ metilhexadecanoico $^{(241)}$.

\section{S-LPS de Ochrobactrum anthropi LMG 3331}

$\mathrm{Su}$ polisacárido $\mathrm{O}$ consiste en una cadena lineal, formada por la repetición de una unidad disacarídica constituida por $\mathrm{N}$-acetilglucosamina y ramnosa en forma piranósido con la siguiente estructura ${ }^{(242)}$ :

$$
\rightarrow 3)-\alpha-D-G l c ~ p \text { NAc- }(1 \rightarrow 2)-\alpha-L-R h a p-(1 \rightarrow
$$

Esta estructura es diferente al polisacárido $\mathrm{O}$ de Brucella lo que explica la falta de reactividad cruzada entre el suero de animales infectados con Brucella y el S-LPS de $O$. anthropi ${ }^{(243)}$. Sin embargo esta reactividad sí se ha observado entre el suero de animales infectados con Brucella spp. y el RLPS y la fracción rica en lípido A de $O$. anthropi, lo que sugiere que las reacciones cruzadas tienen lugar a nivel del núcleo o del lípido A. Su oligosacárido del núcleo, contiene ácido galacturónico, no presente en el LPS de Brucella, pero sin embargo sí contiene KDO, glucosa y glucosamina que también están presentes en el núcleo de Brucella y esto podría explicar la reactividad observada. Pero debemos también considerar que la reactividad mostrada por el lípido A indica que los determinantes antigénicos del mismo contribuyen significativamente a dicha reactividad $^{(243)}$, y así el lípido A de la cepa rugosa de O. anthropi LMG 3301 presenta en su estructura central un disacárido de 2,3-diamino-2,3-dideoxi-Dglucosa $^{(244)}$, que también es el azúcar central del lípido A de las brucelas. 
Otros LPS: que presentan reacciones cruzadas con el LPS de Brucella (aunque no ensayados en esta tesis) son los de: Escherichia coli $\mathrm{O} 157^{(236)}$, E. coli $\mathrm{O} 116^{(245)}$, Salmonella landau, Salmonella urbana y Salmonella godesberg (pertenecientes al grupo N de Kauffman-White O:30) ${ }^{(246)}$, Vibrio cholerae [O1 (formas Ogawa e Inaba), O140 (Hakata)] y Vibrio bio-serogrupo 1875 (cepas original y variante) ${ }^{(247)}$ y Francisella tularensis ${ }^{(245)}$.

\section{LPS como factor de virulencia}

Dado que el LPS de la membrana externa de las bacterias Gram negativas, y en especial de las enterobacterias, contribuye a la virulencia de éstas y es responsable de numerosas acciones biológicas, se pensó el LPS del Brucella mediaría en sus mecanismos patogénicos.

La virulencia de B. abortus, B. melitensis y B. suis está asociada al morfotipo liso (S) de colonia ${ }^{(248)}$, el cual contiene el LPS entero (S-LPS), de tal forma que las cepas lisas presentan una supervivencia intracelular incrementada con respecto a las cepas mutantes rugosas que son avirulentas y contienen un LPS incompleto (R-LPS) ${ }^{(163)}$. Por ello el SLPS ha sido propuesto como factor de virulencia. Así Soto et al. ${ }^{(249)}$ demostraron que el S-LPS de B. abortus o $B$. melitensis aumentaba la supervivencia intracelular en neutrófilos bovinos de la cepa rugosa 1119 de B. abortus. Existen algunos puntos contra esta hipótesis que considera al S-LPS como factor de virulencia, como son el hecho de que tanto las cepas lisas como las rugosas presentan un contenido de LPS en su superficie y una composición del lípido A, responsable de la actividad biológica, muy $\operatorname{similar}^{(250)}$. Otro punto que no apoyaría esta hipótesis es el hecho de que algunas especies de Brucella (B. canis y B. ovis) plenamente virulentas, son de forma natural rugosas, si bien presentan una capacidad limitada para establecer la infección en otras especies diferentes a sus huéspedes naturales ${ }^{(159)}$. Del mismo modo se opondría a esta hipótesis el hecho de que la especie lisa $B$. neotomae no es patogénica.

La actividad biológica del S-LPS de Brucella presenta diferencias cualitativas y cuantitativas importantes con los LPSs de las enterobacterias. Así el LPS de Brucella no es pirogénico para el conejo, no es letal para embriones de conejo o de pollo ni incrementa la susceptibilidad a histamina ${ }^{(27)}$. Sin embargo presenta otras acciones ${ }^{(251)}$ aunque siempre con menor actividad que el LPS de las enterobacterias: toxicidad para ratones y macrófagos; inducción de leucopenia y leucocitosis; hipoferremia y aborto en ratón; activación del complemento y mitogenicidad para linfocitos $\mathrm{B}$ de ratón. Estas 
actividades son producidas tanto por los S y RLPS como por el lípido A. Además el LPS induce la producción de TNF y de IFN. Otros efectos, relacionados con las actividades de las células fagocíticas son la inducción de la explosión oxidativa y la desgranulación. El LPS de Brucella es mucho menos activo que el de Salmonella en la inducción de la explosión oxidativa. Así son necesarias 100 veces más de LPS de B. abortus y 1000 veces más de lípido A para inducir el mismo nivel de reducción del colorante nitroazul de tetrazolium y de producción de lisozima por neutrófilos humanos que el inducido por el LPS de Salmonella y su lípido $\mathrm{A}^{(252)}$. Además la inducción de la explosión oxidativa es dosis dependiente, si bien a concentraciones inferiores a 100 $\mu \mathrm{g} / \mathrm{ml}$, la inducida por el LPS de E. coli es muy superior a la inducida por los S-LPSs de B. melitensis $16 \mathrm{M}$ y B. abortus 544, siendo el lípido A de E. coli también más potente inductor que los respectivos lípidos A de Brucella $^{(5)}$. Sin embargo la activación policlonal de linfocitos B murinos es similar al LPS de enterobacterias. Por otra parte el LPS de Brucella es capaz de estimular la producción de IL-1 y TNF en ratones $\mathrm{C} 3 \mathrm{H} / \mathrm{HeJ}$, los cuales se caracterizan por ser no respondedores a la endotoxina de las enterobacterias $^{(253)}$. Estas distintas actividades biológicas inducidas por el LPS de Brucella están relacionadas con su estructura única ${ }^{(156)}$. Su baja actividad biológica argumentaría en contra de su papel como mecanismo de virulencia ${ }^{(158)}$, sin embargo, algunos autores proponen que precisamente este hecho podría ser una de los factores contribuyentes a la supervivencia en células fagocíticas ${ }^{(252)}$.

Aunque el LPS parece estar implicado en la supervivencia intracelular no es el único factor determinante, como se ha demostrado al comparar cepas lisas virulentas con mutantes rugosos genéticamente inducidos ${ }^{(254)}$. Estos casos parecen demostrar que el mantenimiento de la integridad de la membrana es un factor tanto o más importante que la mera presencia o ausencia de S-LPS ${ }^{(158)}$.

La respuesta humoral está dirigida principalmente contra el $\operatorname{LPS}^{(178 ; 255)}$. La cadena O del S-LPS parece ser el antígeno inmunodominante. La mayor proporción de la respuesta protectora de anticuerpos de animales o humanos, infectados o inmunizados con especies de Brucella lisas, está dirigido contra este antígeno ${ }^{(256 ; 257)}$. El suero inmune frente a S-LPS ha demostrado ser protector en el ratón ${ }^{(258)}$ y los anticuerpos monoclonales y policlonales frente a los epítopos $\mathrm{A}$ y $\mathrm{M}^{(259)}$ de la cadena O del S-LPS de Brucella tienen la capacidad de proteger al ratón contra la infección con Brucella. 
Esto indica que los epítopos A y M pueden tener un papel como determinantes de virulencia $^{(178)}$.

El LPS de Brucella ha sido propuesto como factor de virulencia por sí mismo. Actúa como una barrera protectora evitando la acción digestiva de los fagocitos. Es el principal sistema de resistencia a las proteínas lisosomales catiónicas, así como a péptidos catiónicos bactericidas como la polimixina B y la lactoferricina $\mathrm{B}$ y a los quelantes de cationes divalentes tal y como mencionamos anteriormente ${ }^{(178)}$. 


\section{OBJETIVOS}


Como objetivos de este trabajo de tesis doctoral nos propusimos:

1.- Determinar si los lipopolisacáridos de Brucella abortus 544 y Brucella melitensis $16 \mathrm{M}$ son capaces de inducir la producción de óxido nítrico en los macrófagos peritoneales de rata, y compararla con la capacidad inductora de NO del LPS de Escherichia coli.

2.- Determinar la capacidad de los S-LPSs de B. abortus y B. melitensis para inducir la producción de NO a través de la vía de la L-arginina, determinando si inducen la transcripción y síntesis de la isoforma inducible de la óxido nítrico sintasa (iNOS).

3.- Determinar si los lípidos A de Brucella abortus 544 y Brucella melitensis 16M son capaces de inducir la producción de óxido nítrico y la transcripción de la iNOS en los macrófagos peritoneales de rata, y ver si existen diferencias con la inducción producida por el lípido A de Escherichia coli.

4.- Determinar la capacidad de los lipopolisacáridos de Escherichia hermannii, Yersinia enterocolitica 0:9, Pseudomonas maltophilia 555 y Ochrobactrum antrhopi LMG 3331, relacionados serológicamente con Brucella, de inducir la producción de NO y la transcripción de la iNOS en los macrófagos peritoneales de rata. 


\section{MATERIAL Y MÉTODOS}




\subsection{REACTIVOS}

\section{Asta Medica (España)}

- Betadine solución dérmica (povidona yodada)

Ambion Inc. (Austin, EE.UU.)

- ARNasa

\section{Antibióticos Farma SA (España)}

- Unicilina (penicilina G sódica) 1 millón U

\section{Amersham International (Buckinghamshire, Reino Unido)}

- Anticuerpo de burro anti-IgG de conejo conjugado con peroxidasa de rábano

- Películas de autorradiografía Hyperfilm MP e Hyperfilm ECL

- Sistema de aumento de quimioluminiscencia (ECL)

- 2-desoxirribocitidintrifosfato marcado con ${ }^{32} \mathrm{P}\left(\left[\alpha_{-}{ }^{32} \mathrm{P}\right] \mathrm{dCTP}\right)$

Bio101, Inc. Corporation (La Jolla, CA, EE.UU.)

- Kit Geneclean II de purificación de ADN

Bio Rad Laboratories (Hercules, CA, EE. UU.)

- Solución de acrilamida-bis-acrilamida al 30\%;37,5:1 (2,6\% C)

- Marcadores proteicos de alto y bajo peso molecular

- Colorante para ensayo de proteínas (Coomassie brilliant blue G-250)

Bio-Whittaker (Walkersville, MD, EE.UU.)

-.Dulbecco's Modified Eagles Medium (DMEM) sin L-Glutamina ni rojo de fenol

\section{Boehringer Mannheim (Mannheim, Alemania)}

-Ácido 4-morfolinopropanosulfónico (MOPS) 
Calbiochem (La Jolla, California, EE.UU.)

- Anticuerpo de conejo contra la iNOS de rata

\section{Costar Corporation (Cambridge, MA, EE.UU.)}

- Placas de cultivo de 24 pocillos y placas de $35 \mathrm{~mm}$

- Pipetas estériles

- Raspadores de placas de cultivo

\section{Fluka Chemie (Buckinghamshire, Reino Unido)}

- Ácido bórico

- Acetato potásico

- Alcohol isoamílico (3-metil-1-butanol)

- Azul de toluidina

- Borato sódico

- Dodecil sulfato sódico (SDS)

- Fenol

- Formaldehido

- Glicerol

- Ioduro sódico

- Isopropanol

- Sephadex G 200 y G 10

- Tiocianato de guanidinio

- Trietilamina

\section{ICN-Flow (Irvine, Reino Unido)}

- Ácido N-(2-hidroxietil)piperacina-N'-2-etanosulfónico (HEPES)

\section{Merck (Darmstadt, Alemania)}

- Ácido fórmico

- Acetato amónico

- $\beta$-mercaptoetanol

- Citrato trisódico dihidratado

- Cloroformo 
- Cloruro de litio

- Cloruro de magnesio hexahidratado

- Cloruro sódico

- Cloruro potásico

- Dimetilsulfóxido (DMSO)

- Dihidrógeno fosfato de potasio

- Glicina

- Hidrógenofosfato de di-sodio hidratado

- TRIS-(hidroximetil)-aminoetano

- Triton X-100

\section{Millipore S.A. (Molsheim,Francia)}

- Filtro estéril de $0.22 \mu \mathrm{m}$

\section{Normon Laboratorios S.A.(Madrid)}

- Ampicilina

\section{Nunc (Naperville, IL, EE.UU.)}

- Tubos Falcon $50 \mathrm{ml}$

\section{Oxoid}

- Caldo Brucella

\section{Panreac Química S:A: (Barcelona)}

- Ácido acético

- Ácido clorhídrico

- Etanol

- Éter dietílico

- Metanol

- Hidróxido sódico 


\section{Pharmacia Biotech (Uppsala, Suecia)}

- 2-deoxinucleótidos-5' -trifosfato (dNTP)

- Cebadores hexaméricos al azar

\section{Promega (Madison, WI, EE.UU.)}

- Enzimas de restricción: BamHI

- Fragmento Klenow

- Buffer E (10X)

- Marcadores para electroforesis de ADN: ADN del fago lambda digerido con Hind III

\section{Pronadisa (Alcobendas,Madrid, España)}

- Agarosa para electroforesis de ácidos nucleicos

- Extracto de levadura

- Triptona

\section{Schleicher \& Schvell (Dassel, Alemania)}

- Membrana para "Northern blotting" de "Nytran": NY13N de 0,45 $\mu \mathrm{m}$

- Membrana para "Western blotting" de nitrocelulosa: Protran de 0,45 $\mu \mathrm{m}$

\section{Sigma (St. Louis, MO, EE:UU:)}

- Acetato sódico

- Ácido etilendiamino tetraacético (EDTA)

- Ácido etilenglicol-bis-( $\beta$-aminoetileter)-N,N,N,N-tetraacético (EGTA)

- Ácido sulfanílico

- Albúmina de suero bovino (BSA)

- Aprotinina

- Azul de bromofenol

- Bromuro de etidio (BrEt)

- Dietilpirocarbamato (DEPC)

- Ditiotreitol (DTT)

- Fenil metil sulfonil fluoruro(PMSF)

- Fluoruro sódico 
- Formamida

- Gentamicina sulfato

- L-arginina

- L-glutamina

- Leupeptina

- Lipopólisacárido de Escherichia coli O:26,B:6.

- N-(1-naftil)etilendiamina (NEDA)

- N-Lauroilsarcosina (Sarcosil)

- N, N, N', N'- tetrametilendiamina (TEMED)

- $\mathrm{N}^{\mathrm{G}}$-monometil-L-argininina

- Ortovanadato sódico

- Paranitrofenilfosfato (p-NPP)

- Persulfato de amonio

- Pirofosfato tetrasódico

- Tween 20

Watman International Ltd. (Maidstone, Reino Unido)

- Papel de filtro Whatman P81

\section{WASSERMANN}

- Estreptomicina 


\subsection{MEDIOS, TAMPONES Y SOLUCIONES}

\section{Tampón fosfato salino PBS 0,15 M}

$\begin{array}{ll}\mathrm{NaCl} & 8 \mathrm{~g} / \mathrm{l} \\ \mathrm{KCl} & 0.2 \mathrm{~g} / \mathrm{l} \\ \mathrm{Na}_{2} \mathrm{HPO}_{4} 7 \mathrm{H}_{2} \mathrm{O} & 11.5 \mathrm{~g} / \mathrm{l} \\ \mathrm{KH}_{2} \mathrm{PO}_{4} & 2 \mathrm{~g}\end{array}$

Medio de cultivo de los macrófagos

DMEM (con $4.5 \mathrm{~g} / \mathrm{l}$ de glucosa, sin rojo fenol ni L-glutamina) suplementado con:

$\begin{array}{ll}\text { L-Glutamina } & 2 \mathrm{mM} \\ \text { L-Arginina } & 0.5 \mathrm{mM} \\ \text { Gentamicina } & 50 \mu \mathrm{g} / \mathrm{ml} \\ \text { Penicilina } & 50 \mathrm{U} . \mathrm{I} . \mathrm{ml} \\ \text { Estreptomicina } & 50 \mu \mathrm{g} / \mathrm{ml}\end{array}$

Colorante de basófilos (azul de toluidina)(100 ml)

$1.0 \mathrm{~g}$ de borato sódico

$0.5 \mathrm{~g}$ de azul de toluidina

$\mathrm{H}_{2} \mathrm{O}$ destilada

Medio de cultivo de Luria-Bertani (LB)

$\begin{array}{ll}\text { Triptona } & 1 \% \mathrm{pH} 7.5 \\ \text { Extracto de levadura } & 0.5 \% \\ \mathrm{NaCl} & 1 \%\end{array}$

Tampón Tris-EDTA (TE)

$\begin{array}{ll}\text { Tris-HCl pH } 7.4 & 25 \mathrm{mM} \\ \text { EDTA } & 10 \mathrm{mM}\end{array}$




\section{Tampón para electroforesis de ADN Tris-Borato-EDTA (TBE) 5 X}

$\begin{array}{ll}\text { Tris } & 54 \mathrm{~g} / \mathrm{l} \\ \text { Ácido bórico } & 27.5 \mathrm{~g} / \mathrm{l} \\ \text { EDTA 0.5 M pH } 8 & 20 \mathrm{ml} / 1\end{array}$

\section{Solución de marcaje}

HEPES:TM:OL=25:25:7

- Hepes 1 M pH 6.6

- TM: 250mM TrisHcl pH 8

$25 \mathrm{mM} \mathrm{MgCl}$

$50 \mathrm{mM} \beta$-mercaptoetanol

- OL: 50 U hexámeros disueltos en $550 \mu \mathrm{l}$ de $1 \mathrm{mM}$ trisCl pH 8/1mM EDTA pH 8

\section{Solución D para extracción de ARN}

$\begin{array}{ll}\text { Tiocianato de guanidinio } & 4 \mathrm{M} \\ \text { Citrato sódico } & 25 \mathrm{mM} \\ \text { Sarcosil } & 0.5 \%\end{array}$

\section{Tampón de carga para ARN}

$\begin{array}{ll}\text { Formamida } & 50 \% \\ \text { MOPS } & 1 \mathrm{X} \\ \text { Glicerol } & 8 \% \\ \text { Formaldehido } & 2 \%\end{array}$

\section{Tampón MOPS $10 \mathrm{X}$}

$\begin{array}{ll}\text { MOPS } & 41.9 \mathrm{~g} / \mathrm{l} \\ \text { Acetato sódico anhidro } & 4.1 \mathrm{~g} / \mathrm{l} \\ \text { EDTA 0.5 M pH8 } & 10 \mathrm{ml} / \mathrm{l}\end{array}$

\section{Solución de lavado para el "Northern Blot"}
Tampón fosfato
$40 \mathrm{mM}$
SDS
$1 \%$ 
Solución de prehibridación para "Northern Blot"

$\begin{array}{ll}\text { Tampón fosfato } & 0.5 \mathrm{M} \mathrm{pH} 7.2 \\ \text { SDS } & 7 \% \\ \text { EDTA } & 1 \mathrm{mM}\end{array}$

Tampón de lisado celular para Western Blot

$\begin{array}{ll}\text { HEPES } & 50 \mathrm{mM} \mathrm{pH} 7.4 \\ \mathrm{NaCl} & 150 \mathrm{mM} \\ \text { Glicerol } & 10 \% \\ \text { Triton-X } 100 & 1 \% \\ \text { EDTA } & 1 \mathrm{mM} \\ \text { EGTA } & 1 \mathrm{mM} \\ \text { p-NPP } & 3 \mu \mathrm{M} \\ \text { Aprotinina } & 10 \mu \mathrm{g} / \mathrm{ml} \\ \text { Leupeptina } & 10 \mu \mathrm{g} / \mathrm{ml} \\ \text { PMSF } & 1 \mathrm{mM} \\ \text { Ortovanadato sódico } & 200 \mathrm{mM} \\ \text { Pirofosfato tetrasódico } & 10 \mathrm{mM} \\ \text { Fluoruro sódico } & 100 \mathrm{mM}\end{array}$

Tampón de Laemli para cargar muestras de proteínas en geles de poliacrilamida $(\mathbf{1 0 0} \mathbf{~ m l})$

$\begin{array}{ll}\text { Tris 0.5 M pH 6.8 } & 37.5 \mathrm{ml} \\ \text { Glicerol } & 35 \mathrm{ml} \\ \text { SDS } & 6 \mathrm{~g} \\ \text { DTT 1 M } & 2 \mathrm{ml} \\ \text { Azul de Bromofenol } & 6 \mathrm{mg}\end{array}$


Mezcla de acrilamida al $8 \%$ para Western Blot

$\begin{array}{ll}\mathrm{H}_{2} \mathrm{O} & 2.3 \mathrm{ml} \\ \text { Tris } 1.5 \mathrm{M} \mathrm{pH} 8.3 & 1.3 \mathrm{ml} \\ \text { Mezcla acrilamida } 30 \% & 1.3 \mathrm{ml} \\ \text { SDS } 10 \% & 50 \mu \mathrm{l} \\ \text { APS } 10 \% & 50 \mu \mathrm{l} \\ \text { TEMED } & 3 \mu \mathrm{l}\end{array}$

Tampón de electroforesis de proteínas 10 X (1 litro)

$\begin{array}{ll}\text { Glicina } & 144 \mathrm{~g} \\ \text { Tris } & 30 \mathrm{~g} \\ \text { SDS } & 10 \mathrm{~g}\end{array}$

Tampón de transferencia de proteínas (1 litro)

$\begin{array}{ll}\text { Glicina } & 14 \mathrm{~g} \\ \text { Tris } & 3 \mathrm{~g} \\ \text { SDS } 10 \% & 3 \mathrm{ml} \\ \text { Metanol } & 200 \mathrm{ml}\end{array}$

Tampón Tris salino con Tween-20 (TTBS) (1 litro)

$\begin{array}{ll}\text { Tris- } \mathrm{HCl} \mathrm{pH} 7.6 & 2.4 \mathrm{~g} \\ \mathrm{NaCl} & 8 \mathrm{~g} \\ \text { Tween-20 } & 0.5 \mathrm{ml}\end{array}$




\subsection{MÉTODOS EXPERIMENTALES}

\subsubsection{OBTENCIÓN DE LOS LIPOPOLISACÁRIDOS}

\subsubsection{Obtención de los S-LPSs de Brucella}

Hemos llevado a cabo este estudio con los S-LPSs de Brucella abortus 544 y de Brucella melitensis 16M.

La extracción de S-LPS se realizó por el método de Westphal y Jann (método del fenol caliente) modificado por Redfearn para Brucella $^{(260)}$ y hemos utilizado la fracción fenólica purificada según el método utilizado por Moreno et al. ${ }^{(261)}$

\section{Obtención de la fracción fenólica}

Se cultivaron 15 matraces con 20 litros en total de caldo brucella, los cuales se inocularon con B. melitensis $16 \mathrm{M}$ o B. abortus 544 a partir de un cultivo en fase lisa. Los matraces se incubaron en un arcón incubador orbital (New Brunswick) a $37^{\circ} \mathrm{C}$ durante 72 h y a $200 \mathrm{rpm}$. En el caso de B. abortus 544 se conectó al incubador una bombona con $10 \%$ de $\mathrm{CO}_{2}$ y $90 \%$ de aire dados los requerimientos de $\mathrm{CO}_{2}$ que presenta esta especie bacteriana. Una vez crecidos y comprobada la pureza de los cultivos se procedió a la muerte de las bacterias añadiendo fenol puro hasta que la concentración final en el matraz fuera del $0.5 \%$. Los matraces se incubaron durante 48 horas a $37^{\circ} \mathrm{C}$ con el fin de asegurar la muerte de todas las bacterias.

Los caldos crecidos y con las brucelas muertas fueron centrifugados a $6000 \mathrm{rpm}$ para recuperar los cuerpos bacterianos. Posteriormente se procedió al lavado de los mismos en $\mathrm{H}_{2} \mathrm{O}$ destilada y a su resuspensión en $\mathrm{H}_{2} \mathrm{O}$ a la proporción aproximada de $5 \mathrm{~g}$ de bacterias / $170 \mathrm{ml}$ de $\mathrm{H}_{2} \mathrm{O}$. La suspensión de brucelas se calentó a $66^{\circ} \mathrm{C}$ al baño maría y se añadió un volumen igual de fenol precalentado a $66^{\circ} \mathrm{C}$. La mezcla se agitó constante y vigorosamente con agitador de varilla durante $15 \mathrm{~min}$ a $66^{\circ} \mathrm{C}$ en el baño maría. Una vez finalizada la mezcla fenol-bacterias fue enfriada rápidamente por inmersión del matraz en baño de hielo. La mezcla se centrifugó a $15000 \mathrm{rpm}$ durante $20 \mathrm{~min}$ a 4 $\mathrm{C}$, tras lo cual se extrajo la fase fenólica. La fase fenólica fue filtrada a través de papel de filtro Whatman $n^{\circ} 2$ con el fin de eliminar los restos celulares, para lo cual utilizamos un matraz de Kitasato conectado al vacío y con un embudo con soporte de cristal poroso para sujetar el papel de filtro. Aplicamos una ligera presión negativa para ayudar a la 
filtración. De este modo pasa sólo la fracción fenólica quedando los restos de ácidos nucleicos y celulares en el papel de filtro.

Para la extracción y purificación del SLPS de B. melitensis $16 \mathrm{M}$ se precipitó la fase fenólica con 3 volúmenes de metanol con $1 \%$ de metanol saturado con acetato sódico y se dejó precipitar toda la noche a $-20^{\circ} \mathrm{C}$. El precipitado fue recuperado por centrifugación a $13000 \mathrm{rpm}$ durante $20 \mathrm{~min}$ y posteriormente fue redisuelto en agua destilada dejándose en agitación toda la noche. El SLPS se recuperó por centrifugación a partir del sobrenadante, quedando en el sedimento ácidos nucleicos, restos de pared celular etc.

Con el sobrenadante se procedió a una nueva precipitación en metanol con $1 \%$ de metanol saturado con acetato sódico y una vez redisuelto el precipitado con el SLPS y centrifugado para eliminar los restos de impurezas, el S-LPS fue dializado frente a 50 volúmenes de agua destilada durante 3 días y con 3 cambios de dializante. El S-LPS resultante (S-LPS bruto) fue liofilizado.

Para la obtención del S-LPS de B. abortus 544 se procedió de la misma forma con la diferencia que se utilizaron 4 volúmenes de metanol con $1 \%$ de metanol saturado con acetato sódico en lugar de los 3 volúmenes utilizados para $B$. melitensis.

\section{Obtención de la fracción fenólica purificada}

Para la purificación de la fracción fenólica se siguió el método utilizado por Moreno et al. ${ }^{(261)}$. El S-LPS bruto se disolvió a razón de $5 \mathrm{mg}$ por $\mathrm{ml}$ de DMSO, agitándolo a temperatura ambiente durante $20 \mathrm{~min}$ en agitador magnético. Posteriormente se añadió, agitando lentamente la solución, un volumen igual de INa 4M y la mezcla se mantuvo en agitación a temperatura ambiente durante $20 \mathrm{~min}$. El S-LPS se obtuvo por precipitación con metanol a $-20^{\circ} \mathrm{C}$ agitando durante $1 \mathrm{~h}$. El precipitado con el S-LPS se recogió por centrifugación a $15000 \mathrm{rpm}$ durante $30 \mathrm{~min}$ y se redisolvió de nuevo en DMSO, repitiendo el tratamiento completo 5 veces más. Con el último precipitado se procedió a su diálisis y liofilización.

El S-LPS así tratado fue disuelto en $2.5 \mathrm{ml}$ de 0.05 Tris-ClH a pH 8.1 con $2 \mathrm{M}$ INa y $5 \%$ Tween, cromatografiado en Sephadex G 200, obteniéndose la fracción purificada de S-LPS en el volumen de exclusión. 
El S-LPS fue controlado mediante la inmunoelectroforesis en agarosa al $1.5 \%$ en tampón veronal a pH 8.6 frente a un antisuero anti-S-LPS obtenido por inoculación en conejo de S-LPS de B. melitensis.

El análisis de estos lipopolisacáridos fue amablemente realizado por el profesor Dr. I. Moriyón de la Universidad de Navarra obteniéndose el siguiente contenido en KDO: LPS de E. coli: $1.6 \%$; S-LPS de B. abortus 544 (fracción fenólica purificada): $0.70 \%$; S-LPS de B. melitensis (fracción fenólica purificada): $0.79 \%$.

\subsubsection{Obtención de los lípidos A y polisacáridos $\mathbf{O}$}

Los lípidos A de B. abortus, B. melitensis y E. coli y el polisacárido O de B. abortus se obtuvieron por hidrólisis ácida de los LPS obtenidos según se ha descrito anteriormente siguiendo el método utilizado por Moreno et al. ${ }^{(262)}$.

Para la hidrólisis de los S-LPSs, éstos se disolvieron en ácido acético al $2 \%$ (50 mg del S-LPS en $5 \mathrm{ml}$ de ácido acético) y se incubaron al baño maría en ebullición.

El LPS de E. coli se mantuvo durante $1 \mathrm{~h}$ en ebullición, mientras que los S-LPSs de Brucella fueron mantenidos en ebullición durante $5 \mathrm{~h}$.

Una vez finalizada la ebullición, las muestras fueron centrifugadas a 9000 x g durante $30 \mathrm{~min}$. El polisacárido $\mathrm{O}$ junto con restos de cadena $\mathrm{O}$ se obtuvo liofilizando el sobrenadante.

El precipitado, con contenido mayoritario de lípido A, fue lavado 6 veces en agua bidestilada. Por último el lípido A fue resuspendido en $5 \mathrm{ml}$ de agua bidestilada y solubilizado añadiendo $10 \mu \mathrm{l}$ de trietilamina. Los restos insolubles fueron eliminados por centrifugación a 9000 x g durante $30 \mathrm{~min}$.

La trietilamina sobrante fue eliminada de la solución de lípido A por filtración en Sephadex G10 embebido en agua bidestilada. La solución de lípido A fue liofilizada.

\subsubsection{Otros lipopolisacáridos utilizados}

- El LPS de Escherichia coli O:26,B:6 se obtuvo comercialmente.

- Los lipopolisacáridos de Escherichia hermannii, Yersinia enterocolitica O:9, Pseudomonas (Xanthomonas) maltophilia 555 y Ochrobactrum anthropi LMG 3331 fueron generosamente cedidos por el Dr. I. Moriyón. 


\subsubsection{OBTENCIÓN DE MACRÓFAgOS PERITONEALES DE RATA}

Justo antes de la extracción se preparó para cada rata una jeringa de $50.0 \mathrm{ml}$ con PBS+EDTA(2mM) estéril, manteniéndolas en hielo. Tras anestesiar las ratas con éter dietílico se mataron por dislocación cervical, y en condiciones asépticas se retiró la piel del abdomen, inyectándose en la cavidad peritoneal el contenido de la jeringa. Tras ligero masaje, se recogieron las células peritoneales extrayendo con la jeringa la máxima cantidad posible de solución. Después de centrifugar a $4^{\circ} \mathrm{C}$ durante $10 \mathrm{~min}$ a $400 \mathrm{x}$ g, las células se resuspendieron en el volumen adecuado de DMEM. El volumen de DMEM a añadir se determinó tras el recuento celular en microscopio óptico con una cámara Malassez utilizando azul de toluidina, para así ajustar la concentración de células. Para la obtención de las monocapas de macrófagos adherentes, se distribuyeron en placas de cultivo y se dejaron adherir durante $2 \mathrm{~h}$ a $37^{\circ} \mathrm{C}$ en una atmósfera de $10 \%$ de $\mathrm{CO}_{2}$. Transcurrido ese tiempo, las placas se lavaron dos veces con $\mathrm{PBS}$ a $37^{\circ} \mathrm{C}$ para eliminar las células no adherentes y se añadió medio fresco completo.

\subsubsection{MEDIDA DE LA PRODUCCIÓN DE NO}

Para determinar el NO liberado por los macrófagos peritoneales se midió la acumulación de nitritos según el método de Griess ${ }^{(263)}$. Se utilizaron placas de 24 pocillos con $1.5 \times 10^{6}$ células $/ \mathrm{ml}$ de medio de cultivo de macrófagos. Finalizado el tiempo de estimulación de las células con los distintos lipopolisacáridos o lípidos A, se añadió ácido sulfanílico $1 \mathrm{mM}$ y $\mathrm{HCl} 100 \mathrm{mM}$ (concentraciones finales). Después de una incubación de $5 \min$ a temperatura ambiente, se añadió $\mathrm{N}$-1-naftiletilendiamina para tener una concentración final $1 \mathrm{mM}$. Se dejaron transcurrir $15 \mathrm{~min}$ para que se completara la reacción con la formación de un cromóforo, y a continuación, se midió por colorimetría la concentración de nitritos en los sobrenadantes a una longitud de onda de $548 \mathrm{~nm}$ comparando con una recta patrón preparada con concentraciones conocidas de $\mathrm{NaNO}_{2}$. La producción de $\mathrm{NO}$ se expresó en nanomoles de $\mathrm{NO}_{2}{ }^{-} / \mathrm{mg}$ proteína. La cantidad de proteína se determinó por el método de Bradford ${ }^{(264)}$ utilizando el reactivo Bio-Rad Protein Assay. Cada prueba se realizó un mínimo de 5 veces y todos los ensayos se realizaron por duplicado. 


\subsubsection{EXTRACCIÓN DE ARN TOTAL}

La extracción del ARN total de las células se realizó siguiendo el método puesto a punto por Chomczynski y Sacchi ${ }^{(265)}$. Este método permite lisar las células con gran rapidez en presencia de agentes desnaturalizantes muy potentes que inhiben las ARNasas, evitando así la degradación del ARN.

A cada placa de $35 \mathrm{~mm}$, a la que se habían adherido aproximadamente $10^{7}$ células, se añadieron $0,5 \mathrm{ml}$ de solución $\mathrm{D}, 20 \mu \mathrm{l}$ de $\beta$-mercaptoetanol 1M, $50 \mu \mathrm{l}$ de acetato sódico $3 \mathrm{M} \mathrm{pH} \mathrm{4,5} \mathrm{y} \mathrm{0,5} \mathrm{ml} \mathrm{de} \mathrm{fenol} \mathrm{ácido.} \mathrm{El} \mathrm{lisado} \mathrm{celular} \mathrm{se} \mathrm{transfirió} \mathrm{a} \mathrm{un} \mathrm{tubo} \mathrm{Eppendorf} \mathrm{al}$ que seguidamente se le añadieron $100 \mu \mathrm{l}$ de cloroformo/alcohol isoamílico (24:1). Tras agitación vigorosa en el vortex durante 15 segundos, los tubos se incubaron 15 min en hielo. A continuación, se centrifugaron durante $15 \mathrm{~min}$ a $12000 \mathrm{~g}, 4^{\circ} \mathrm{C}$ y se tomó la fase superior, que se transfirió a otro tubo Eppendorf. Tras añadir 1 volumen de isopropanol se guardaron los tubos a $-20^{\circ} \mathrm{C}$ durante $2 \mathrm{~h}$, para que el ARN precipitase. Transcurrido ese tiempo, los tubos se centrifugaron durante $15 \mathrm{~min}$ a $15000 \mathrm{~g}, 4^{\circ} \mathrm{C}$, se desechó el sobrenadante y se lavó el precipitado con $1 \mathrm{ml}$ de etanol al $70 \%$. Se centrifugó de nuevo, brevemente, a la misma velocidad y temperatura y se volvió a eliminar el sobrenadante. El precipitado se dejó secar un momento a temperatura ambiente y se disolvió en $\mathrm{H}_{2} \mathrm{O}$ tratada con DEPC $(0.1 \%)^{(266)}$.

La cantidad de ARN presente en cada muestra se determinó por espectrofotometría midiendo las absorbancias a 260 y $280 \mathrm{~nm}$, longitudes a las que presentan la máxima absorbancia los ácidos nucleicos y las proteínas, respectivamente. El cociente $\mathrm{A}_{60} / \mathrm{A}_{280}$ indica la pureza del ARN. Se considera que las muestras son adecuadas cuando los valores de ese cociente están comprendidos entre 1,8 y 2 .

La concentración de ARN en mg/ml se calculó mediante la siguiente fórmula:

$[\mathrm{ARN}]_{\mathrm{mg} / \mathrm{ml}}=\mathrm{A}_{260} \times$ factor de dilución x 40 (factor de absorbancia del ARN)

\subsubsection{OBTENCIÓN Y MARCAJE DE LAS SONDAS}

\subsubsection{Obtención de las sondas}

La sonda de DNA específica para iNOS fue obtenida a partir células de $E$. coli DH5 $\alpha$, transformadas con el plásmido pBS(BlueScript)-NOS-695, que contiene una secuencia específica para la iNOS de macrófagos de ratón de 695 pares de bases (pb), 
células generosamente cedidas por el Dr. Lisardo Boscá. Se extrajo el DNA plasmídico por lisis alcalina ${ }^{(267)}$ seguida de distintas extracciones y purificaciones. Se inoculó $1 \mathrm{ml}$ de cultivo fresco en $100 \mathrm{ml}$ de medio LB con $50 \mu \mathrm{g} / \mathrm{ml}$ de ampicilina. Tras incubación toda la noche a $37^{\circ} \mathrm{C}$ en agitación, se centrifugó 15 min a 3000 r.p.m., $4^{\circ} \mathrm{C}$ resuspendiendo las bacterias en $5 \mathrm{ml}$ de TE. Las siguientes centrifugaciones se realizaron en las mismas condiciones salvo que se indique lo contrario. A continuación se añadieron $10 \mathrm{ml}$ de SDS $1 \% / \mathrm{NaOH} 0.2 \mathrm{~N}$ recién preparado, agitando suavemente y se ńncubó en hielo durante $20 \mathrm{~min}$. Tras esto se añadieron $7.5 \mathrm{ml}$ de acetato potásico $3 \mathrm{M}$ / ácido fórmico $1.8 \mathrm{M}$, incubándose nuevamente en hielo $10 \mathrm{~min}$. De esta forma se provocó el cierre covalente del ADN plasmídico, precipitando la mayoría del ADN cromosómico y proteínas, así como el SDS. Se centrifugó, y al sobrenadante se añadieron $10 \mathrm{ml}$ de isopropanol. Después de centrifugar, el precipitado se disolvió en 2 $\mathrm{ml}$ de $\mathrm{H}_{2} \mathrm{O}$ al que se añadieron $2 \mathrm{ml}$ de ClLi 5M, incubándose $30 \mathrm{~min}$ en hielo. Se volvió a centrifugar $5 \mathrm{~min}$, y al sobrenadante, se añadieron $9 \mathrm{ml}$ de etanol, y tras $10 \mathrm{~min}$ en hielo se centrifugó 10 min. El precipitado se disolvió en $350 \mu \mathrm{l}$ de TE y se pasó a un tubo Eppendorf. Se extrajo dos veces con $350 \mu$ de la mezcla fenol (básico)/cloroformo mediante agitación, incubación $10 \mathrm{~min}$ en hielo y centrifugación $10 \mathrm{~min}$ a $12500 \mathrm{rpm}$, $4^{\circ} \mathrm{C}$. Se extrajo la fase superior acuosa, para finalmente añadir $1 / 2$ volumen de acetato amónico $7.5 \mathrm{M}$ y 2 volúmenes de etanol. Después de mezclarlos y centrifugarlos a $15000 \mathrm{rpm}, 4^{\circ} \mathrm{C}$, durante $5 \mathrm{~min}$ el precipitado se lavó con $1 \mathrm{ml}$ de etanol $70 \%$. Tras una nueva centrifugación a la misma velocidad y temperatura se volvió a desechar el sobrenadante. El precipitado se dejó secar un momento a temperatura ambiente y se disolvió en $50 \mu \mathrm{l}$ de TE. Con $1 \mu \mathrm{l}$ se realizó una electroforesis en gel de agarosa al $1 \%$ en TBE 0.5 X, utilizando como marcador el ADN del fago Lambda digerido con HindIII, comprobándose que habíamos extraído el ADN plasmídico (3590 pb). Para eliminar restos de ARN se trató con ARNasa $\left(37^{\circ} \mathrm{C}, 16 \mathrm{~h}\right)$, volviendo a proceder de igual modo que desde la extracción con fenol-cloroformo. Con una nueva electroforesis se comprobó que teníamos el ADN plasmídico purificado.

Para la reacción de digestión se pusieron los $50 \mu$ de TE conteniendo el ADN plasmídico con $10 \mu \mathrm{l}$ de la enzima de restricción BamHI, $10 \mu \mathrm{l}$ buffer E (10X) y $30 \mu \mathrm{l}$ de $\mathrm{H}_{2} \mathrm{O}$ estéril, incubándose a $37^{\circ} \mathrm{C}$ toda la noche. Con un nuevo gel comprobamos que se han formado dos fragmentos uno de 2895 pb y otro de 695 pb (sonda iNOS). 
En un gel de agarosa al $1 \%$ en TBE $0.5 \mathrm{X}+1 \mu \mathrm{l}$ de BrEt se llevó a cabo la electroforesis de los $50 \mu$ l donde está el plásmido digerido y se procedió a la extracción y purificación del fragmento de 695 pb (sonda) por el método GENECLEAN II.

La sonda de $\beta$-actina utilizada es un fragmento EcoRI/HindIII de $644 \mathrm{pb}$ aislado del vector VC18 generosamente proporcionado por el Dr. M. Sánchez Crespo.

\subsubsection{Marcaje de las sondas}

Se realizó por el método de random priming ${ }^{(268)}$. Así 50 ng de sonda en un volumen de $12 \mu \mathrm{l}$ se hirvieron durante $10 \mathrm{~min}$. Se colocó en hielo y se añadieron $18 \mu \mathrm{lde}$ solución de marcaje, $2 \mu \mathrm{l}$ de BSA (16mg/ml), $3 \mu \mathrm{l}$ de la mezcla dNTP 100 $\mu \mathrm{M}, 1 \mu \mathrm{l}$ de la enzima Klenow (0.5-1 U) y $5 \mu$ de $\left[\alpha-{ }^{32} \mathrm{P}\right] \mathrm{dCTP}$. Se dejó toda la noche a temperatura ambiente, tras lo cual se añadieron $2 \mu \mathrm{l}$ de EDTA $0.5 \mathrm{M}$ pH 8, $4 \mu \mathrm{l}$ ARNt (10mg/ml), $22 \mu \mathrm{l}$ de $\mathrm{NH}_{4} \mathrm{Ac} 7.5 \mathrm{M}$ y $150 \mu \mathrm{l}$ de etanol. Tras $5 \mathrm{~min}$ a temperatura ambiente se centrifugó durante $5 \mathrm{~min}$, lavándose el precipitado con $150 \mu \mathrm{l}$ de etanol $70 \%$; se dejó secar el precipitado y se disolvió en $100 \mu \mathrm{l}$ de TE, comprobando en un contador beta que se había producido el marcaje. Se desnaturalizó la sonda con $\mathrm{NaOH} 0.4$ M, 10 min, mezclándose a continuación con $15 \mathrm{ml}$ de tampón de prehibridación.

\subsubsection{Northern Blot}

Se tomaron $10 \mu \mathrm{g}$ de ARN extraído y se desnaturalizaron en el tampón de carga durante 10 min a $65^{\circ} \mathrm{C}$. A continuación, el ARN se separó mediante electroforesis en un gel compuesto por agarosa al $0,9 \%$, formaldehído al $2 \%$ y MOPS $1 \mathrm{X}^{(266)}$ y se transfirió por capilaridad a una membrana de nilón Nytran. La membrana se prehibridó con la solución de prehibridación durante $1 \mathrm{~h} \mathrm{a} 65^{\circ} \mathrm{C}$ y seguidamente se hibridó durante toda la noche ${ }^{(269)}$ con la sonda de iNOS marcada. A continuación, la membrana se lavó 3 veces con la solución de lavado, una vez a temperatura ambiente durante $5 \mathrm{~min}$ y dos veces a $65^{\circ} \mathrm{C}$ durante $10 \mathrm{~min}$. Finalmente, la membrana se expuso con una película de rayos $\mathrm{X}$, a $-70^{\circ} \mathrm{C}$, para obtener una autoradiografía. La membrana también se hibridó con una sonda de $\beta$-actina para demostrar la integridad del ARN, la equivalencia de carga en todas las calles y la especificidad de la inducción. 


\subsubsection{Inmunodetección (Western Blot)}

Se utilizaron también placas de $35 \mathrm{~mm}$ con aproximadamente $10^{7}$ células adheridas. Tras la estimulación, se quitó el medio y se lavaron dos veces con PBS frío, lisándose con $100 \mu \mathrm{l}$ de tampón de lisis de Western Blot. Se pasó el lisado celular a un tubo Eppendorf que se incubó en hielo un mínimo de 30 min tras los cuales se centrifugó a 10000 x g durante $10 \mathrm{~min}, 4^{\circ} \mathrm{C}$. Se descartó el precipitado, determinándose la cantidad de proteína de cada muestra por el método de Bradford ${ }^{(264)}$. Las muestras se mezclaron con tampón de Laemmli (1X final) y DTT (20 $\mathrm{mM}$ final), hirviéndose $5 \mathrm{~min}$ y centrifugándose otros 5 min a 10000 x g. A continuación se realizó una electroforesis en gel de SDS-8 \% poliacrilamida, cargándose igual cantidad de proteína (40 $\mu \mathrm{g}$ ) en cada pocillo, además de marcadores de peso molecular que nos ayudaron a situar en el gel la iNOS $(130 \mathrm{kD})$.

Tras finalizar la electroforesis, se efectuó la transferencia de las proteínas del gel a una membrana de nitrocelulosa. La transferencia se realizó en tampón de transferencia utilizando el módulo de transferencia de Bio-Rad. Las membranas transferidas se bloquearon con BSA al $5 \%$ en TTBS $(\mathrm{p} / \mathrm{v})$ durante $2 \mathrm{~h}$ y a continuación se hicieron dos lavados de $15 \mathrm{~min}$ con TTBS. Se incubó la membrana con el anticuerpo primario (anticuerpo de conejo contra la iNOS de rata) diluido adecuadamente(1/2000) en TTBS con BSA al $5 \%(\mathrm{p} / \mathrm{v})$ durante toda la noche a $4^{\circ} \mathrm{C}$. Seguidamente, se hicieron 4 lavados de 15 min con TTBS y la membrana se incubó con el anticuerpo secundario (anticuerpo de burro anti-IgG de conejo conjugado con peroxidasa de rábano) diluido adecuadamente (1/1000) en TTBS durante $1 \mathrm{~h}$ a temperatura ambiente. Finalizada esta incubación, la membrana se lavó durante otros cuatro periodos de 15 min con TTBS. La detección de las proteínas se realizó con el sistema de aumento de quimioluminiscencia de Amersham (kit ECL).

\subsubsection{Análisis de los datos}

El test de Student se utilizó para la comparación de medias. El análisis de la varianza (ANOVA) seguido del test de Bonferroni se empleó cuando se realizaron múltiples comparaciones. Se consideró significación estadística un valor de $\mathrm{p}<0.05$. 


\section{RESULTADOS}




\subsection{INDUCCIÓN DE LA PRODUCCIÓN DE NO POR LOS LPSs DE Escherichia coli, Brucella abortus y Brucella melitensis}

La capacidad para inducir la producción de óxido nítrico por los diferentes lipopolisacáridos se determinó en macrófagos peritoneales de rata, células seleccionadas porque en ellas se expresa en alto grado la isoforma inducible de la óxido nítrico sintasa $(\mathrm{iNOS})^{(270)}$.

Los lipopolisacáridos de E. coli, B. abortus y B. melitensis inducen la producción de óxido nítrico en las células adherentes peritoneales, medida como acumulación de nitrito y expresada como nanomoles/miligramo de proteína. Los resultados obtenidos tras 24 horas de incubación de los macrófagos peritoneales con los distintos lipopolisacáridos a las diferentes concentraciones utilizadas quedan reflejados en la tabla 4.1.

Tabla 4.1. Producción de NO por las células adherentes peritoneales estimuladas 24 h con los LPSs de $E$. coli, B. abortus y B. melitensis a diferentes concentraciones. Los resultados se expresan como nmoles/mg proteína. Cada valor representa la media \pm SEM (error estándar de la media) de 5 experimentos realizados cada uno por duplicado.

\begin{tabular}{|c|c|c|c||}
\hline $\begin{array}{c}\text { LPS } \\
(\boldsymbol{\mu g} / \mathbf{m l})\end{array}$ & $\begin{array}{c}\text { Escherichia } \\
\text { coli }\end{array}$ & $\begin{array}{c}\text { Brucella } \\
\text { abortus }\end{array}$ & $\begin{array}{c}\text { Brucella } \\
\text { melitensis }\end{array}$ \\
\hline Blanco & $54.0 \pm 3.9$ & $54.0 \pm 3.9$ & $54.0 \pm 3.9$ \\
\hline $\mathbf{0 . 0 0 1}$ & $59.2 \pm 1.9$ & $60.1 \pm 3.7$ & $53.7 \pm 1.9$ \\
\hline $\mathbf{0 . 0 1}$ & $75.6 \pm 2.3$ & $57.8 \pm 3.2$ & $60.2 \pm 2.2$ \\
\hline $\mathbf{0 . 1}$ & $92.6 \pm 4.7$ & $61.1 \pm 4.3$ & $73.4 \pm 3.9$ \\
\hline $\mathbf{1}$ & $108.7 \pm 2.7$ & $91.9 \pm 4.2$ & $100.3 \pm 4.4$ \\
\hline $\mathbf{1 0}$ & $114.0 \pm 4.6$ & $110.6 \pm 2.4$ & $102.6 \pm 5.2$ \\
\hline
\end{tabular}

\subsubsection{Curvas dosis-respuesta}

La producción de óxido nítrico inducida por los lipopolisacáridos de E. coli, B. abortus y B. melitensis es dosis dependiente. 


\subsubsection{LPS de Escherichia coli}

El LPS de Escherichia coli induce una producción de NO que es dosis dependiente, como apreciamos en la figura 4.1. Aunque la producción de óxido nítrico por el LPS de E. coli está suficientemente descrita ${ }^{(271)}$ nosotros lo hemos utilizado como control de nuestro sistema celular y para establecer comparaciones con los S-LPS de Brucella. Así en los macrófagos peritoneales de rata vemos como la incubación durante $24 \mathrm{~h}$ con diferentes concentraciones del LPS de E. coli induce un nivel de producción de NO superior a las células blanco ( $\sin$ LPS), aumentando la cantidad de NO producido desde la concentración de $0.001 \mu \mathrm{g} / \mathrm{ml}$ hasta la concentración de $1 \mu \mathrm{g} / \mathrm{ml}$. A partir de $1 \mu \mathrm{g} / \mathrm{ml}$ se alcanza el nivel máximo de producción de NO.

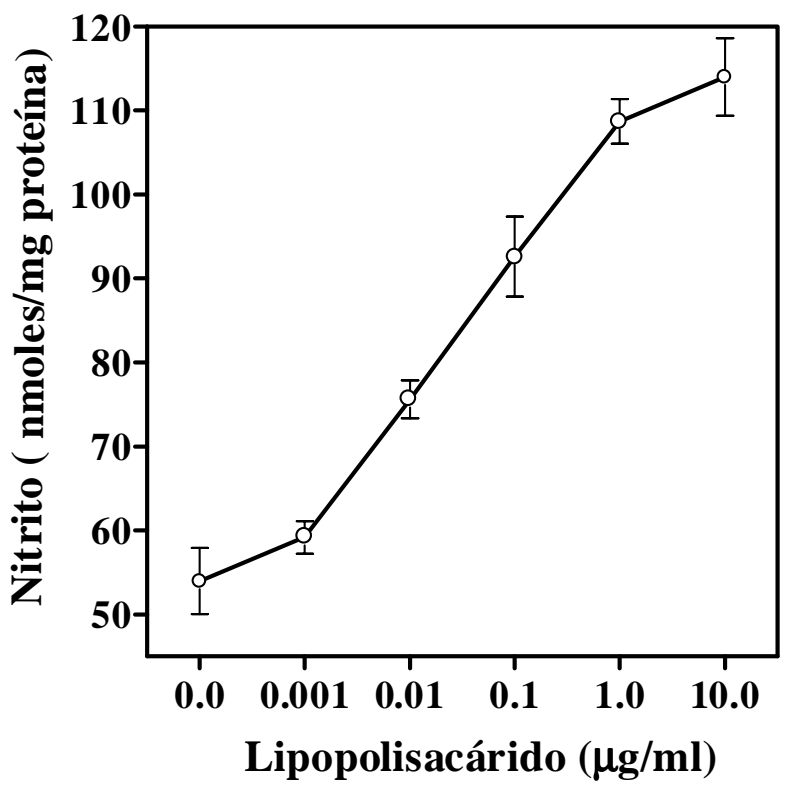

Figura 4.1. CURVA DOSIS-RESPUESTA DEL LPS DE Escherichia coli

\subsubsection{S-LPS de Brucella abortus}

En el caso de la estimulación durante 24 h con el S-LPS de B. abortus 544, es capaz de inducir la producción de NO, si bien no se aprecian diferencias con el nivel de NO producido por las células blanco (sin S-LPS) hasta la concentración de $0.1 \mu \mathrm{g} / \mathrm{ml}$ (inclusive). A partir de esta concentración se produce un incremento en la producción de NO que es máxima a la concentración de $10 \mu \mathrm{g} / \mathrm{ml}$ (figura 4.2.). 




Figura 4.2. CURVA DOSIS-RESPUESTA DEL S-LPS DE Brucella abortus

\subsubsection{S-LPS de Brucella melitensis}

El S-LPS de B. melitensis $16 \mathrm{M}$ también induce una producción de NO dosis dependiente tras $24 \mathrm{~h}$ de estimulación (figura 4.3.), existiendo un aumento en el nivel de NO inducido desde la concentración de $0.01 \mu \mathrm{g} / \mathrm{ml}$ hasta la concentración de $1 \mu \mathrm{g} / \mathrm{ml}$. A partir de $1 \mu \mathrm{g} / \mathrm{ml}$ de LPS no existe un aumento en la producción de NO.

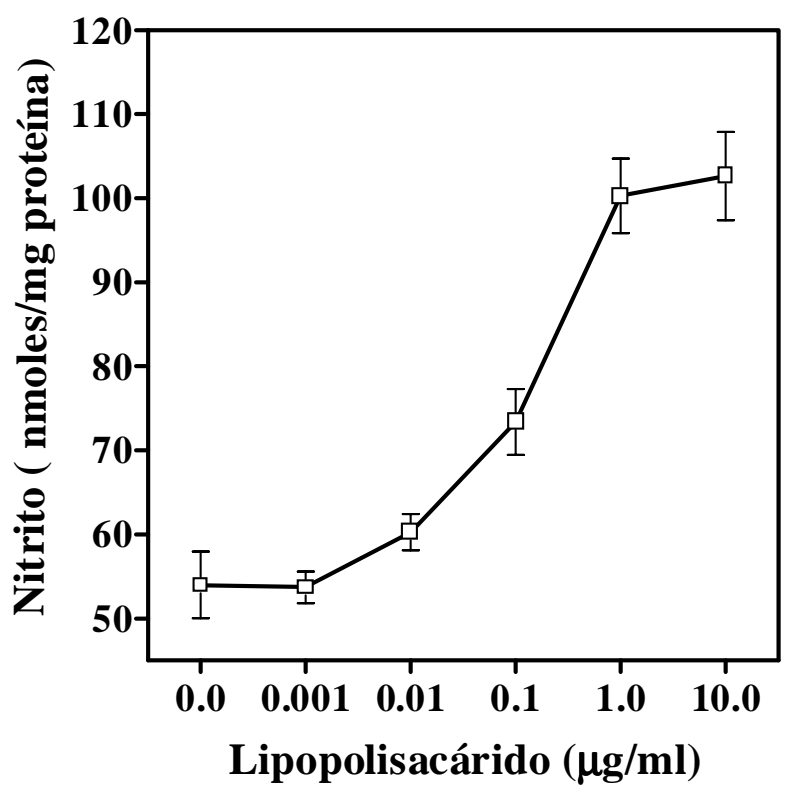

Figura 4.3. CURVA DOSIS-RESPUESTA DEL S-LPS DE Brucella melitensis 


\subsubsection{Comparación del nivel de NO inducido por los LPSs de E. coli, B. abortus y B. melitensis}

En la figura 4.4. representamos el nivel de NO inducido por los macrófagos incubados $24 \mathrm{~h}$ con las distintas concentraciones de estos tres lipopolisacáridos. Los S-LPSs de Brucella abortus y Brucella melitensis son inductores menos potentes de la producción de NO a dosis bajas, y así a la concentración de $0.01 \mu \mathrm{g} / \mathrm{ml}$ no producen NO a un nivel significativo con respecto al blanco, mientras que el LPS de Escherichia coli sí presenta a dicha concentración un nivel significativamente superior. Para alcanzar niveles de NO similares a los inducidos por el LPS de E. coli a la concentración de $0.1 \mu \mathrm{g} / \mathrm{ml}$ necesitamos 10 veces más concentración $(1 \mu \mathrm{g} / \mathrm{ml})$ de los lipopolisacáridos de Brucella. Sin embargo, a la concentración máxima utilizada $(10 \mu \mathrm{g} / \mathrm{ml})$ los tres LPSs inducen un nivel similar de NO.

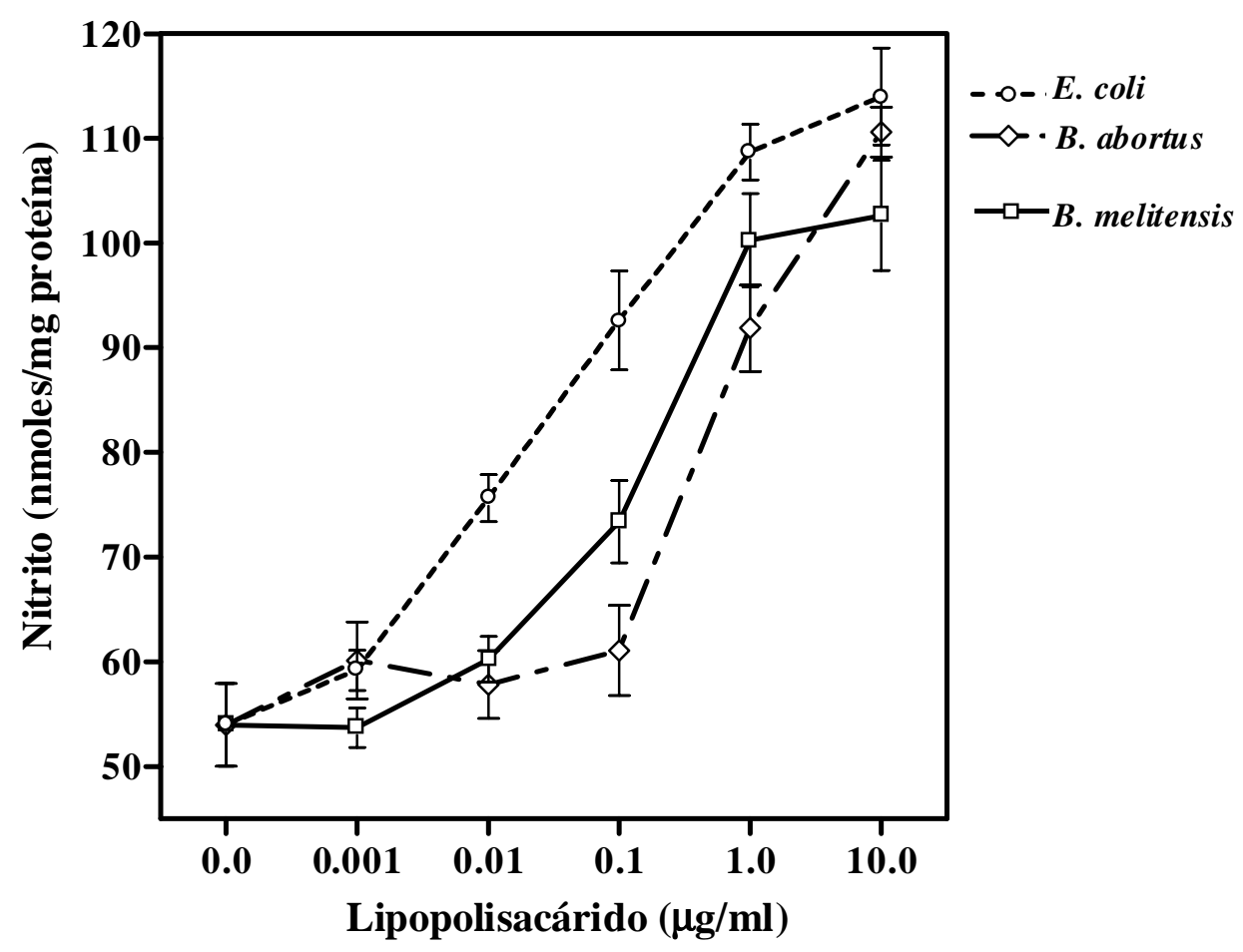

Figura 4.4. INDUCCIÓN DE NO POR LOS LPSs DE E. coli, B. abortus y B. melitensis

Comparando los niveles de NO producidos por los macrófagos peritoneales tras la exposición $24 \mathrm{~h}$ a estos tres lipopolisacáridos, observamos que a la dosis de $0.01 \mu \mathrm{g} / \mathrm{ml}$ el nivel de NO inducido por el LPS de E. coli es significativamente superior al inducido por el S-LPS de B. abortus $(\mathrm{p}<0.01)$ y al inducido por el S-LPS de B. melitensis 
(p<0.05). A la concentración de $0.1 \mu \mathrm{g} / \mathrm{ml}$ el LPS de E. coli también se muestra como un inductor más potente, con un nivel de NO significativamente superior al inducido por el S-LPS de B. abortus $(\mathrm{p}<0.001)$ y al inducido por el S-LPS de B. melitensis $(\mathrm{p}<0.01)$. Así mismo a la concentración de $1 \mu \mathrm{g} / \mathrm{ml}$ existen diferencias significativas $(\mathrm{p}<0.05)$ entre el S-LPS de B. abortus y el LPS de E. coli. No existen diferencias significativas $(\mathrm{p}>0.05)$ a ninguna concentración, entre los lipopolisacáridos de B. abortus y B. melitensis.

\subsubsection{Cinética de inducción de la producción del NO por los LPSs de E. coli, B. abortus y B. melitensis}

Para llevar a cabo este experimento, las células adherentes peritoneales se incubaron con los distintos lipopolisacáridos a una concentración fija de $1 \mu \mathrm{g} / \mathrm{ml}$ a la que los tres presentaban un nivel de inducción de la producción de NO significativamente superior al producido por las células blanco. A los tiempos indicados se midió el NO como nitrito con el reactivo de Griess expresando como siempre el resultado como nanomoles de nitrito/mg de proteína. Los resultados aparecen recogidos en la tabla 4.2. y representan la media \pm SEM de 3 experimentos, realizados cada uno de ellos por duplicado.

Tabla 4.2. Cinéticas de inducción de NO por los LPSs de E. coli, B. abortus y B. melitensis.

\begin{tabular}{||c|c|c|c|c||}
\hline $\begin{array}{c}\text { Tiempo } \\
\text { (horas) }\end{array}$ & blanco & $\begin{array}{c}\text { Escherichia } \\
\text { coli }\end{array}$ & $\begin{array}{c}\text { Brucella } \\
\text { abortus }\end{array}$ & $\begin{array}{c}\text { Brucella } \\
\text { melitensis }\end{array}$ \\
\hline $\mathbf{0}$ & $4.0 \pm 1.4$ & $4.0 \pm 1.4$ & $4.0 \pm 1.4$ & $4.0 \pm 1.4$ \\
\hline $\mathbf{2}$ & $8.0 \pm 2.2$ & $8.3 \pm 0.1$ & $8.0 \pm 0.5$ & $8.9 \pm 0.4$ \\
\hline $\mathbf{4}$ & $9.8 \pm 1.8$ & $11.5 \pm 0.4$ & $10.1 \pm 0.6$ & $9.7 \pm 0.7$ \\
\hline $\mathbf{8}$ & $21.7 \pm 4.1$ & $31.9 \pm 1.6$ & $25.6 \pm 1.3$ & $29.9 \pm 2.6$ \\
\hline $\mathbf{2 0}$ & $49.8 \pm 3.6$ & $100.0 \pm 5.2$ & $81.6 \pm 4.0$ & $86.1 \pm 4.0$ \\
\hline $\mathbf{2 4}$ & $56.3 \pm 3.7$ & $120.0 \pm 5.2$ & $96.4 \pm 3.0$ & $111.4 \pm 5.3$ \\
\hline
\end{tabular}




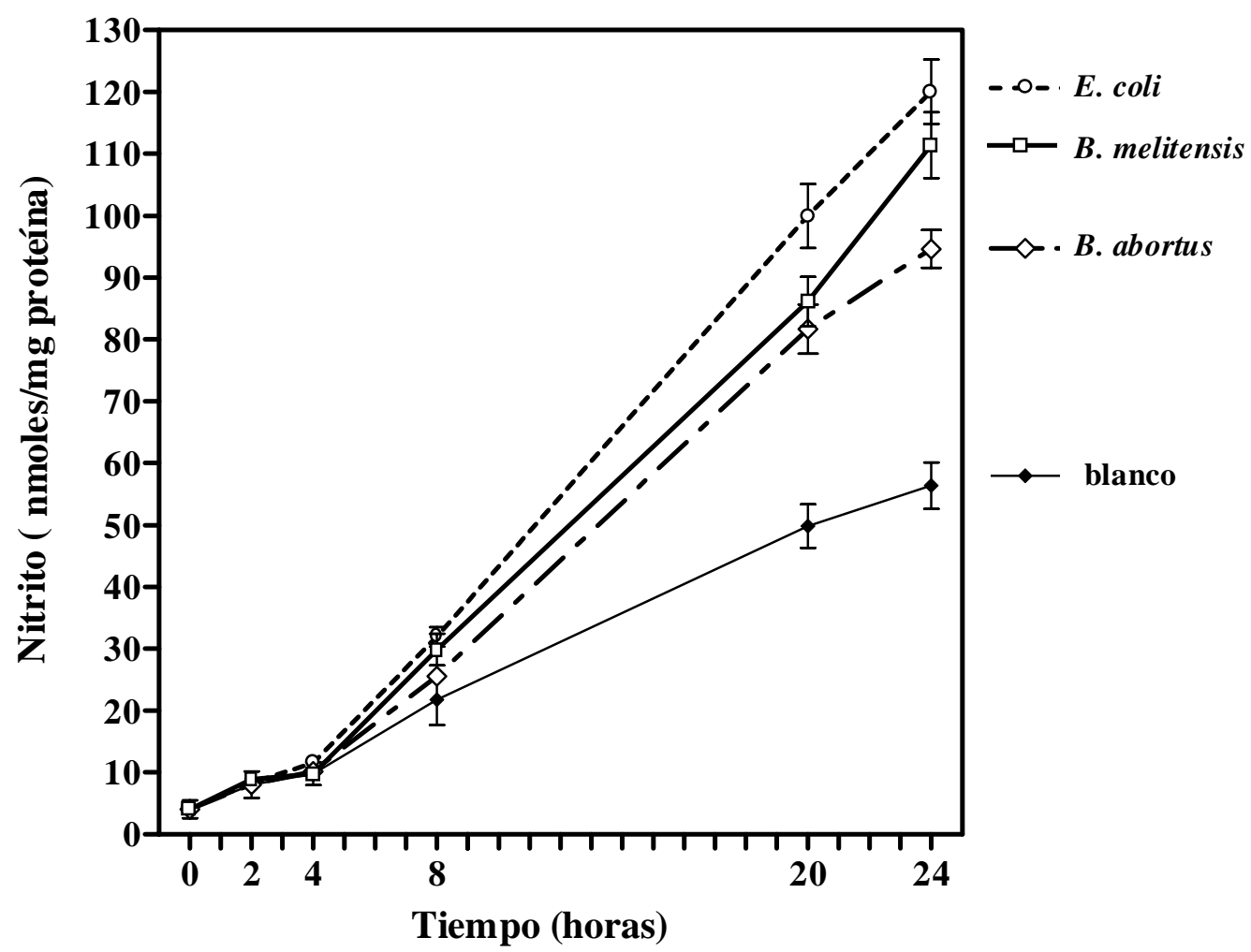

Figura 4.5. CINÉTICA DE INDUCCIÓN DE NO DE LOS LPSs DE E. coli, B. abortus y B. melitensis

Como se observa claramente en la figura 4.5. la inducción de la producción de NO por los tres lipopolisacáridos sigue un patrón temporal, de manera que los macrófagos peritoneales empiezan a producir NO como respuesta a los mismos a partir de las 8 horas de exposición, aumentando de manera lineal con el tiempo hasta las 24 horas. La cinética que presentan los tres lipopolisacáridos es muy similar y las diferencias en el nivel de NO producido están de acuerdo con lo observado en los experimentos de dosisrespuesta para la concentración de $1 \mu \mathrm{g} / \mathrm{ml}$ (ver tabla 4.1).

Para completar este estudio cinético, se determinó en otros experimentos la cantidad de NO producida por estos tres LPSs a las 24, 48 y 72 horas utilizando también la concentración de $1 \mu \mathrm{g} / \mathrm{ml}$. Los resultados que aparecen recogidos en la tabla 4.3. representan la media \pm SEM de 3 experimentos, realizados cada uno de ellos por duplicado, expresando el nivel de NO producido a cada tiempo como porcentaje sobre el blanco. 
Tabla 4.3. Producción de NO a las 24, 48 y 72 horas de exposición a los LPSs de E. coli, B. abortus y B. melitensis expresado como porcentaje sobre el blanco.

\begin{tabular}{||c|c|c|c||}
\hline $\begin{array}{c}\text { Tiempo } \\
\text { (horas) }\end{array}$ & $\begin{array}{c}\text { Escherichia } \\
\text { coli }\end{array}$ & $\begin{array}{c}\text { Brucella } \\
\text { abortus }\end{array}$ & $\begin{array}{c}\text { Brucella } \\
\text { melitensis }\end{array}$ \\
\hline $\mathbf{2 4}$ & $223.7 \pm 3.3$ & $179.6 \pm 17.3$ & $210.9 \pm 2.3$ \\
\hline $\mathbf{4 8}$ & $216.6 \pm 10.4$ & $205.3 \pm 6.9$ & $239.0 \pm 18.2$ \\
\hline $\mathbf{7 2}$ & $216.5 \pm 19.8$ & $226.5 \pm 3.9$ & $224.1 \pm 13.2$ \\
\hline
\end{tabular}

Estos valores aparecen representados en la figura 4.6., no existiendo diferencias significativas ( $p>0.05$ ) en el nivel de NO inducido por los distintos LPSs entre las $24 \mathrm{y}$ 72 horas.



Figura 4.6. Producción de NO por los LPSs de E. coli, B. abortus y B. melitensis expresado como porcentaje sobre el blanco a las 24 (barras vacías), 48 (barras rayadas) y 72 (barras cuadriculadas) horas. 


\subsection{INDUCCIÓN DE LA PRODUCCIÓN DE NO POR LOS LÍPIDOS A DE Escherichia coli, Brucella abortus y Brucella melitensis}

Los lípidos A de E. coli, B. abortus y B. melitensis inducen la producción de óxido nítrico en las células adherentes peritoneales, medida como acumulación de nitritos y expresada como nanomoles/miligramo de proteína. Los resultados tras $24 \mathrm{~h}$ de estimulación con los distintos lípidos A a las diferentes concentraciones utilizadas quedan reflejados en la tabla 4.4 .

Tabla 4.4. Producción de NO por las células adherentes peritoneales estimuladas 24 h con los lípidos A de E. coli, B. abortus y B. melitensis a diferentes concentraciones. Los resultados se expresan como la media \pm SEM de 4 experimentos realizados cada uno por duplicado.

\begin{tabular}{||c|c|c|c||}
\hline $\begin{array}{c}\text { LípA } \\
(\boldsymbol{\mu g} / \mathbf{m l})\end{array}$ & $\begin{array}{c}\text { Escherichia } \\
\text { coli }\end{array}$ & $\begin{array}{c}\text { Brucella } \\
\text { abortus }\end{array}$ & $\begin{array}{c}\text { Brucella } \\
\text { melitensis }\end{array}$ \\
\hline Blanco & $57.2 \pm 3.3$ & $57.2 \pm 3.3$ & $57.2 \pm 3.3$ \\
\hline $\mathbf{0 . 0 0 1}$ & $76.6 \pm 1.7$ & $54.2 \pm 4.4$ & $62.6 \pm 7.8$ \\
\hline $\mathbf{0 . 0 1}$ & $114.2 \pm 5.8$ & $59.9 \pm 3.7$ & $56.9 \pm 8.9$ \\
\hline $\mathbf{0 . 1}$ & $135.0 \pm 3.9$ & $83.0 \pm 6.9$ & $80.7 \pm 8.1$ \\
\hline $\mathbf{1}$ & $134.9 . \pm 2.8$ & $122.4 \pm 7.0$ & $118.6 \pm 8.6$ \\
\hline $\mathbf{1 0}$ & $128.4 \pm 3.4$ & $132.4 \pm 7.1$ & $128.5 \pm 8.8$ \\
\hline
\end{tabular}

Al igual que hicimos con los lipopolisacáridos describiremos cada uno individualmente y luego haremos la comparación entre los tres.

\subsubsection{Lípido A de E. coli}

En la figura 4.7. vemos los niveles de NO inducidos por las distintas concentraciones del lípido A de E. coli tras 24 h de estimulación. Como se aprecia es un potente inductor de NO determinando su producción desde concentraciones muy bajas $(0.001 \mu \mathrm{g} / \mathrm{ml})$ y alcanzando el máximo de inducción a dosis también bajas $(0.1 \mu \mathrm{g} / \mathrm{ml})$. A partir de esta concentración no se produce un aumento en la producción de NO al aumentar la dosis de lípido A. 


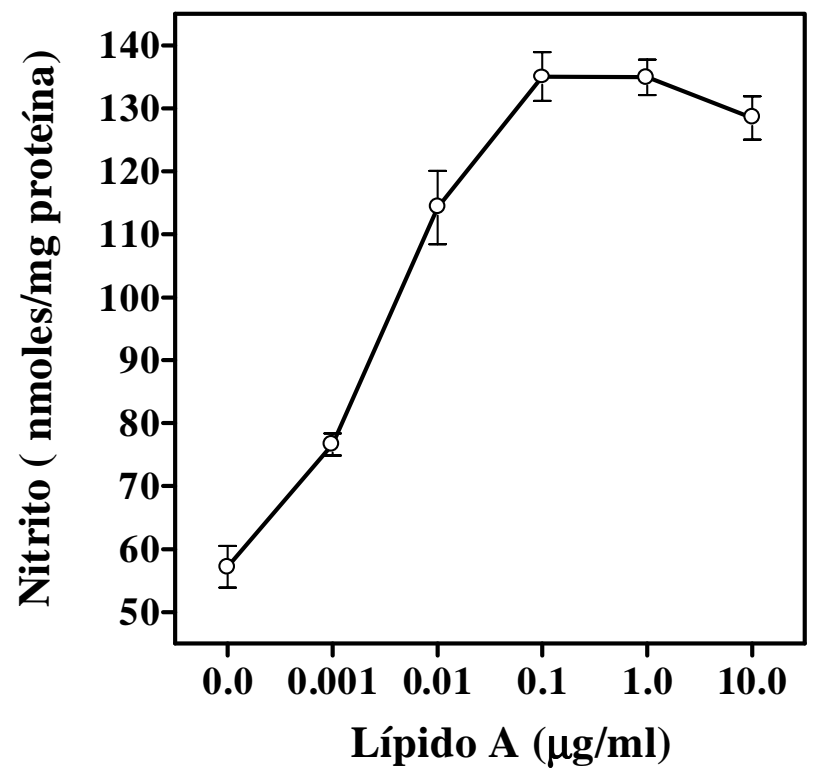

Figura 4.7. CURVA DOSIS-RESPUESTA DEL lípA DE Escherichia coli

\subsubsection{Lípido A de B. abortus}

A diferencia del lípido A de E. coli, el lípido A de B. abortus induce, tras 24 h de incubación, la producción de NO a niveles superiores a las células blanco a partir de la concentración de $0.01 \mu \mathrm{g} / \mathrm{ml}$ incrementándose hasta la concentración de $1 \mu \mathrm{g} / \mathrm{ml}$ a la que alcanza un nivel máximo de inducción similar al inducido por $10 \mu \mathrm{g} / \mathrm{ml}$ (fig.4.8).

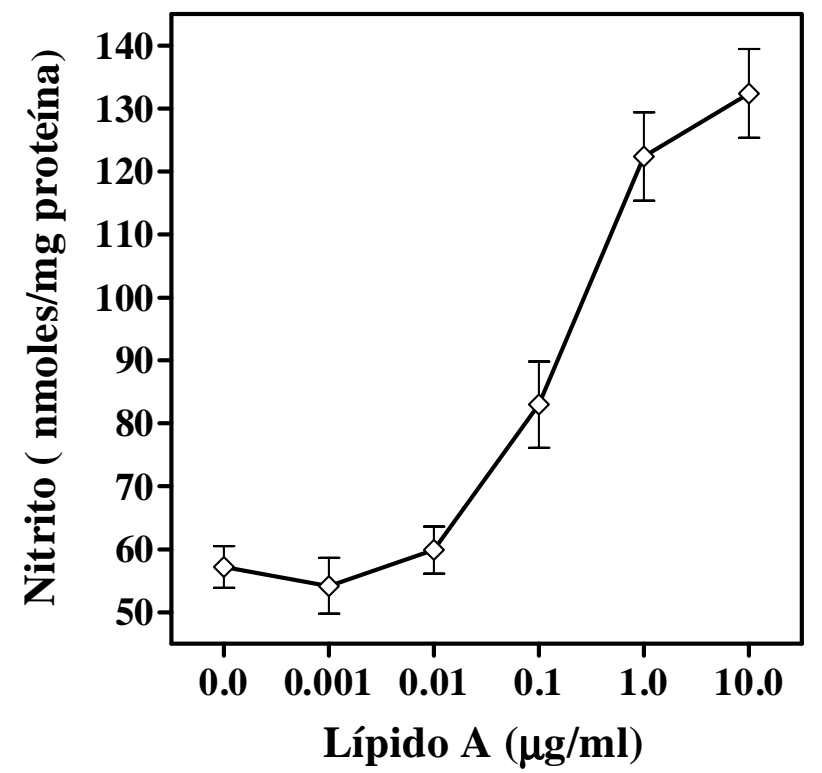

Figura 4.8. CURVA DOSIS-RESPUESTA DEL lípA DE Brucella abortus 


\subsubsection{Lípido A de B. melitensis}

La curva de inducción de NO del lípido A de B. melitensis a las 24 h de estimulación es muy similar a la de $B$. abortus, con la producción de NO a niveles superiores al blanco desde la concentración de $0.01 \mu \mathrm{g} / \mathrm{ml}$ e incrementándose hasta alcanzar un nivel máximo de inducción también a $1 \mu \mathrm{g} / \mathrm{ml}$, no aumentando significativamente a la dosis de $10 \mu \mathrm{g} / \mathrm{ml}$ (fig.4.9).

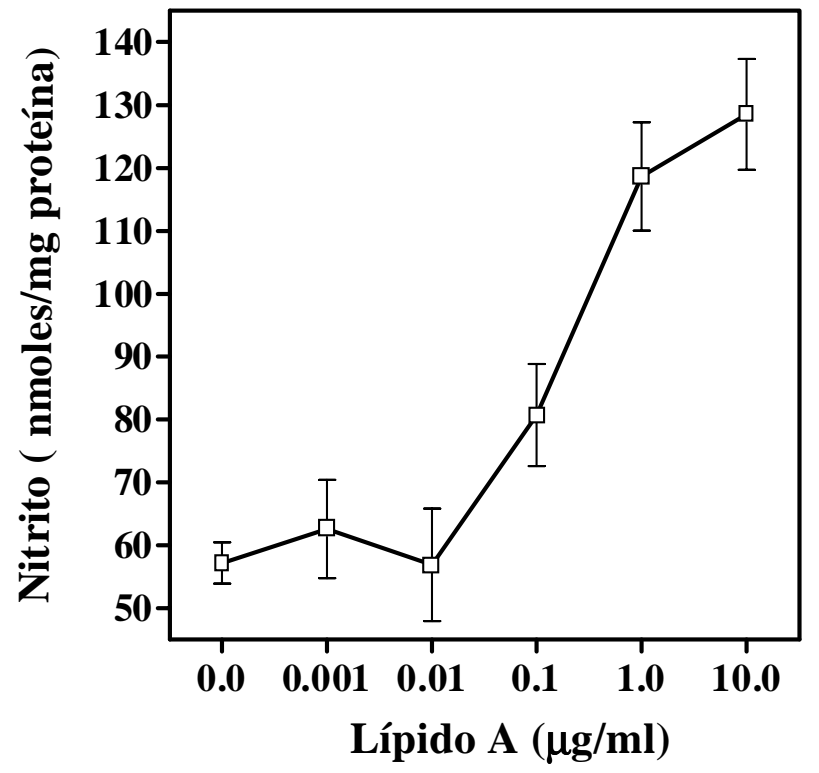

Figura 4.9. CURVA DOSIS-RESPUESTA DEL lípA DE Brucella melitensis

\subsubsection{Comparación del nivel de NO inducido por los LípAs de E. coli, B. abortus y B. melitensis}

En la figura 4.10. representamos el nivel de NO inducido por estos tres lípidos A. Comparando los niveles de NO producidos por los macrófagos peritoneales tras la exposición $24 \mathrm{~h}$ a estos tres lípidos A, observamos que a dosis de $0.01 \mu \mathrm{g} / \mathrm{ml}$ la cantidad de NO inducida por el lípido A de E. coli es significativamente superior a la inducida por los lípidos A de B. abortus y B. melitensis $(\mathrm{p}<0.001)$. De la misma forma a la concentración de $0.1 \mu \mathrm{g} / \mathrm{ml}$ la cantidad de NO inducida por el lípido A de E. coli es significativamente superior a la inducida por los lípidos A de B. abortus y B. melitensis $(\mathrm{p}<0.001)$. No existen diferencias significativas a ninguna concentración entre los lípidos A de B. abortus y B. melitensis. 
El lípido A de E. coli se muestra como un inductor más potente que su LPS, con diferencias significativas a las concentraciones de 0.01 y $0.1 \mu \mathrm{g} / \mathrm{ml}(\mathrm{p}<0.001)$ y a la concentración de $1 \mu \mathrm{g} / \mathrm{ml}(\mathrm{p}<0.01)$.

No existen diferencias en el nivel de NO inducido por el lípido A y el S-LPS de B. melitensis a ninguna concentración ( $\mathrm{p}>0.05)$.

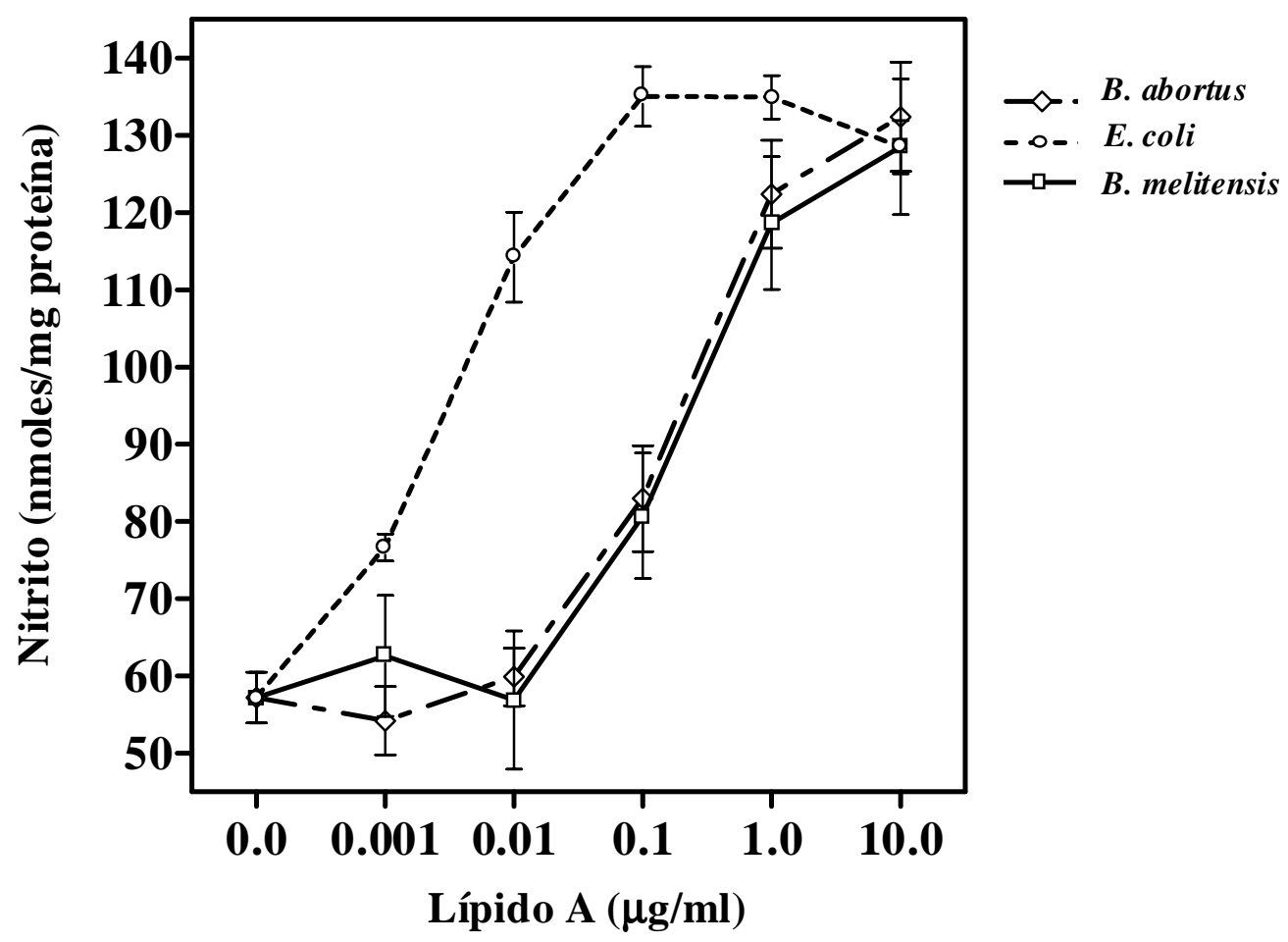

Figura 4.10. INDUCCIÓN DE NO POR LOS lípAs DE E. coli, B. abortus y B. melitensis

\subsubsection{Comparación del nivel de NO inducido por el S-LPS, lípido A y polisacárido $O$ de B. abortus}

En otros experimentos realizados del mismo modo que todos los anteriores se determinó el nivel de NO inducido tras estimulación 24 h con distintas concentraciones del polisacárido $\mathrm{O}$ de $B$. abortus. Para compararlo con el S-LPS y el lípido A, expresaremos los valores obtenidos para el polisacárido $\mathrm{O}$ como porcentaje sobre el blanco, representando la media \pm S.E.M de 3 experimentos realizados en duplicado. En la tabla 4.5. quedan recogidos los resultados, y representados en la figura 4.11. 
Como vemos el polisacárido $\mathrm{O}$ de $B$. abortus sólo induce niveles de NO superiores a los de las células blanco a partir de la concentración de $1 \mu \mathrm{g} / \mathrm{ml}$, produciendo a la concentración máxima de $10 \mu \mathrm{g} / \mathrm{ml}$ un valor sólo del $147.8 \%$ sobre el blanco.

Tabla 4.5. Producción de NO por el S-LPS, lípido A y polisacárido O de B. abortus (\% sobre el blanco)

\begin{tabular}{|c|c|c|c||}
\hline $\boldsymbol{\mu g} / \mathbf{m l}$ & S-LPS & Lípido A & Polisacárido O \\
\hline $\mathbf{0 . 0 0 1}$ & $111.3 \pm 6.8$ & $94.8 \pm 7.7$ & $113.0 \pm 6.4$ \\
\hline $\mathbf{0 . 0 1}$ & $107.1 \pm 6.0$ & $104.7 \pm 6.5$ & $115.9 \pm 7.9$ \\
\hline $\mathbf{0 . 1}$ & $113.1 \pm 8.0$ & $145.1 \pm 12.0$ & $114.4 \pm 9.9$ \\
\hline $\mathbf{1}$ & $170.1 \pm 7.7$ & $214.0 \pm 12.2$ & $123.2 \pm 6.4$ \\
\hline $\mathbf{1 0}$ & $204.9 \pm 4.4$ & $231.4 \pm 12.4$ & $147.8 \pm 5.8$ \\
\hline
\end{tabular}

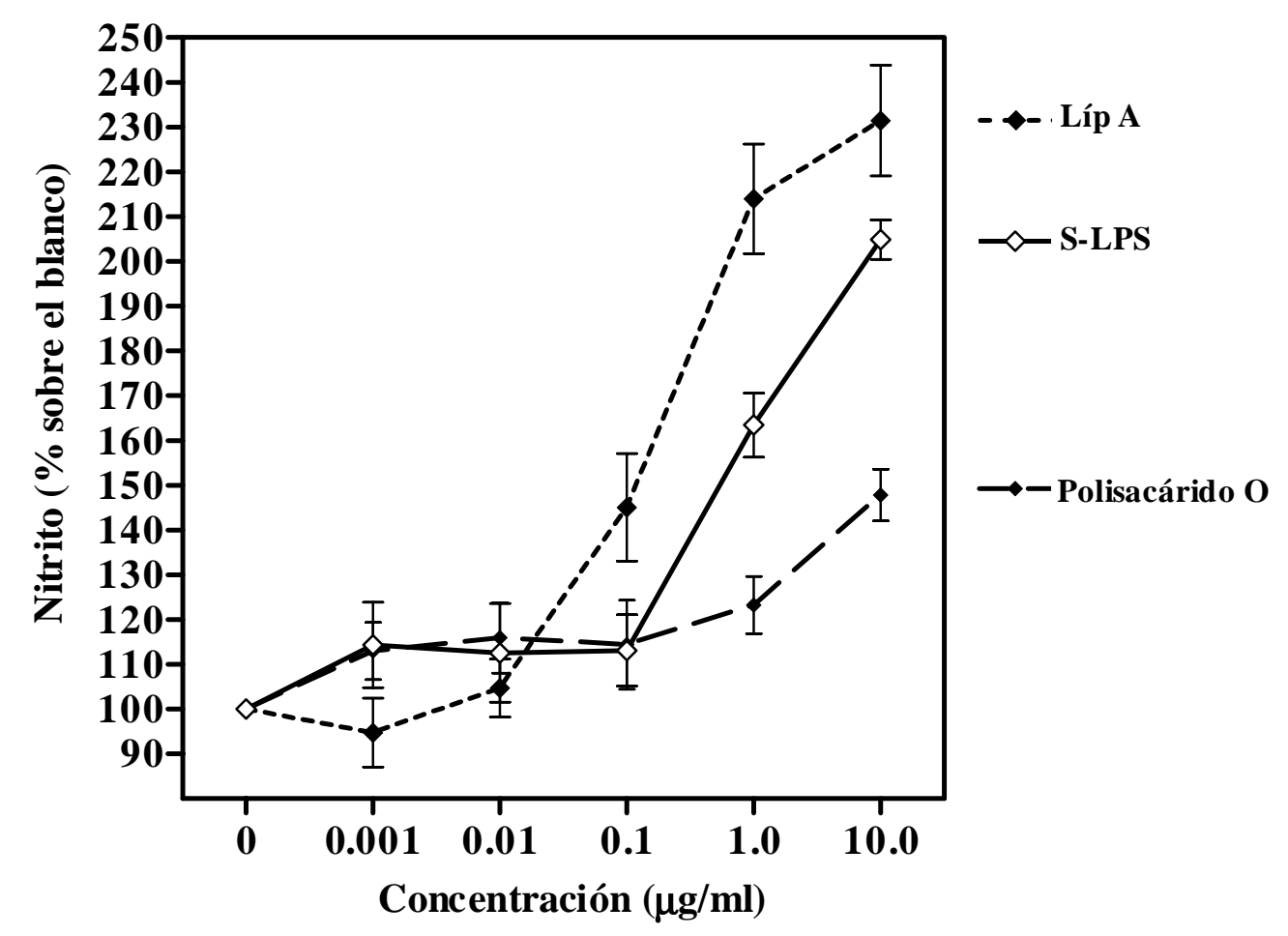

Figura 4.11. INDUCCIÓN DE NO POR EL S-LPS, LípA y POLISACÁRIDO O DE Brucella abortus (\% sobre el blanco) 
A partir de la concentración de $1 \mu \mathrm{g} / \mathrm{ml}$ la cantidad de $\mathrm{NO}$ inducida por el lípido A es superior a la inducida por el lipopolisacárido si bien las diferencias sólo son significativas $(\mathrm{p}<0.01)$ a la concentración de $1 \mu \mathrm{g} / \mathrm{ml}$ de lípido A y LPS.

Al comparar el LPS con el polisacárido $\mathrm{O}$ se observan diferencias significativas a la concentración de $1 \mu \mathrm{g} / \mathrm{ml}$. (p<0.01) y a la dosis de $10 \mu \mathrm{g} / \mathrm{ml}(\mathrm{p}<0.001)$.

\subsection{INHIBICIÓN DE LA PRODUCCIÓN DE NO CON L-NMA}

Para confirmar que la producción de nitrito se producía por la vía de la Larginina, realizamos los siguientes experimentos en los cuales se añadía al medio de cultivo, además de los lipopolisacáridos o lípidos $\mathrm{A}, \mathrm{L}-\mathrm{N}^{\mathrm{G}}$-monometil-L-arginina (L-NMA), un inhibidor específico de la iNOS.

\subsubsection{Inhibición de la producción de NO inducida por los LPSs}

Los macrófagos peritoneales fueron incubados con $1 \mu \mathrm{g} / \mathrm{ml}$ de los LPSs de E. coli, B. abortus y B. melitensis, solos y en presencia del inhibidor (L-NMA $0.5 \mathrm{mM}$ ). Tras 24 horas de incubación se determinó el NO como nitrito expresándose como nanomoles/mg de proteína. En la tabla 4.6. aparecen recogidos los resultados, siendo cada valor la media \pm S.E.M. de tres experimentos realizados en duplicado.

Como se observa claramente en la figura 4.12. la adición del inhibidor bloquea completamente la producción de NO inducida por los LPSs, existiendo diferencias significativas $(\mathrm{p}<0.005)$ para los tres LPSs entre el nivel de NO inducido con y sin L-NMA.

Tabla 4.6. Efecto de L-NMA sobre la producción de NO inducida por los LPS de E. coli, B. abortus y B. melitensis.

\begin{tabular}{|c|c|c|c||}
\hline TRATAMIENTO & E. coli & B. abortus & B. melitensis \\
\hline Blanco & $52.4 \pm 6.7$ & $52.4 \pm 6.7$ & $52.4 \pm 6.7$ \\
\hline LPSs $(1 \mu \mathrm{g} / \mathrm{ml})$ & $101.8 \pm 3.5$ & $87.8 \pm 1.1$ & $98.1 \pm 4.7$ \\
\hline LPSs $(1 \mu \mathrm{g} / \mathrm{ml})+$ L-NMA $(0.5 \mathrm{mM})$ & $43.3 \pm 5.0$ & $30.6 \pm 0.3$ & $50.7 \pm 6.8$ \\
\hline
\end{tabular}




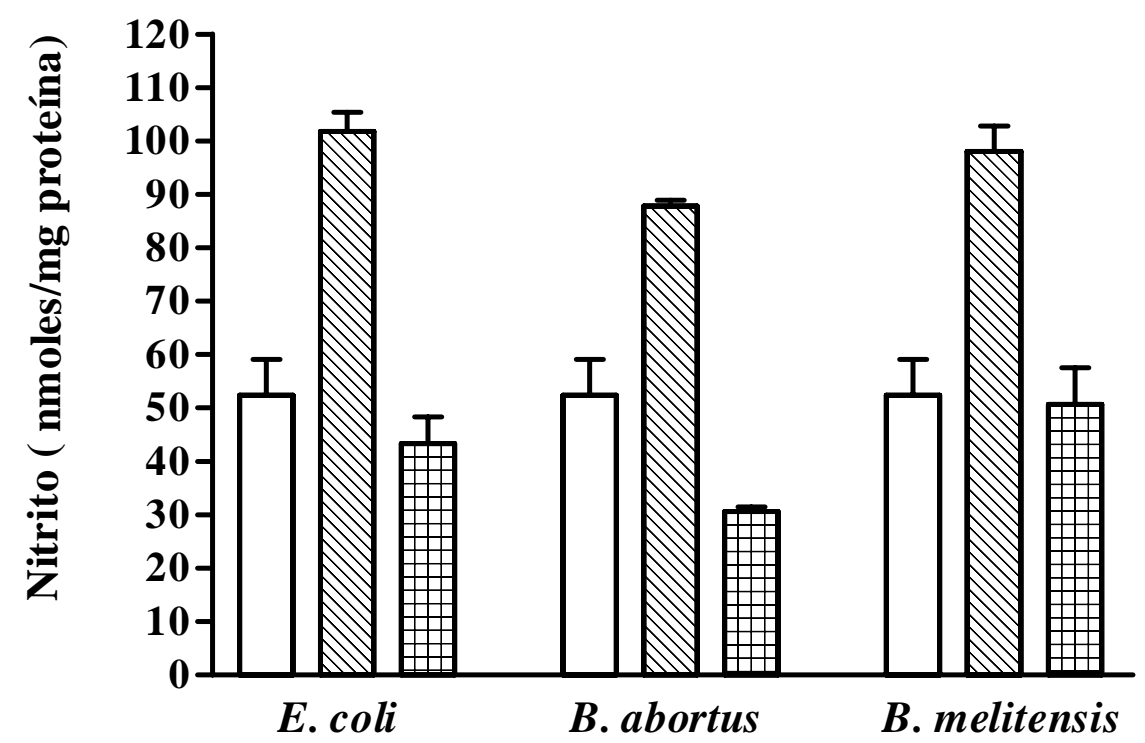

Figura 4.12. Inhibición con L-NMA de la producción de NO por los LPSs de E. coli, B. abortus y B. melitensis. Las barras abiertas representan las células sin tratamiento, las barras rayadas las células tratadas con $1 \mu \mathrm{g} / \mathrm{ml}$ de LPS y las cuadriculadas las células incubadas con LPS más L-NMA (0.5 mM).

\subsubsection{Inhibición de la producción de NO inducida por los lípidos A.}

Al igual que en los experimentos anteriores, los macrófagos peritoneales fueron incubados con $1 \mu \mathrm{g} / \mathrm{ml}$ de los lípidos A de E. coli, B. abortus y B. melitensis, solos y con el inhibidor (L-NMA $0.5 \mathrm{mM}$ ). Tras 24 horas de incubación se determinó el NO como nitrito expresándose como nanomoles/mg de proteína. En la tabla 4.7. aparecen recogidos los resultados, siendo cada valor la media \pm S.E.M. de tres experimentos realizados por duplicado.

Al igual que se observa con los LPSs, la adición del inhibidor bloquea completamente la producción de NO inducida por los distintos lípidos A (figura 4.13.), existiendo diferencias significativas $(\mathrm{p}<0.005)$ para los tres lípidos A entre el nivel de NO inducido con y sin L-NMA. 
Tabla 4.7. Efecto de L-NMA sobre la producción de NO inducida por los lípAs de $E$. coli, B. abortus y B. melitensis.

\begin{tabular}{|c|c|c|c||}
\hline TRATAMIENTO & E. coli & B. abortus & B. melitensis \\
\hline Blanco & $66.7 \pm 8.4$ & $66.7 \pm 8.4$ & $66.7 \pm 8.4$ \\
\hline LípA $(1 \mu \mathrm{g} / \mathrm{ml})$ & $111.8 \pm 1.1$ & $116.7 \pm 2.2$ & $118.2 \pm 6.6$ \\
\hline LípA $(1 \mu \mathrm{g} / \mathrm{ml})+$ L-NMA $(0.5 \mathrm{mM})$ & $61.8 \pm 9.2$ & $56.4 \pm 7.3$ & $53.4 \pm 10.0$ \\
\hline
\end{tabular}

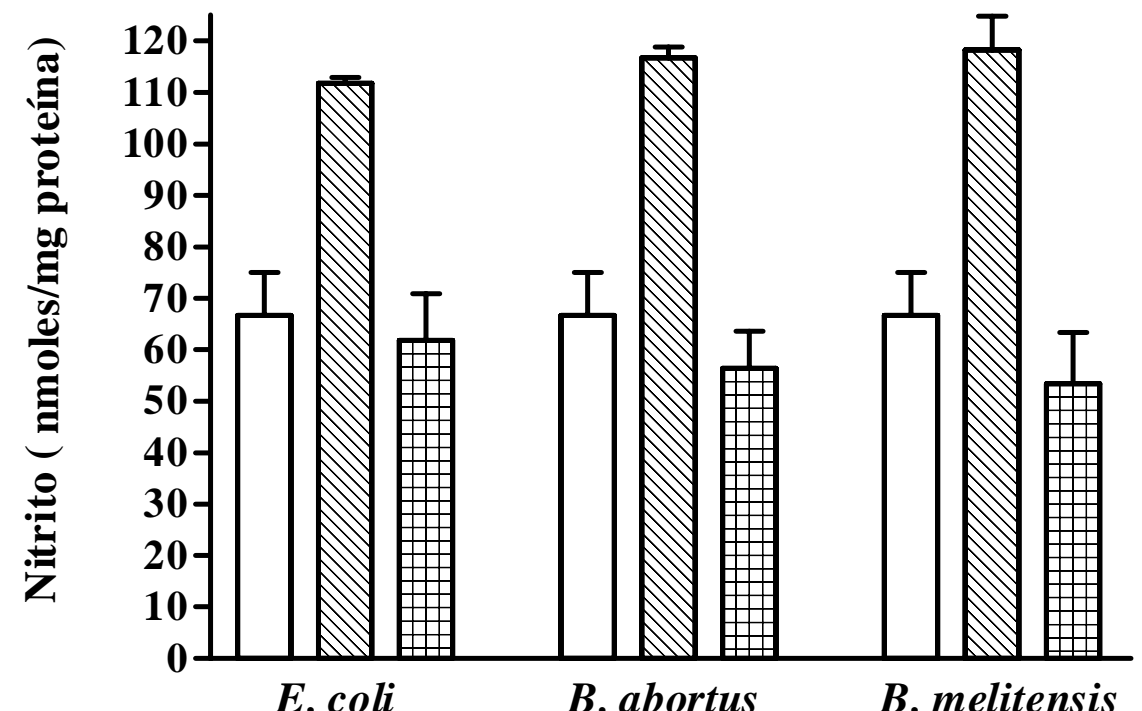

Figura 4.13. Inhibición con L-NMA de la producción de NO inducida por los lípAs de $\boldsymbol{E}$. coli, B. abortus, B. melitensis. Las barras abiertas representan las células sin tratamiento, las barras rayadas las células tratadas con $1 \mu \mathrm{g} / \mathrm{ml}$ de lípA y las cuadriculadas las células incubadas con lípA más L-NMA (0.5 mM).

\subsection{INDUCCIÓN DE LA EXPRESIÓN DEL ARNm DE iNOS}

Los experimentos anteriores sugerían que la enzima implicada en la producción de NO por los macrófagos peritoneales tras la incubación con los lipopolisacáridos era la isoforma inducible de la sintasa de NO. Sin embargo, una comprobación concluyente de este hecho requería demostrar la presencia del ARN mensajero de la iNOS y así realizamos una serie de experimentos utilizando la técnica de Northern blot. 


\subsubsection{Inducción del ARNm de la iNOS por los lipopolisacáridos de E. coli, B. abortus y B. melitensis}

Para llevar a cabo este experimento los macrófagos peritoneales fueron incubados durante 24 horas con $1 \mu \mathrm{g} / \mathrm{ml}$ de los lipopolisacáridos, dosis que como hemos visto en sus curvas dosis respuesta, inducía la producción de NO a niveles significativamente superiores a los producidos por las células blanco. Tras la incubación se extrajo el ARN y se realizó el Northern blot como se indica en material y métodos. En la figura 4.14. podemos observar como los tres lipopolisacáridos inducen la expresión del ARNm de la iNOS a un nivel superior al inducido por las células sin ningún tratamiento. La menor inducción que se observa en el S-LPS de B. abortus está en concordancia con la cantidad de NO inducida por este lipopolisacárido a la concentración de $1 \mu \mathrm{g} / \mathrm{ml}(91.9$ nmoles/mg proteína) que es menor a los otros dos (108.7 para E. coli y 100.3 para B. melitensis)(ver tabla 4.1 y fig.4.4.)

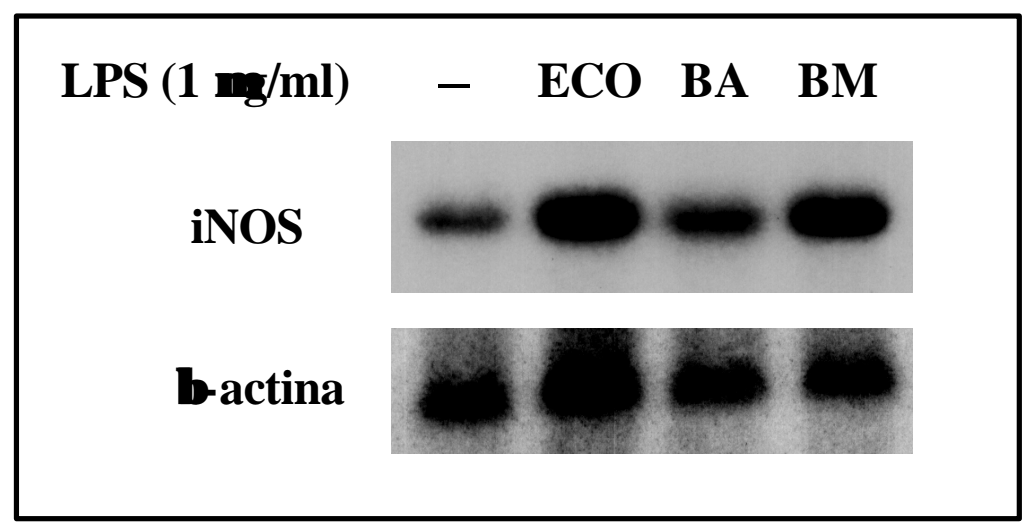

Figura 4.14. Inducción del ARNm de la iNOS por los lipopolisacáridos de $E$. coli, B. abortus y B. melitensis. Se extrajo el ARN de macrófagos no tratados $(-)$ y tratados con $1 \mu \mathrm{g} / \mathrm{ml}$ de LPS de E. coli (ECO), S-LPS de B. abortus (BA) y B. melitensis (BM) y se hibridó con sondas específicas de iNOS y de $\beta$-actina.

\subsubsection{Patrón temporal de la inducción del ARNm de la iNOS}

Como ya vimos en las curvas cinéticas, la producción de NO por los LPSs de E. coli, B. abortus y B. melitensis empieza a presentar niveles superiores a los de las células blanco a partir de las 8 horas de incubación con $1 \mu \mathrm{g} / \mathrm{ml}$ de los mismos (ver tabla 4.2 y figura 4.5.). Esto sugería que participaba la isoenzima inducible de la NOS, que 
requeriría un tiempo para la expresión de su ARNm, así como para su síntesis. En los siguientes experimentos vamos a ver la expresión del ARNm de la iNOS a distintos tiempos de estimulación con los tres LPSs.

\subsubsection{LPS de $E$. coli}

Los macrófagos peritoneales se incubaron con $1 \mu \mathrm{g} / \mathrm{ml}$ de LPS de E. coli, extrayéndose el ARN a los diferentes tiempos indicados en la figura 4.15. Como se ve claramente, el LPS de E. coli induce la expresión del ARNm de iNOS de forma dependiente con el tiempo, incrementándose hasta ser máxima a las 8 horas de estimulación y manteniéndose elevada por encima de la expresión de las células control como se demuestra al tiempo de 24 horas. Este patrón de expresión coincide con el de liberación de NO e indica que es necesaria la inducción de la enzima para que esta pueda producir NO medible como nitrito en la reacción de Griess.

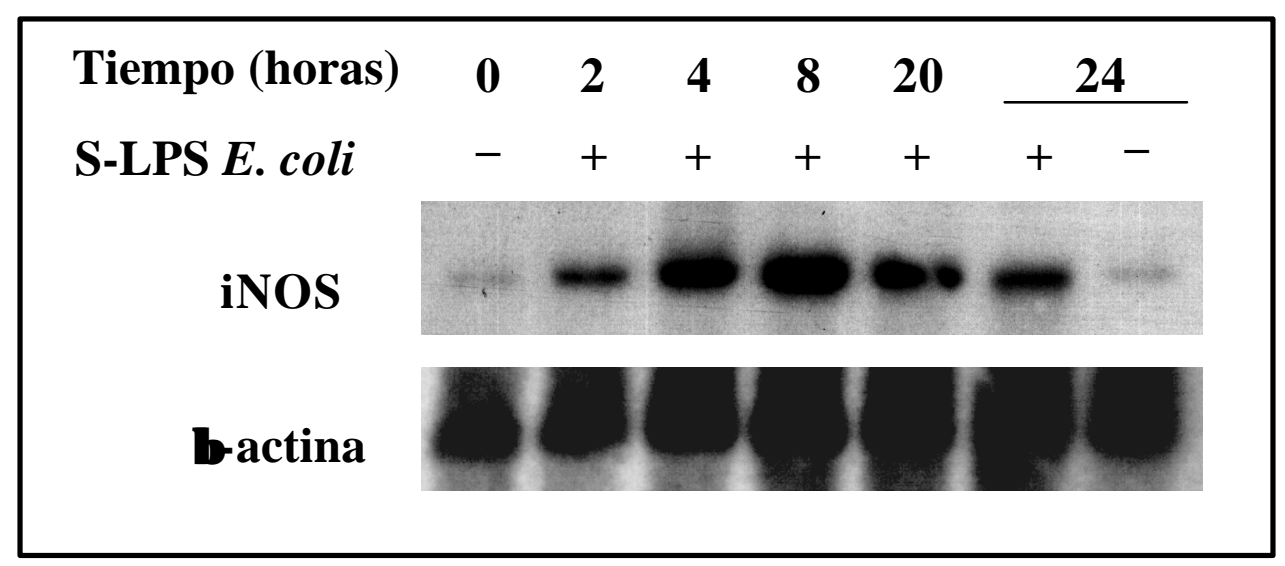

Figura 4.15. Curso temporal de la inducción de ARNm de iNOS por el LPS de $\boldsymbol{E}$. coli. A los distintos tiempos indicados en la figura se extrajo el ARN de las células incubadas $(+)$ o no $(-)$ con $1 \mu \mathrm{g} / \mathrm{ml}$ de LPS de E. coli. El ARN se hibridó con sondas específicas de iNOS y de $\beta$-actina.

\subsubsection{S-LPS de B. abortus}

Del mismo modo que en el experimento anterior, los macrófagos peritoneales fueron incubados con $1 \mu \mathrm{g} / \mathrm{ml}$ del SLPS de $B$. abortus, extrayéndose el ARN a los diferentes tiempos indicados en la figura 4.16. Se observa como el S-LPS de B. abortus induce la expresión del ARNm de la iNOS de forma dependiente del tiempo, siendo máxima la expresión a las 4 horas de estimulación, manteniéndose por encima del nivel de expresión de las células control como se comprueba a las 24 horas. De nuevo este 
patrón coincide con el de la liberación de NO, demostrándonos que el S-LPS de B. abortus induce la producción de NO tras la inducción de la expresión de la enzima iNOS.

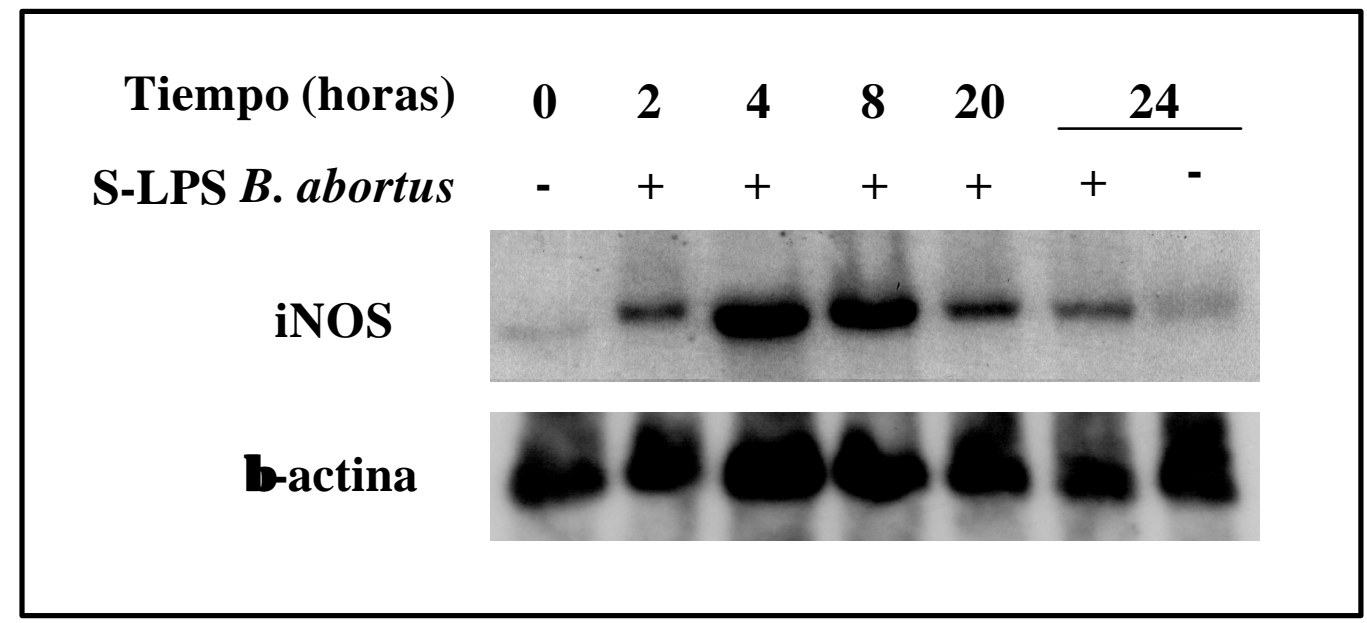

Figura 4.16. Curso temporal de la inducción de ARNm de iNOS por el S-LPS de B. abortus. A los distintos tiempos indicados en la figura se extrajo el ARN de las células incubadas $(+)$ o no $(-)$ con $1 \mu \mathrm{g} / \mathrm{ml}$ del S-LPS de B. abortus. El ARN se hibridó con sondas específicas de iNOS y de $\beta$-actina.

\subsubsection{S-LPS de B. melitensis.}

Se realizó el mismo experimento anterior pero con $1 \mu \mathrm{g} / \mathrm{ml}$ de S-LPS de B. melitensis. Con el ARN extraído a los diferentes tiempos se realizó un Northern blot, que como vemos en la figura 4.17. nos permite demostrar como la inducción del ARNm de la iNOS por el de S-LPS de B. melitensis sigue también un patrón temporal, presentando niveles máximos de inducción entre las 4 y las 20 horas de estimulación, siendo superior al nivel de expresión inducido por las células control como se observa a las 24 horas. Al igual que los otros LPSs este patrón coincide con el de liberación de NO. 


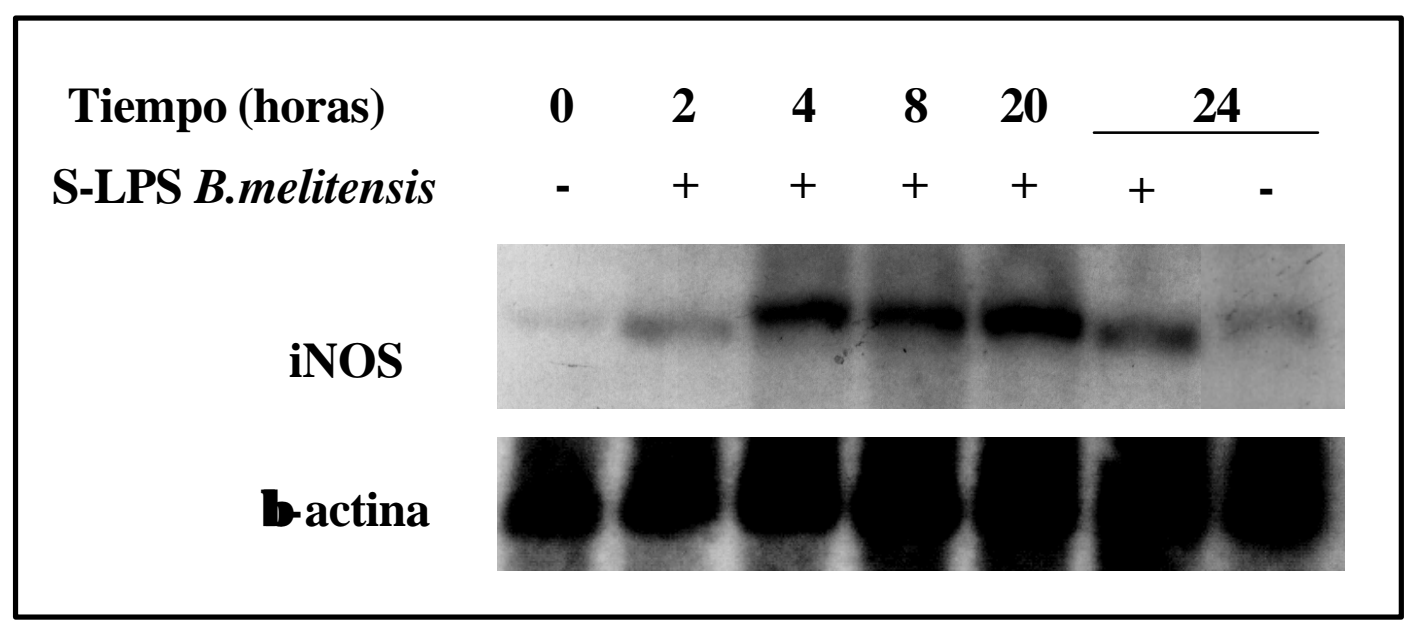

Figura 4.17. Curso temporal de la inducción de ARNm de iNOS por el S-LPS de B. melitensis. A los distintos tiempos indicados en la figura se extrajo el ARN de las células incubadas $(+)$ o no $(-)$ con $1 \mu \mathrm{g} / \mathrm{ml}$ del S-LPS de B. melitensis. El ARN se hibridó con sondas específicas de iNOS y de $\beta$-actina.

\subsubsection{Inducción del ARNm de la iNOS por los lípAs de E. coli, B. abortus y B. melitensis}

Los lípidos A también inducen la producción de NO por los macrófagos peritoneales, por un mecanismo bloqueable en presencia de L-NMA. Estos datos sugieren la participación de la iNOS, y para demostrarlo concluyentemente estudiamos si se producía inducción de la expresión $\mathrm{ARNm}$ de la iNOS por los lípidos A. Los macrófagos peritoneales fueron incubados con los 3 lípidos A a la concentración de $1 \mu \mathrm{g} / \mathrm{ml}$ a la cual, como vimos en las curvas dosis respuesta, inducen un nivel máximo de producción de NO. En el mismo experimento volvimos a incluir los respectivos LPSs también a la concentración de $1 \mu \mathrm{g} / \mathrm{ml}$. Tras 24 horas de incubación se extrajo el ARN y se hibridó con sondas específicas para iNOS y $\beta$-actina. El resultado se observa en la figura 4.18. y vemos como los tres lípidos A inducen la expresión de ARNm de la iNOS a un nivel superior al expresado por las células no estimuladas. El nivel de ARNm inducido por los tres lípidos A, es ligeramente superior al inducido por los respectivos lipopolisacáridos, lo cual está de acuerdo con lo observado en los niveles de NO, que son, expresados en \% sobre el blanco: para el LPS de E. coli, $201.3 \%$, frente al lípA, $235.8 \%$, (p<0.005); para el S-LPS de B. abortus, 163.4\%, frente al lípido A, $214.0 \%(\mathrm{p}<0.05)$ y para el S-LPS de B. melitensis $185.7 \%$ frente al lípido A $207.4 \%$ $(\mathrm{p}>0.05)$. 




Figura 4.18. Inducción del ARNm de la iNOS por los lípidos A y lipopolisacáridos de E. coli, B. abortus y B. melitensis. Se extrajo el ARN de macrófagos no tratados ( - ) y tratados con $1 \mu \mathrm{g} / \mathrm{ml}$ de lipopolisacárido (LPS) o de lípido A (lípA) de E. coli (ECO), B. abortus (BA) y B. melitensis (BM) y se hibridó con sondas específicas de iNOS y de $\beta$-actina.

\subsection{INDUCCIÓN DE LA EXPRESIÓN DE LA PROTEÍNA DE iNOS}

Como hemos descrito, la producción de NO por los LPSs de E. coli, B. abortus y B. melitensis se acompaña de la expresión del ARNm de la iNOS y por tanto debe acompañarse también de la inducción de la expresión de la proteína. Para demostrarlo los macrófagos peritoneales se incubaron 24 horas con $10 \mu \mathrm{g} / \mathrm{ml}$ de los 3 LPSs, tras lo cual se extrajo la proteína y se realizó un Western blot que se muestra en la figura 4.19. Se observa que los tres LPSs son capaces de inducir la proteína de iNOS.

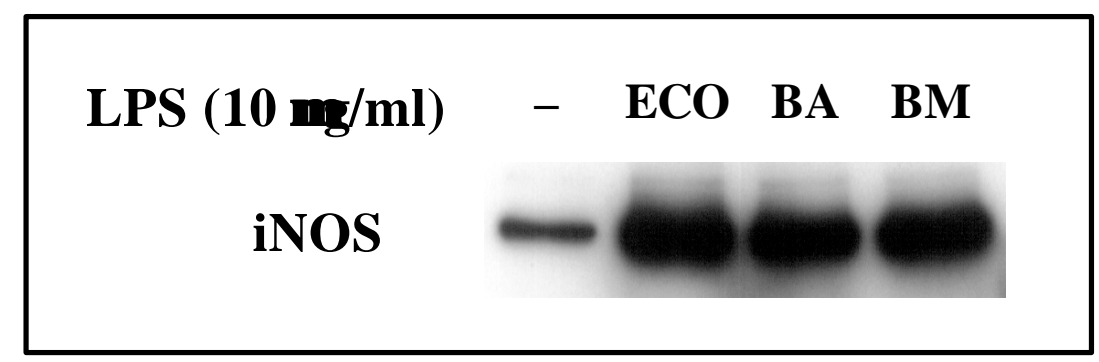

Figura 4.19. Inducción de la proteína de la iNOS por los lipopolisacáridos de E. coli, B. abortus y B. melitensis. Se extrajo la proteína de macrófagos no tratados ( - ) y tratados con $10 \mu \mathrm{g} / \mathrm{ml}$ de LPS de E. coli (ECO), S-LPS de B. abortus (BA) y S-LPS de $B$. melitensis $(\mathbf{B M})$ realizándose la inmunodetección con anticuerpo específico de la iNOS. 


\subsection{OTROS LIPOPOLISACÁRIDOS RELACIONADOS}

\subsubsection{Inducción de la producción de NO}

Los lipopolisacáridos de Escherichia hermannii, Pseudomonas maltophilia, Yersinia enterocolitica y Ochrobactrum anthropi, que presentan reacciones serológicas cruzadas con el lipopolisacárido de Brucella, inducen la producción de óxido nítrico en las células adherentes peritoneales, medida como acumulación de nitrito y expresada como nanomoles/miligramo de proteína. Los resultados para los distintos lipopolisacáridos tras $24 \mathrm{~h}$ de estimulación, a las diferentes concentraciones utilizadas quedan reflejados en la tabla 4.8.

Tabla 4.8. Producción de NO por las células adherentes peritoneales estimuladas $24 \mathrm{~h}$ con los LPS de Escherichia hermannii, Pseudomonas maltophilia, Yersinia enterocolitica y Ochrobactrum anthropi a diferentes concentraciones. Los resultados se expresan como nanomoles/mg proteína. Cada valor representa la media \pm SEM de 5 experimentos realizados cada uno por duplicado.

\begin{tabular}{||c|c|c|c|c||}
\hline $\begin{array}{c}\text { LPS } \\
\mathbf{M g} / \mathbf{m l}\end{array}$ & $\begin{array}{c}\text { Escherichia } \\
\text { hermannii }\end{array}$ & $\begin{array}{c}\text { Yersinia } \\
\text { enterocolitica }\end{array}$ & $\begin{array}{c}\text { Xanthomonas } \\
\text { maltophilia }\end{array}$ & $\begin{array}{c}\text { Ochrobactrum } \\
\text { anthropi }\end{array}$ \\
\hline Blanco & $59.9 \pm 4.4$ & $63.0 \pm 5.0$ & $65.1 \pm 4.4$ & $55.4 \pm 4.0$ \\
\hline $\mathbf{0 . 0 0 1}$ & $70.1 \pm 4.1$ & $71.9 \pm 6.0$ & $60.3 \pm 1.1$ & $54.0 \pm 3.5$ \\
\hline $\mathbf{0 . 0 1}$ & $72.0 \pm 5.3$ & $105.2 \pm 8.9$ & $70.0 \pm 4.8$ & $57.0 \pm 1.9$ \\
\hline $\mathbf{0 . 1}$ & $92.9 \pm 1.0$ & $116.9 \pm 9.2$ & $90.2 \pm 6.1$ & $64.1 \pm 4.1$ \\
\hline $\mathbf{1}$ & $124.4 \pm 2.7$ & $109.5 \pm 4.1$ & $125.2 \pm 5.1$ & $97.5 \pm 6.1$ \\
\hline $\mathbf{1 0}$ & $125.5 \pm 1.3$ & $104.8 \pm 8.1$ & $120.2 \pm 3.7$ & $125.7 \pm 3.1$ \\
\hline
\end{tabular}

\subsubsection{LPS de Escherichia hermannii}

El LPS de E. hermannii es capaz de inducir la producción de NO por las células adherentes peritoneales incubadas $24 \mathrm{~h}$ con el mismo como apreciamos en la figura 4.20. Concentraciones de LPS inferiores a $0.01 \mu \mathrm{g} / \mathrm{ml}$ no inducen un nivel de NO superior a las células control, incrementándose a partir de dicha concentración hasta alcanzar el máximo de inducción a la dosis de $1 \mu \mathrm{g} / \mathrm{ml}$. 


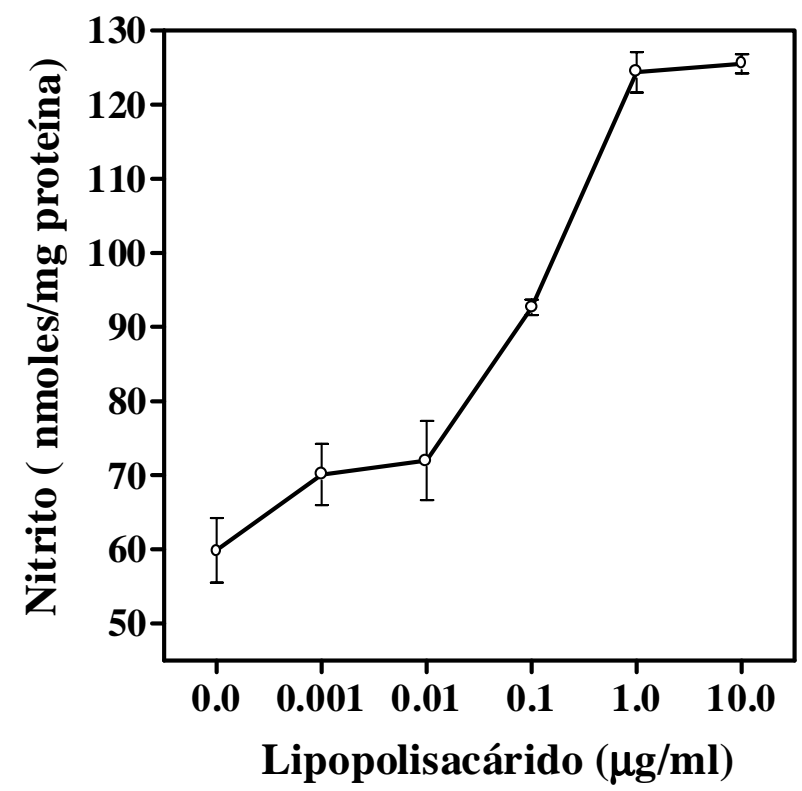

FIGURA 4.20. CURVA DOSIS RESPUESTA del LPS de Escherichia hermannii

\subsubsection{LPS de Yersinia enterocolitica 0:9}

Aunque también induce la producción de NO, el perfil de su curva dosis-respuesta tras 24 h de estimulación es diferente al de los otros LPS ensayados, como se aprecia en la figura 4.21., pues alcanza niveles superiores a las células control a dosis más bajas que los otros LPSs. Así a la dosis de $0.01 \mu \mathrm{g} / \mathrm{ml}$, ya se alcanza el nivel máximo de inducción de NO, a partir de la cual no se produce un aumento mayor en su producción.

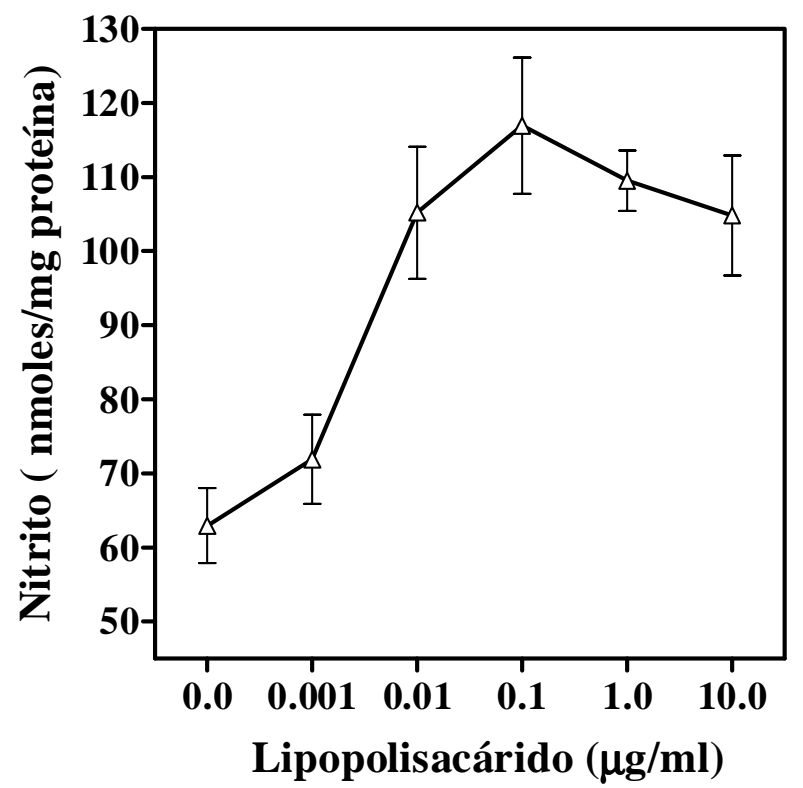

FIGURA 4.21. CURVA DOSIS RESPUESTA del LPS de Yersinia enterocolitica 


\subsubsection{LPS de Pseudomonas (Xanthomonas) maltophilia.}

Presenta una curva dosis respuesta a las 24 h de incubación parecida a las de los otros lipopolisacáridos (figura 4.22.), con niveles similares a las células blanco hasta la concentración de $0.01 \mu \mathrm{g} / \mathrm{ml}$, para incrementarse con la dosis hasta alcanzar su máximo nivel de inducción a la dosis de $1 \mu \mathrm{g} / \mathrm{ml}$, no aumentando la cantidad de $\mathrm{NO}$ a dosis de LPS superiores.

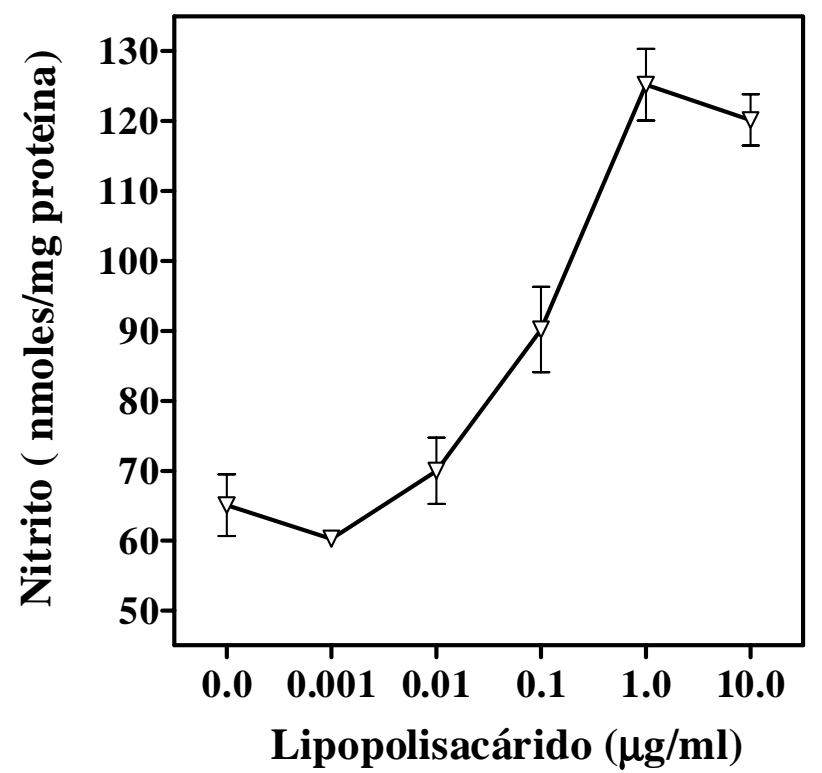

FIGURA 4.22. CURVA DOSIS RESPUESTA del LPS de Pseudomonas maltophilia

\subsubsection{LPS de Ochrobactrum anthropi}

Como vemos en la figura 4.23., el LPS de O. antrhopi sólo presenta un nivel de producción de NO apreciable con respecto a las células control a la concentración de 1.0 $\mu \mathrm{g} / \mathrm{ml}$ (al igual que ocurría con el S-LPS de B. abortus), alcanzando a la concentración de $10 \mu \mathrm{g} / \mathrm{ml}$ un nivel máximo de producción de NO comparable al nivel máximo producido por el resto de los lipopolisacáridos. 




FIGURA 4.23. CURVA DOSIS RESPUESTA del LPS de Ochrobactrum anthropi

\subsubsection{Inducción del ARNm de la iNOS por los lipopolisacáridos de E. hermannii, Y. enterocolitica, $P$. maltophilia y $O$. anthropi.}

Estos lipopolisacáridos, que producen reacciones serológicas cruzadas con los lipopolisacáridos de Brucella, son capaces también de inducir la producción de NO por los macrófagos peritoneales. Por lo tanto deben inducir también la expresión del ARNm de la iNOS. Para demostrarlo realizamos el siguiente experimento en el que al igual que los anteriores tras la estimulación de los macrófagos durante 24 horas con $1 \mu \mathrm{g} / \mathrm{ml} \mathrm{de}$ los distintos LPSs se extrajo el ARN y se realizó un Northern blot. Como se ve en la figura 4.24. todos los LPSs indujeron la expresión de ARNm de la iNOS. Las diferencias en la expresión de ARNm concuerdan con el diferente nivel de NO producido por los distintos LPSs a la concentración de $1 \mu \mathrm{g} / \mathrm{ml}$ que era, expresado como \% sobre el blanco: E. coli $(201.3 \%)$; B. abortus (170.1\%), B. melitensis $(185.7 \%)$, E. hermannii (207.6 \%), Y. enterocolitica (173.8\%), P. maltophilia (192.3\%) y O. anthropi (176.0\%). 


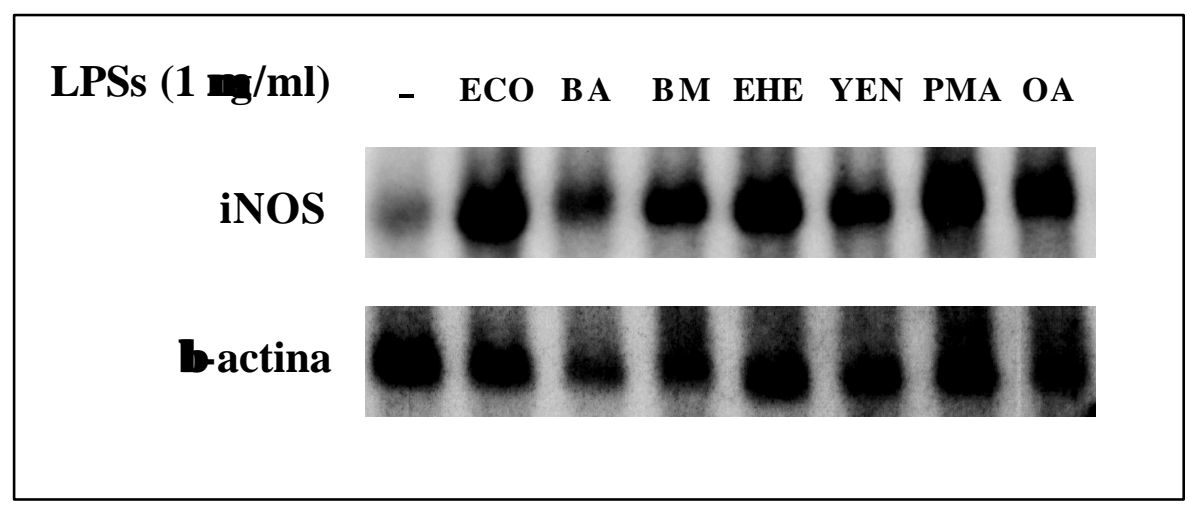

Figura 4.24. Inducción del ARNm de la iNOS por los lipopolisacáridos de E. hermannii, $Y$. enterocolitica, Pseudomonas maltophilia y Ochrobactrum anthropi. Se extrajo el ARN de macrófagos no tratados (-) y tratados con $1 \mu \mathrm{g} / \mathrm{ml}$ de los lipopolisacáridos (LPSs) de E. coli (ECO), B. abortus (BA), B. melitensis (BM), E. hermannii (EHE), Y. enterocolitica (YEN), P. maltophilia (PMA) y O. anthropi (OA) y se hibridó con sondas específicas de iNOS y de $\beta$-actina. 
V. DISCUSIÓN 


\subsection{INDUCCIÓN DE LA PRODUCCIÓN DE NO POR LOS S-LPSs y lípAs DE B. abortus y B. melitensis.}

El hecho de que el óxido nítrico sea una molécula con propiedades antimicrobianas que constituye uno de los sistemas bactericidas de las células fagocíticas, obliga a considerar su mecanismo de producción en respuesta al LPS de bacterias gram negativas desde una doble vertiente. Por un lado, como uno de los desencadenantes de la producción de efectos adversos para el huesped durante la infección por bacterias gram negativas. Por otra parte, puesto que las brucelas sobreviven y se multiplican en el interior de las células fagocíticas se plantean numerosos interrogantes en cuanto a la posible inducción de la producción de óxido nítrico por los productos derivados de Brucella y la resistencia a su toxicidad por parte de las bacterias.

\subsubsection{INDUCCIÓN POR LOS S-LPSs}

En el presente estudio hemos mostrado que los S-LPSs de B. abortus y B. melitensis inducen la producción de NO por los macrófagos peritoneales de rata de forma dependiente del tiempo y de la dosis. Esta producción es comparable a la producida por el lipopolisacárido de E. coli, que es el compuesto de referencia utilizado para inducir la producción de NO.

En el sistema de células adherentes del peritoneo de rata, el LPS de E. coli indujo la producción de NO desde la concentración de $0.01 \mu \mathrm{g} / \mathrm{ml}$. Sin embargo, los SLPSs de B. abortus y B. melitensis, aunque a la concentración de $10 \mu \mathrm{g} / \mathrm{ml}$ inducen una producción de NO similar a la producida por el LPS de E. coli, se comportan como inductores menos potentes a dosis bajas, puesto que sólo inducen respuesta a concentraciones superiores a $0.1 \mu \mathrm{g} / \mathrm{ml}$, siendo necesaria una concentración de $1 \mu \mathrm{g} / \mathrm{ml}$ para alcanzar niveles de NO similares a los inducidos por LPS de E. coli a la concentración de $0.1 \mu \mathrm{g} / \mathrm{ml}$.

La inducción de NO por el S-LPS de Brucella no se ha medido con anterioridad de forma directa. Distintos autores han sugerido una relación entre el NO y las brucelas en experimentos realizados con las bacterias, pero no la han demostrado de forma convincente. Así Jiang et al. ${ }^{(272)}$ eliminaban en su estudio las brucelas extracelulares muertas, preocupados por minimizar el posible efecto en la activación de los macrófagos que pudiera tener el LPS. Estos autores no descartan la contribución del 
LPS a la activación de los macrófagos de su sistema, pero la limitación de su abordaje experimental impide analizar d papel del LPS. Por otra parte Zhan et al. ${ }^{(273)}$ encuentran que la depleción de IL-12 determina una producción reducida de NO por parte de las células esplénicas de ratones infectados con Brucella, y postulan que el lipopolisacárido intacto de Brucella estimula a los macrófagos a producir IL-12 y otras citocinas coestimuladoras in vitro, pero no se refieren a un posible papel del LPS en la inducción de NO. Gross et al. ${ }^{(113)}$ sugieren que la menor reactividad del LPS de Brucella respecto al de E. coli explica las discrepancias en la capacidad de ambas bacterias para inducir liberación de NO. Nuestros resultados estarían de acuerdo en cuanto a la menor efectividad del LPS de Brucella, pero muestran, sin embargo, que las dosis altas ejercen un efecto comparable al del LPS de E. coli.

\subsubsection{INDUCCIÓN POR LOS LÍPIDOS A}

El lípido A es la parte activa de la molécula de LPS, implicada en muchas de sus acciones biológicas. Así el lípido A es el único componente del LPS de Brucella que interviene en la inducción de la explosión oxidativa, otro mecanismo bactericida de las células fagocíticas, en las que se comporta como un inductor más potente que los correspondientes lipopolisacáridos $^{(5)}$. Nuestros resultados muestran que los lípidos A de E. coli, B. abortus y B. melitensis también inducen la producción de NO por los macrófagos peritoneales de rata de manera dosis dependiente.

De la misma forma que en los experimentos con los lipopolisacáridos, el lípido A de E. coli indujo la producción de NO con diferencias significativas frente a los controles a partir de concentraciones superiores a $0.001 \mu \mathrm{g} / \mathrm{ml}$, y se comportó como un inductor mucho más potente que el LPS de $E$. coli hasta la concentración de $1 \mu \mathrm{g} / \mathrm{ml}$.

El lípido A de B. abortus también se mostró capaz de inducir la producción de NO, presentando un nivel de inducción significativo desde la concentración de $0.1 \mu \mathrm{g} / \mathrm{ml}$. El lípido A de B. abortus se comportó como un inductor ligeramente más potente que el SLPS. En el caso de B. abortus ensayamos también su polisacárido $\mathrm{O}$ que presentó un nivel de producción de NO muy inferior al presentado por el LPS, lo que nos permite concluir que la porción activa del S-LPS de B. abortus en la inducción de la producción de NO por los macrófagos peritoneales de rata es el lípido A.

El lípido A de B. melitensis fue capaz de inducir la producción de NO a partir de la concentración de $0.1 \mu \mathrm{g} / \mathrm{ml}$. En este caso el lípido A sólo es ligeramente superior al 
LPS a concentraciones altas, sin que lleguen a alcanzar significación estadística las diferencias detectadas entre el lípido A y el S-LPS.

En consecuencia, el lípido A de las brucelas es el componente del LPS que interviene en la inducción de la producción de NO sin existir diferencias significativas a ninguna dosis entre los lípidos A de B. abortus y B. melitensis. Sin embargo, sí existen diferencias significativas entre éstos y el lípido A de E. coli, que se muestra mucho más activo a las concentraciones de 0.01 y $0.1 \mu \mathrm{g} / \mathrm{ml}$ de tal forma que se necesita 100 veces más concentración de los lípidos A de ambas brucelas para alcanzar un nivel similar al inducido por el lípido A de E. coli a las dosis de 0.01 y $0.1 \mu \mathrm{g} / \mathrm{ml}$. Estos resultados coinciden con las observaciones realizadas por Moreno et al. ${ }^{(251)}$ que encuentran que los lípidos A de las enterobacterias presentan una mayor actividad biológica.

Esta menor capacidad de inducción de NO a dosis bajas presentada tanto por los lipopolisacáridos como por los lípidos A de Brucella, respecto al lipopolisacárido y lípido A de E. coli, puede tener implicaciones fisiopatológicas, si tenemos en cuenta que las concentraciones que se alcanzan en condiciones de bacteriemia son inferiores a $1 \mu \mathrm{g} / \mathrm{ml}^{(252 ; 274)}$. Estas diferencias podrían explicar la distinta capacidad de las bacterias gram negativas para producir shock séptico, proceso muy raramente observado en la infección por Brucella.

El shock séptico se caracteriza por un rápido desarrollo de perturbaciones metabólicas, que conducen a daño tisular y muerte a pesar de un óptimo tratamiento médico $^{(273)}$. En esta situación clínica el NO parece jugar un papel patogénico de gran importancia, pues posee una potente actividad vasodilatadora que ha permitido relacionarlo con la vasodilatación e hipotensión observadas en el shock séptico ${ }^{(116)}$. Existen pruebas de su sobreproducción durante la respuesta inflamatoria no regulada que aparece en esta situación patológica ${ }^{(107)}$, y de que la generación de NO está directamente relacionada con el grado de hipotensión existente en el choque endotóxico (275).

Por otra parte la endotoxina bacteriana induce la óxido nítrico sintasa en las células musculares lisas de la vasculatura venosa ${ }^{(276)}$, en el miocardio y en el endocardio ${ }^{(277)}$ y en consecuencia determina una síntesis incrementada de óxido nítrico en el sistema circulatorio que contribuye a la vasodilatación, colapso vascular, daño tisular e inotropismo negativo $^{(278)}$ característico del estado de shock. 
Sobre estas bases podríamos concluir que la vasodilatación e hipotensión existentes durante el shock séptico se producen por la inducción de la vía de alta producción de $\mathrm{NO}^{(116)}$ producida por la endotoxina de las bacterias gram negativas, y que la menor capacidad de los LPSs y lípidos A de Brucella para inducir la NOS podrían explicar la baja frecuencia con que se produce shock séptico en la brucelosis.

\subsection{Los S-LPSs de B. abortus y B. melitensis inducen la producción de NO a través de la vía de la iNOS}

\subsubsection{PERFIL TEMPORAL DE LA INDUCCIÓN}

En el presente estudio se muestra que la inducción de la producción de NO por los lipopolisacáridos de B. abortus y B. melitensis sigue un patrón temporal retrasado, sin que existan diferencias en el efecto producido por los LPS de ambas brucelas, y existiendo también gran similitud con el efecto producido por el LPS de E. coli.

Tanto la magnitud de la liberación de NO inducida por los lipopolisacáridos de B. abortus y B. melitensis como su patrón temporal nos sugería la participación de la forma inducible de la sintasa de NO (iNOS), pues esta enzima requiere varias horas para su expresión en respuesta a los diferentes estímulos, y es capaz de producir cantidades elevadas de NO.

\subsubsection{DEMOSTRACIÓN DE LA PARTICIPACIÓN DE LA VÍA DE LA L-ARGININA}

Nuestros datos son compatibles con que la acumulación de nitritos inducida por los lipopolisacáridos de Brucella se produce a través de la vía de h L-arginina, puesto que la incubación de los macrófagos peritoneales con los LPSs de E. coli, B. abortus y B. melitensis en presencia de $\mathrm{N}^{\mathrm{G}}$-metil-L-arginina, un inhibidor competitivo de la óxido nítrico sintasa, bloquea completamente la producción de NO inducida por los tres lipopolisacáridos.

\subsubsection{INDUCCIÓN DE LA EXPRESIÓN DEL ARNm de iNOS}

En cuanto a la isoforma de la NOS implicada en la respuesta a los lipopolisacáridos de Brucella, nuestros resultados muestran de manera concluyente que se trata de la isoforma inducible o iNOS, a juzgar por la inducción de la expresión del ARNm de esa 
isoforma de la enzima en los macrófagos peritoneales de rata tras la incubación con los lipopolisacáridos de Brucella, con un perfil de dosis y cinética compatible con el observable en la producción de NO, y similar al descrito para el LPS de E. coli.

La producción de NO en respuesta a los tres lipopolisacáridos es demostrable a partir de las 8 horas, lo que concuerda con la necesidad de un periodo de latencia para que se produzca la expresión del ARNm, y ello permite la síntesis de enzima activa necesaria para la producción de NO.

De forma análoga, los lípidos A de E. coli, B. abortus y B. melitensis inducen la expresión del ARNm de iNOS con una potencia superior a la producida por los respectivos lipopolisacáridos, en consonancia con lo observado en los niveles de NO. De esta forma, la producción de NO inducida por los lípidos A se explicaría por la inducción de iNOS.

\subsubsection{INDUCCIÓN DE LA EXPRESIÓN DE LA PROTEÍNA DE iNOS.}

Los hallazgos previos referidos al ARNm de iNOS se confirman también a nivel de proteína, a juzgar por los resultados observados en los experimentos de inmunodetección con anticuerpo específico frente a iNOS. Estos resultados difieren de los referidos en la literatura. Así, en lo que se refiere a la expresión de ARNm o proteína de iNOS por Brucella, sólo Gross et al. ${ }^{(113)}$ han demostrado que Brucella suis opsonizada con suero antibrucella inactivado por calor induce la expresión de ARNm de iNOS cuando se infecta la línea monocítica murina J774A.1, y este efecto se potencia en presencia de IFN $\gamma$. En otras palabras, estos autores sólo obtienen la expresión de proteína iNOS y la producción de NO en las células infectadas con Brucella suis opsonizada con anticuerpos específicos antibrucella, y ello sugiere que el mecanismo de señalización bioquímica implicado en esta inducción pueda ser a través de la estimulación de receptores para la porción Fc de la molécula de anticuerpo, que se ha descrito recientemente como un mecanismo de inducción de iNOS comparable al LPS de E. $\operatorname{coli}^{(279)}$. La potenciación por el interferón gamma en estas condiciones experimentales estaría de acuerdo con el mecanismo de regulación transcripcional de iNOS comúnmente aceptado ${ }^{(47)}$ y que discutimos a continuación. 


\section{Regulación transcripcional de la expresión de iNOS murina}

La regulación transcripcional de la iNOS ha sido objeto de estudios detallados que han permitido establecer los factores de transcripción que participan en el proceso. Así se han identificado en el promotor de iNOS murina dos regiones implicadas respectivamente en la activación transcripcional de este gen por LPS e IFN- $\gamma^{(280 ; 281)}$. La región I contiene elementos relacionados con la respuesta al LPS que incluyen sitios de unión al factor nuclear de la interleucina 6 (NF-IL6), a NF- $\kappa B$ y al elemento de respuesta a TNF (TNF-RE). La región II, contiene motivos de unión para factores de transcripción relacionados con el IFN $\gamma$, tales como el elemento activador por IFN $\gamma /$ PU.1 (PIE), el elemento estimulable por IFN $\gamma$ (ISRE), NF- $\kappa \mathrm{B}$ y AP-1. Las dos regiones son necesarias para conseguir la máxima expresión de estas construcciones. Sin embargo, mientras el LPS es capaz de inducir la expresión de iNOS por sí solo, el IFN $\gamma$ necesita la presencia del LPS para activar la transcripción, de tal manera que la región II parece actuar como un enhancer.

Este hecho demostrado con el LPS de E. coli, parece confirmarse con el S-LPS de las brucelas pues en nuestro sistema fue capaz de inducir la expresión de la iNOS en ausencia de otros estímulos.

Se ha demostrado la participación de NF- $\kappa B$ en la inducción de iNOS por LPS: en macrófagos murinos ${ }^{(282)}$, macrófagos alveolares de rata ${ }^{(283)}$ y en células de músculo liso de ratón y rata. $\mathrm{El} \mathrm{NF}-\kappa \mathrm{B}$ parece ser un elemento necesario pero no suficiente en muchos casos para la inducción de iNOS por LPS. Por otra parte se ha demostrado ${ }^{(284)}$ la activación de NF- $\kappa B$ a través de la estimulación de receptores FçR por complejos inmunes, lo que demostraría la cooperación entre elementos bacterianos y elementos relacionados con la respuesta del huésped para inducir esta respuesta transcripcional implicada en la destrucción bacteriana.

La estimulación de los receptores FcyR induce la expresión de la iNOS en los macrófagos peritoneales ${ }^{(284)}$ y alveolares de rata $^{(285)}$. Mozaffarian et al. ${ }^{(286)}$ han descrito un incremento de la producción de NO en la línea de macrófagos murinos J774.16, al estimular las células con anticuerpos monoclonales y sus correspondientes antígenos en presencia de IFN $\gamma$. Este hecho justificaría la inducción de la expresión de iNOS conseguida por Gross et al. con B. suis opsonizada con anticuerpos específicos. 
El hecho de que no sean necesarios los anticuerpos en nuestro sistema sugiere la participación directa de la interacción de los LPSs de Brucella en la inducción de la expresión de la iNOS.

\subsection{INDUCCIÓN DE NO POR LIPOPOLISACÁRIDOS RELACIONADOS CON EL S-LPS DE Brucella}

Como continuación de los hallazgos precedentes, nos planteamos extender el estudio a los lipopolisacáridos de Escherichia hermannii, Yersinia enterocolitica O:9, Pseudomonas maltophilia 555, y Ochrobactrum anthropi LMG 3331 todos ellos lipopolisacáridos que presentan reacciones serológicas cruzadas con los lipopolisacáridos de Brucella.

El LPS de E. hermannii que presenta reacciones serológicas cruzadas con el S-LPS de Brucella por la estructura similar de su polisacárido $\mathrm{O}$, induce la producción de NO de manera dosis-dependiente. El perfil de su curva dosis respuesta es muy similar al de los S-LPSs de ambas brucelas.

El LPS de Yersinia enterocolitica O:9 que presenta un polisacárido O idéntico a Brucella, tiene una curva dosis respuesta diferente, pues se muestra como un potente inductor a dosis bajas $(0.01$ y $0.1 \mu \mathrm{g} / \mathrm{ml})$.

El LPS de Pseudomonas maltophilia 555 (Stenotrophomonas (Xanthomonas) maltophilia), presenta reacciones serológicas cruzadas con Brucella por poseer su polisacárido $\mathrm{O}$ una estructura relacionada con la del polisacárido $\mathrm{O}$ de Brucella. Su curva dosis-respuesta de inducción de NO es muy similar a la de los LPSs de Brucella.

El S-LPS de Ochrobactrum anthropi no presenta reacciones serológicas cruzadas con Brucella pues su polisacárido $\mathrm{O}$ tiene una estructura diferente. Sin embargo el R-LPS y el lípido A de $O$. anthropi sí que presenta reacciones serológicas cruzadas con el suero de animales infectados con Brucella spp. El S-LPS presenta un perfil de inducción de NO dosis-dependiente muy similar al de los lipopolisacáridos de ambas brucelas.

Así, todos estos lipopolisacáridos que muestran reacciones serológicas cruzadas con los lipopolisacáridos de Brucella son capaces de inducir NO por los macrófagos peritoneales de rata y esta inducción al igual que para los S-LPSs de Brucella se produce por la vía de la óxido nítrico sintasa inducible, a juzgar por la inducción de la expresión de ARNm de iNOS. 
No existen hasta el momento estudios que relacionen estos lipopolisacáridos ni las respectivas bacterias con el óxido nítrico, a excepción de Yersinia enterocolitica, en la que se ha descrito por Dykhuizen et al. ${ }^{(287)}$ que el nitrito acidificado, que conduce a la formación de óxido nítrico, posee actividad antimicrobiana. Debe mencionarse también que Tufano et al. ${ }^{(109)}$ han descrito que las porinas de $Y$. enterocolitica incrementan la producción de nitrito por los monocitos humanos.

\section{4. ÓXIDO NÍTRICO y Brucella}

El NO es una citotoxina poco específica, que ha sido seleccionada por la evolución porque es una molécula lipofílica de pequeño tamaño, a la que pocos microorganismos pueden bloquear su entrada, y porque sus dianas principales (los grupos sulfhidrilo y el hierro) son componentes tan esenciales de la maquinaria bioquímica de la célula que pocos microorganismos podrían mutar hasta hacerse totalmente resistentes. La utilidad del NO es tan grande, que a pesar de los efectos adversos que puede causar, la mayoría de las células están capacitadas para producirlo cuando son activadas adecuadamente por estímulos proinflamatorios o productos microbianos ${ }^{(31)}$.

Las propiedades antimicrobianas del óxido nítrico han sido demostradas fundamentalmente en macrófagos murinos activados en los que se muestra como un mediador citostático y citotóxico importante sobre gran variedad de patógenos incluyendo bacterias, hongos, helmintos y protozoos ${ }^{(69)}$. Además el NO ha sido implicado principalmente en las defensas del huésped frente a patógenos intracelulares $^{(40)}$ como las micobacterias, Leishmania y Plasmodium.

Los macrófagos humanos son células claves para la iniciación y desarrollo de reacciones inmunes e inflamatorias, debido a su capacidad de presentar antígenos y de producir citocinas, radicales libres y mediadores ${ }^{(49 ; 84)}$. A pesar de que la producción de NO por los monocitos/macrófagos humanos ha sido objeto de controversia, ahora existen claras demostraciones de actividad de iNOS por los macrófagos humanos.

Además, ahora tenemos distintas evidencias del papel de los RNI en la actividades antimicrobianas de los macrófagos humanos ${ }^{(69)}$. Así Vouldoukis et al. han demostrado el papel del NO en la muerte de Leishmania major y Leishmania infantum ${ }^{(288)}$ por los macrófagos humanos. La estimulación de CD23, cuya expresión in vivo está incrementada durante la respuesta inmune a antígenos de leishmania, determina la producción de NO y da cuenta de la muerte de los parásitos por los macrófagos 
humanos infectados. Un efecto similar sobre los parásitos, dependiente de NO, fue observado en los macrófagos tratados con IFN $\gamma^{(67)}$. El papel del CD23 en la inducción de la producción de NO ha sido confirmado en los macrófagos peritoneales de rata por Alonso et al. ${ }^{(70)}$ quienes consiguen la inducción de la producción de NO y el incremento en la expresión de la iNOS tras activación del CD23 con inmunocomplejos de IgE y con un anticuerpo policlonal anti-CD23. La activación del factor de transcripción NFkB por estimulación de CD23 ha sido mostrada en el mismo sistema celular por Bayón et al. ${ }^{(71)}$ lo que explica la activación transcripcional del gen de la iNOS y la producción de NO.

Resultados semejantes con Trypanosoma y Toxoplasma confirman el papel del NO en las funciones antimicrobianas de los macrófagos humanos ${ }^{(69)}$.

Denis demuestra la muerte de Mycobacterium avium avirulento y la restricción del crecimiento de Mycobacterium avium virulento por los macrófagos humanos estimulados por TNF- $\alpha$ y por el factor estimulador de colonias de granulocitosmacrófagos a través de un mecanismo en el que participaría el $\mathrm{NO}^{(64)}$.

El NO también participa en la inhibición de Toxoplasma gondii $^{(289)}$ y de Criptococcus neoformans ${ }^{(290)}$ por los astrocitos humanos y también contribuye a la muerte de estafilococos por neutrófilos ${ }^{(291)}$.

Se ha demostrado un efecto antiviral del $\mathrm{NO}$ en las células epiteliales humanas infectadas por virus vaccinia o HSV-1 ${ }^{(292)}$ y su expresión ha sido demostrada en células B infectadas por virus Epstein-Barr, donde parece jugar un papel en la latencia del virus $^{(293)}$. El impacto del NO sobre la infección de VIH es difícil de predecir. El NO puede inhibir la replicación de ciertos virus ${ }^{(61)}$, pero también puede activar el factor de trancripción NF-kB${ }^{(49)}$, el cual tiene el potencial de aumentar la proliferación del VIH. Además, el NO derivado de macrófagos podría contribuir a la disfunción orgánica asociada a $\mathrm{VIH}^{(47)}$, mediando la neurotoxicidad de los pacientes infectados por $\mathrm{VIH}^{(78)}$.

Sin embargo, también existen otros estudios que sugieren que el NO tiene una mínima contribución en la actividad microbicida de los macrófagos humanos contra distintos patógenos como Toxoplasma gondii, Chlamydia psittaci, Leishmania donovani, Criptococcus neoformans y Schistosoma mansoni ${ }^{(14)}$.

Si bien la actividad microbicida del NO derivado de macrófagos humanos, al igual que los murinos, puede contribuir a la protección del huésped frente a diferentes microorganismos, queda mucho por comprender sobre el papel antimicrobiano del sistema NO en los humanos ${ }^{(278)}$. Mientras los macrófagos de roedores responden 
vigorosamente a la combinación IFN $\gamma+\operatorname{LPS}^{(57)}$, las células humanas no responden significativamente a esta combinación de productos $^{(294)}$. De hecho la combinación induce la expresión de ARNm de iNOS pero no produce derivados nitrogenados. Esto sugiere alguna regulación postrancripcional de la síntesis de NO en humanos, de manera que la expresión de iNOS en los monocitos/macrófagos humanos parece estar más estrictamente controlada que en los roedores siendo requeridos otros factores que modifiquen la estabilidad del ARNm y la actividad de la proteína ${ }^{(57)}$.

Además de las acciones microbicidas del NO, también se ha propuesto un posible papel del NO en el mantenimiento de la latencia microbiana ${ }^{(51)}$ basado en la capacidad del NO de mediar un largo estado de microbiostasis en muchos sistemas experimentales. Está claro que la infección latente requiere la supresión activa por los mecanismos celulares inmunes, pues la acción de drogas inmunosupresoras o enfermedades conduce a la reactivación de la infección. El mecanismo por el que la supresión de la infección latente puede ser mantenido sin signos patentes de inflamación y enfermedad en el huésped permanece como uno de los aspectos no entendidos de la patogénesis microbiana. Sin embargo, recientemente se ha demostrado que la inhibición de la producción de NO induce la pronta reactivación de Leishmania major ${ }^{(12)}$, M. tuberculosis, virus Epstein-Barr ${ }^{(293)}$ y Toxoplasma gondii $^{(295)}$ en modelos experimentales $^{(76)}$, sugiriendo que el NO puede jugar un papel central en las infecciones latentes o persistentes.

Por lo que antecede, resulta de sumo interés la relación que pueda existir entre Brucella, que es una bacteria capaz de sobrevivir en el interior de las células fagocíticas y la producción de óxido nítrico.

Los estudios sobre la producción de NO y Brucella son escasos. Jiang et al. ${ }^{(188)}$ no detectan la producción de nitrito en el medio de cultivo de macrófagos J774A.1 tratados con IFN $\gamma$ e infectados con B. abortus opsonizada. Sin embargo, sí detectan la producción de nitrito cuando utilizan macrófagos peritoneales. Esto resultados difieren de los obtenidos por Gross et al. ${ }^{(113)}$ que consiguen la producción de NO por macrófagos de la línea celular J774A.1 pretratados con IFNy e infectados con B. suis opsonizada. Estos autores justifican sus diferentes resultados por las distintas cepas y anticuerpos opsonizantes utilizados, pues mientras ellos utilizan una cepa virulenta de B. suis y anticuerpos de ratón inmunizado con esta cepa, Jiang et al. utilizan la cepa avirulenta B. abortus 19 y anticuerpos de suero bovino inmunizado con la misma. 
Zhan et al. ${ }^{(296)}$ observaron una fuerte producción de NO en las células esplénicas de ratones control infectados con B. abortus, que no se detecta en los esplenocitos de ratones no infectados, y que se ve disminuida en los ratones tratados con anti-IL-12. Demuestran que la interleucina-12 está implicada en la resistencia a la infección por B. abortus, pues se produce una exacerbación de la infección en los ratones tratados con anticuerpo monoclonal anti-IL-12(297) . Esta exacerbación de la infección la justifican por el hecho de que existe una producción disminuida de IFN $\gamma$ por las células T esplénicas de los ratones así tratados, ya que habían demostrado previamente que el IFN $\gamma$ participaba en la resistencia a la infección por B. abortus $^{(298)}$, hecho encontrado también por Jiang ${ }^{(272)}$ y otros autores ${ }^{(299)}$. Zhan et al. explican la producción reducida de NO por las células esplénicas de los ratones tratados con anti-IL-12 por la ausencia de IFN $\gamma$ que active a los macrófagos para su producción ${ }^{(296)}$. Aunque estos autores no lo consideran, creemos que debe tenerse en cuenta un posible papel en la exacerbación de la infección, no sólo de la producción disminuida de IFNy sino también de la consecuente producción disminuida de NO puesto que es una molécula que como hemos visto puede presentar acciones antimicrobianas.

Zhan et al. ${ }^{(297)}$ también encuentran que cuando se utilizan brucelas muertas por calor como estímulos sobre células esplénicas obtenidas de ratones infectados con B. abortus, se produce un nivel más alto de nitrito que cuando se utilizan listerias muertas por calor o no se utilizan estímulos. Este hecho podría ser debido al efecto activante del IFN $\gamma$ sobre la producción de NO, pues también las brucelas muertas por calor producen un mayor nivel del mismo. En nuestro estudio hemos observado que el lipopolisacárido de Brucella es capaz de inducir la producción de $\mathrm{NO}$ en los macrófagos peritoneales de rata, con lo cual se podría explicar la mayor inducción de NO encontrada por estos autores cuando utilizan brucelas como estímulos.

En cuanto al papel bactericida del NO sobre las brucelas, Jiang et al. ${ }^{(188)}$ encuentran que la adición de L-NMA, un inhibidor competitivo de la iNOS, produce un aumento significativo en el número de UFC recuperadas de los macrófagos peritoneales infectados justo después de ser aislados de la cavidad peritoneal, independientemente de la presencia o no de IFN $\gamma$; este resultado estaría de acuerdo con un efecto antibrucella del NO. Sin embargo, cuando los macrófagos tratados 24 horas antes de la infección con IFN $\gamma$, es decir macrófagos que han sido máximamente activados, son tratados con L-NMA no sólo no se produce un aumento en el número de UFC recuperadas, sino 
que disminuye su número sugiriendo una regulación negativa del NO sobre la producción de ROI. Por otra parte la adición de inhibidores de los ROI, concretamente superóxidodismutasa y catalasa, bloquea la actividad antibrucela de los macrófagos peritoneales, si bien no de forma completa. Estos autores concluyen que los ROI juegan un papel importante en la actividad antibrucella de los macrófagos, mientras que atribuyen un menor papel al óxido nítrico.

Gross et al. ${ }^{(113)}$ demuestran un efecto bactericida directo (in vitro) del NO sobre Brucella suis mediante la adición de SIN-1, un compuesto donador de radicales NO, al medio de cultivo de las brucelas. Además encuentran que sólo los macrófagos murinos tratados con IFN $\gamma$ e infectados con Brucella suis opsonizada con anticuerpos antibrucela son capaces de expresar iNOS funcional y de producir NO, lo que es coincidente con otros estudios en los que la estimulación de receptores $\mathrm{Fc} \gamma \mathrm{R}$ induce la expresión de iNOS $^{(286)}$. En los macrófagos así infectados, la adición de un inhibidor de la iNOS determina un mayor número de bacterias viables. De este modo se demostraría que el NO es un componente de la actividad antibrucela de los macrófagos murinos si bien sólo en las condiciones indicadas. Estas condiciones, producción de IFN $\gamma$ y presencia de anticuerpos específicos, podrían presentarse in vivo en ratones inmunizados $o$ infectados durante semanas por la bacteria viva, que de este modo serían resistentes a la infección a través de la producción de NO, mientras que el establecimiento de la primoinfección podría estar facilitado por la ausencia de producción de NO. Además estos autores no obtienen evidencia de la producción de NO en los fagocitos mononucleares humanos infectados con $B$. suis y sugieren que estas diferencias podrían explicar en parte por que las infecciones de Brucella se convierten en crónicas en los humanos y rumiantes pero no en los ratones.

En un acercamiento al complejo proceso todavía no comprendido de la capacidad de Brucella de resistir los mecanismos bactericidas y de sobrevivir en el interior de las células fagocíticas y al complicado papel (tanto bactericida como posiblemente en la latencia microbiana) del óxido nítrico en los sistemas biológicos, nosotros aportamos la evidencia de que el S-LPS de Brucella es capaz de inducir la producción de NO a través de la vía de la oxido nítrico sintasa inducible en los macrófagos peritoneales de rata.

Por una parte, el hecho de que el LPS sea capaz de inducir la producción de NO en los macrófagos murinos, podría justificar, por que en los ratones la brucelosis no es una 
infección crónica como ocurre en el caso de los humanos. Por otra parte, la menor producción de NO inducida tanto por el LPS como por el lípido A de B. abortus y B. melitensis respecto al LPS de E. coli a dosis bajas (inferiores a $1 \mu \mathrm{g} / \mathrm{ml}$ que podrían ser próximas a las fisiológicas), justificaría la baja frecuencia con que se presenta el cuadro de shock séptico en la brucelosis humana y podrían justificar en parte su mecanismo de supervivencia intracelular. 
VI. CONCLUSIONES 
1.- Los S-LPSs de Brucella abortus 544 y Brucella melitensis 16M inducen la producción de óxido nítrico en los macrófagos peritoneales de rata, de manera dosis y tiempo dependiente.

2.- El nivel de NO inducido por los S-LPSs de B. abortus 544 y B. melitensis $16 \mathrm{M}$ a las concentraciones de 0.01 y $0.1 \mu \mathrm{g} / \mathrm{ml}$ es significativamente inferior al inducido por el LPS de E. coli, no existiendo diferencias entre los S-LPSs de ambas brucelas.

3.- Los lípidos A de E. coli, B. abortus y B. melitensis inducen la producción de NO de manera dosis dependiente, comportándose como la parte activa del LPS en dicha inducción.

4.- Los lípidos A de ambas brucelas se comportan como inductores menos potentes que el lípido A de E. coli a las concentraciones de 0.01 y $0.1 \mu \mathrm{g} / \mathrm{ml}$, no existiendo diferencias entre los lípidos A de ambas brucelas

5.- La inducción de NO por los lipopolisacáridos y lípidos A de E. coli, B. abortus y B. melitensis en los macrófagos de rata es inhibida en presencia del inhibidor específico de la iNOS, $\mathrm{N}^{\mathrm{G}}$-metil-L-arginina.

6.- Los S-LPSs de B. abortus y B. melitensis inducen la producción de NO en macrófagos peritoneales de rata mediante la inducción de la transcripción y síntesis de la isoforma inducible de la óxido nítrico sintasa (iNOS).

7.- Los lípidos A de E. coli, B. abortus y B. melitensis inducen la producción de NO en macrófagos peritoneales de rata mediante la inducción de la transcripción de la iNOS.

8.- Los lipopolisacáridos de Escherichia hermannii, Yersinia enterocolitica O:9, Pseudomonas maltophilia 555 y Ochrobactrum anthropi LMG 3331, son capaces de inducir la producción de NO en los macrófagos peritoneales de rata de manera dosis dependiente, e inducen la trancripción de la iNOS. 


\section{BIBLIOGRAFÍA}


1. Sanfilippo, F., Balber, A.E., Granger D.L. and MckKinney R.E. Respuestas inmunitarias contra la infección. In: Zinsser Microbiología, edited by Joklik W.K., Willet H.P., Amos D.B. and Wilfert C.M. Editorial Medica Panamericana, 1994, p. 477-511.

2. Abbas, A.K., Lichtman, A.H. and Pober, J.S. Mecanismos efectores de las respuestas inmunitarias. In: Inmunología Celular y Molecular, Interamericana. McGraw-Hill, 1995,

3. Host Defenses. In: Medical Microbiology \& Immunology. Examination \& Board Review, edited by Levinson, W.E. and Jawetz, E. Appleton \& Lange, 1994, p. 33-37.

4. Rook, G. Inmunidad frente a virus, bacterias y hongos. In: Inmunología, edited by Roitt, I.M., Brostoff, J. and Male, D.K. Salvat Editores,S.A., 1991, p. 16.1-16.14

5. Lorenzo Vidal, Belén. Contribución al estudio de la explosión oxidativa en polimorfonucleares neutrófilos y monocitos humanos inducida por Brucella. 1996. Universidad de Valladolid. Tesis.

6. Spitznagel, J.K. Defensas constitutivas del cuerpo. In: Microbiología. Mecanismos de las enfermedades infecciosas. Enfoque mediante resolución de problemas., edited by Schaechter, M., Medoff, G., Eisenstein, B.I. and Guerra, H. Editorial Médica Panamericana S.A., 1994, p. 110-132.

7. Horwitz, M.A. Phagocytosis of microorganisms. Rev Infect Dis 4:104-123, 1982.

8. Nonspecific Defenses of the Host. In: Microbiology: an Introduction, edited by Tortora, G.J., Funke, B.R. and Case, C.L. The Benjamin/Cummings Publishing Company, Inc., 1995, p. 406-424.

9. Klebanoff, S.J. Phagocytic Cells: Products of Oxygen Metabolism. In: Inflammation: Basic Principles and Clinical Correlates, edited by Gallin, J.I., Goldstein, I.M. and Snyderman, R. Raven Press,Ltd., 1988, p. 391444.

10. El crecimiento y su control. In: Microbiología, edited by Brock, T.D. and Madigan, M.T. Prentince Hall Hispanoamericana S.A., 1993, p. 327-371.

11. Roos, D., Eckmann, C.M., Yazdanbakhsh, M., Hamers, M.N. and de Boer, M. Excretion of superoxide by phagocytes measured with cytochrome c entrapped in resealed erythrocyte ghosts. J Biol Chem 259:1770-1775, 1984.

12. Haas, A. and Goebel, W. Microbial strategies to prevent oxygen-dependent killing by phagocytes. Free Radic Res Commun 16:137-157, 1992.

13. Kuo, C.F., Mashino, T. and Fridovich, I. alpha, beta-Dihydroxyisovalerate dehydratase. A superoxide-sensitive enzyme. J Biol Chem 262:4724-4727, 1987.

14. Miller, R.A. and Britigan, B.E. Role of oxidants in microbial pathophysiology. Clin Microbiol Rev 10:1-18, 1997.

15. Bielski, B.H., Arudi, R.L. and Sutherland, M.W. A study of the reactivity of HO2/O2- with unsaturated fatty acids. J Biol Chem 258:4759-4761, 1983.

16. Weiss, S.J. Oxygen, ischemia and inflammation. Acta Physiol Scand Suppl 548:9-37:9-37, 1986.

17. Haber, F. and Weiss, J. The catalytic decomposition of hydrogen peroxide by iron salts. Proc.R.Soc.Lond. 147:332-351, 1934.

18. Gutteridge, J.M. and Wilkins, S. Copper salt-dependent hydroxyl radical formation. Damage to proteins acting as antioxidants. Biochim Biophys Acta 759:38-41, 1983. 
19. Kane, A.B. Mechanisms of Cell and Tissue Injury. In: Cellular and Molecular Pathogenesis, edited by Sirica, A.E. Lippincott-Raven, 1996, p. 1-22.

20. Buettner, G.R. The pecking order of free radicals and antioxidants: lipid peroxidation, alpha-tocopherol, and ascorbate. Arch Biochem Biophys 300:535-543, 1993.

21. Hurst, J.K. and Barrette, W.C.J. Leukocytic oxygen activation and microbicidal oxidative toxins. Crit.Rev Biochem Mol Biol 24:271-328, 1989.

22. Heifets, L., Imai, K. and Goren, M.B. Expression of peroxidase-dependent iodination by macrophages ingesting neutrophil debris. J Reticuloendothel.Soc 28:391-404, 1980.

23. Gordon, S., Todd, J. and Cohn, Z.A. In vitro synthesis and secretion of lysozyme by mononuclear phagocytes. J Exp Med 139:1228-1248, 1974.

24. Ambruso, D.R. and Johnston, R.B.J. Lactoferrin enhances hydroxyl radical production by human neutrophils, neutrophil particulate fractions, and an enzymatic generating system. J Clin Invest 67:352-360, 1981.

25. Britigan, B.E., Rosen, G.M., Thompson, B.Y., Chai, Y. and Cohen, M.S. Stimulated human neutrophils limit iron-catalyzed hydroxyl radical formation as detected by spin-trapping techniques. J Biol Chem 261:1702617032, 1986.

26. Elsbach, P. and Weiss, J. Phagocytic Cells: Oxigen-Independent Antimicrobial Systems. In: Inflammation: Basic Principles and Clinical Correlates, edited by Gallin, J.I., Goldstein, I.M. and Snyderman, R. Raven Press,Ltd., 1988, p. 445-470.

27. Cherwonodgrodzky, J.W., Dubray, G., Moreno, E. and Mayer, H. Antigens of Brucella. In: Animal Brucellosis, edited by Nielsen, K. and Duncan, J.R. CRC Press, Inc, 1990, p. 20-64.

28. Hancock, R.E. Alterations in outer membrane permeability. Annu Rev Microbiol 38:237-64:237-264, 1984.

29. Relaciones huésped-parásito. In: Microbiología, edited by Brock, T.D. and Madigan, M.T. Prentince Hall Hispanoamericana S.A., 1993, p. 415-456.

30. Schmidt, H.H. and Walter, U. NO at work. Cell 78:919-925, 1994.

31. MacMicking, J., Xie, Q.W. and Nathan, C. Nitric oxide and macrophage function. Annu.Rev.Immunol. 15:32350:323-350, 1997.

32. Palmer, R.M., Ferrige, A.G. and Moncada, S. Nitric oxide release accounts for the biological activity of endothelium-derived relaxing factor. Nature 327:524-526, 1987.

33. Nathan, C.F. and Hibbs, J.B. Role of nitric oxide synthesis in macrophage antimicrobial activity. Curr Opin Immunol 3:65-70, 1991.

34. Hibbs, J.B., Taintor, R.R., Vavrin, Z. and Rachlin, E.M. Nitric oxide: a cytotoxic activated macrophage effector molecule [published erratum appears in Biochem Biophys Res Commun 1989 Jan 31;158(2):624]. Biochem Biophys Res Commun 157:87-94, 1988.

35. Bredt, D.S., Hwang, P.M. and Snyder, S.H. Localization of nitric oxide synthase indicating a neural role for nitric oxide. Nature 347:768-770, 1990.

36. Garthwaite, J., Charles, S.L. and Chess-Williams, R. Endothelium-derived relaxing factor release on activation of NMDA receptors suggests role as intercellular messenger in the brain. Nature 336:385-388, 1988.

37. Snyder, S.H. and Bredt, D.S. Nitric oxide as a neuronal messenger. Trends Pharmacol Sci 12:125-128, 1991. 
38. Stuehr, D.J., Kwon, N.S., Nathan, C.F., Griffith, O.W., Feldman, P.L. and Wiseman, J. N omega-hydroxy-Larginine is an intermediate in the biosynthesis of nitric oxide from L-arginine. J Biol Chem 266:6259-6263, 1991.

39. Griffith, O.W. and Stuehr, D.J. Nitric oxide synthases: properties and catalytic mechanism. Annu Rev Physiol 57:707-736, 1995.

40. Fang, F.C. Perspectives series: host/pathogen interactions. Mechanisms of nitric oxide-related antimicrobial activity. J Clin Invest 99:2818-2825, 1997.

41. Eiserich, J.P., Cross, C.E., Jones, A.D., Halliwell, B. and van der Vliet, A. Formation of nitrating and chlorinating species by reaction of nitrite with hypochlorous acid. A novel mechanism for nitric oxide-mediated protein modification. J Biol Chem 271:19199-19208, 1996.

42. Gow, A.J., Buerk, D.G. and Ischiropoulos, H. A novel reaction mechanism for the formation of S-nitrosothiol in vivo. J Biol Chem 272:2841-2845, 1997.

43. Bredt, D.S., Hwang, P.M., Glatt, C.E., Lowenstein, C., Reed, R.R. and Snyder, S.H. Cloned and expressed nitric oxide synthase structurally resembles cytochrome P-450 reductase. Nature 351:714-718, 1991.

44. Xie, Q.W., Leung, M., Fuortes, M., Sassa, S. and Nathan, C. Complementation analysis of mutants of nitric oxide synthase reveals that the active site requires two hemes. Proc.Natl.Acad.Sci.U.S.A. 93:4891-4896, 1996.

45. Schoedon, G., Schneemann, M., Walter, R., Blau, N., Hofer, S. and Schaffner, A. Nitric oxide and infection: another view. Clin Infect Dis 21 Suppl 2:S152-7:S152-S1571995.

46. Sessa, W.C., Harrison, J.K., Barber, C.M., et al. Molecular cloning and expression of a cDNA encoding endothelial cell nitric oxide synthase. J Biol Chem 267:15274-15276, 1992.

47. Nathan, C. and Xie, Q.W. Nitric oxide synthases: roles, tolls, and controls. Cell 78:915-918, 1994.

48. Moncada, S., Higgs, A. and Furchgott, R. International Union of Pharmacology Nomenclature in Nitric Oxide Research. Pharmacol Rev 49:137-142, 1997.

49. Nathan, C. Nitric oxide as a secretory product of mammalian cells. FASEB J 6:3051-3064, 1992.

50. James, S.L. Role of nitric oxide in parasitic infections. Microbiol Rev 59:533-547, 1995.

51. De Groote, M.A. and Fang, F.C. NO inhibitions: antimicrobial properties of nitric oxide. Clin Infect Dis 21 Suppl 2:S162-5:S162-S1651995.

52. Green, S.J., Scheller, L.F., Marletta, M.A., et al. Nitric oxide: cytokine-regulation of nitric oxide in host resistance to intracellular pathogens. Immunol Lett 43:87-94, 1994.

53. Riches, D.W. and Underwood, G.A. Expression of interferon-beta during the triggering phase of macrophage cytocidal activation. Evidence for an autocrine/paracrine role in the regulation of this state. J Biol Chem 266:24785-24792, 1991.

54. Xie, Q.W., Cho, H.J., Calaycay, J., et al. Cloning and characterization of inducible nitric oxide synthase from mouse macrophages. Science 256:225-228, 1992.

55. Xie, Q.W., Kashiwabara, Y. and Nathan, C. Role of transcription factor NF-kappa B/Rel in induction of nitric oxide synthase. J Biol Chem 269:4705-4708, 1994.

56. Martin, E., Nathan, C. and Xie, Q.W. Role of interferon regulatory factor 1 in induction of nitric oxide synthase. J Exp Med 180:977-984, 1994. 
57. Dugas, B., Debre, P. and Moncada, S. Nitric oxide, a vital poison inside the immune and inflammatory network. Res Immunol 146:664-670, 1995.

58. Vodovotz, Y. and Bogdan, C. Control of nitric oxide synthase expression by transforming growth factor-beta: implications for homeostasis. Prog Growth Factor Res 5:341-351, 1994.

59. Perrella, M.A., Hsieh, C.M., Lee, W.S., et al. Arrest of endotoxin-induced hypotension by transforming growth factor beta1. Proc Natl Acad Sci U S A 93:2054-2059, 1996.

60. Albakri, Q.A. and Stuehr, D.J. Intracellular assembly of inducible NO synthase is limited by nitric oxidemediated changes in heme insertion and availability. J Biol Chem 271:5414-5421, 1996.

61. Nathan, C. and Xie, Q.W. Regulation of biosynthesis of nitric oxide. J Biol.Chem. 269:13725-13728, 1994.

62. Nussler, A.K. and Billiar, T.R. Inflammation, immunoregulation, and inducible nitric oxide synthase. J Leukoc Biol 54:171-178, 1993.

63. Hibbs, J.B.J., Westenfelder, C., Taintor, R., et al. Evidence for cytokine-inducible nitric oxide synthesis from Larginine in patients receiving interleukin-2 therapy [published erratum appears in J Clin Invest 1992 Jul;90(1):295]. J Clin Invest 89:867-877, 1992.

64. Denis, M. Tumor necrosis factor and granulocyte macrophage-colony stimulating factor stimulate human macrophages to restrict growth of virulent Mycobacterium avium and to kill avirulent M. avium: killing effector mechanism depends on the generation of reactive nitrogen intermediates. J Leukoc Biol 49:380-387, 1991.

65. Testi, R., Cifone, M.G. and Santoni, A. Role of CD69 in NO production by human monocytes. Res Immunol 146:682-683, 1995.

66. De Maria, R., Cifone, M.G., Trotta, R., et al. Triggering of human monocyte activation through CD69, a member of the natural killer cell gene complex family of signal transducing receptors. J Exp Med 180:19992004, 1994.

67. Vouldoukis, I., Riveros-Moreno, V., Dugas, B., et al. The killing of Leishmania major by human macrophages is mediated by nitric oxide induced after ligation of the Fc epsilon RII/CD23 surface antigen. Proc Natl Acad Sci U S A 92:7804-7808, 1995.

68. Mossalayi, M.D., Paul-Eugene, N., Ouaaz, F., et al. Involvement of Fc epsilon RII/CD23 and L-argininedependent pathway in IgE-mediated stimulation of human monocyte functions. Int Immunol 6:931-934, 1994.

69. Vouldoukis, I., Mazier, D., Debre, P. and Mossalayi, M.D. Nitric oxide and human infectious diseases. Res Immunol 146:689-692, 1995.

70. Alonso, A., Carvalho, J., Alonso-Torre, S.R., Nunez, L., Bosca, L. and Sanchez, C.M. Nitric oxide synthesis in rat peritoneal macrophages is induced by IgE/DNP complexes and cyclic AMP analogues. Evidence in favor of a common signaling mechanism. J.Immunol. 154:6475-6483, 1995.

71. Bayon, Y., Alonso, A. and Sanchez, C.M. Immunoglobulin-E/dinitrophenyl complexes induce nitric oxide synthesis in rat peritoneal macrophages by a mechanism involving CD23 and NF-kappaB activation. Biochem Biophys Res Commun 242:570-574, 1998.

72. St Clair, E.W., Wilkinson, W.E., Lang, T., et al. Increased expression of blood mononuclear cell nitric oxide synthase type 2 in rheumatoid arthritis patients. J Exp Med 184:1173-1178, 1996. 
73. Condino-Neto, A., Muscara, M.N., Grumach, A.S., Carneiro-Sampaio, M.M. and De Nucci, G. Neutrophils and mononuclear cells from patients with chronic granulomatous disease release nitric oxide. Br J Clin Pharmacol 35:485-490, 1993.

74. Anstey, N.M., Weinberg, J.B., Hassanali, M.Y., et al. Nitric oxide in Tanzanian children with malaria: inverse relationship between malaria severity and nitric oxide production/nitric oxide synthase type 2 expression. $J$ Exp Med 184:557-567, 1996.

75. Nicholson, S., Bonecini-Almeida, M.d., Lapa, et al. Inducible nitric oxide synthase in pulmonary alveolar macrophages from patients with tuberculosis. J Exp Med 183:2293-2302, 1996.

76. MacMicking, J.D., North, R.J., LaCourse, R., Mudgett, J.S., Shah, S.K. and Nathan, C.F. Identification of nitric oxide synthase as a protective locus against tuberculosis. Proc Natl Acad Sci U S A 94:5243-5248, 1997.

77. Kumar, V., Jindal, S.K. and Ganguly, N.K. Release of reactive oxygen and nitrogen intermediates from monocytes of patients with pulmonary tuberculosis. Scand J Clin Lab Invest 55:163-169, 1995.

78. Bukrinsky, M.I., Nottet, H.S., Schmidtmayerova, H., et al. Regulation of nitric oxide synthase activity in human immunodeficiency virus type 1 (HIV-1)-infected monocytes: implications for HIV- associated neurological disease. J Exp Med 181:735-745, 1995.

79. Shenep, J.L. and Tuomanen, E. Perspective: targeting nitric oxide in the adjuvant therapy of sepsis and meningitis. J Infect Dis 177:766-769, 1998.

80. Evans, T.J., Buttery, L.D., Carpenter, A., Springall, D.R., Polak, J.M. and Cohen, J. Cytokine-treated human neutrophils contain inducible nitric oxide synthase that produces nitration of ingested bacteria. Proc Natl Acad Sci U S A 93:9553-9558, 1996.

81. Wheeler, M.A., Smith, S.D., Garcia-Cardena, G., Nathan, C.F., Weiss, R.M. and Sessa, W.C. Bacterial infection induces nitric oxide synthase in human neutrophils. J Clin Invest 99:110-116, 1997.

82. Azuma, H., Ishikawa, M. and Sekizaki, S. Endothelium-dependent inhibition of platelet aggregation. $B r J$ Pharmacol 88:411-415, 1986.

83. Radomski, M.W., Palmer, R.M. and Moncada, S. The role of nitric oxide and cGMP in platelet adhesion to vascular endothelium. Biochem Biophys Res Commun 148:1482-1489, 1987.

84. Moncada, S., Palmer, R.M. and Higgs, E.A. Nitric oxide: physiology, pathophysiology, and pharmacology. Pharmacol Rev 43:109-142, 1991.

85. Kilbourn, R.G., Gross, S.S., Jubran, A., et al. NG-methyl-L-arginine inhibits tumor necrosis factor-induced hypotension: implications for the involvement of nitric oxide. Proc Natl Acad Sci U S A 87:3629-3632, 1990.

86. O'Dell, T.J., Hawkins, R.D., Kandel, E.R. and Arancio, O. Tests of the roles of two diffusible substances in long-term potentiation: evidence for nitric oxide as a possible early retrograde messenger. Proc Natl Acad Sci U S A 88:11285-11289, 1991.

87. Garthwaite, J., Garthwaite, G., Palmer, R.M. and Moncada, S. NMDA receptor activation induces nitric oxide synthesis from arginine in rat brain slices. Eur J Pharmacol 172:413-416, 1989.

88. Schuman, E.M. and Madison, D.V. A requirement for the intercellular messenger nitric oxide in long-term potentiation. Science 254:1503-1506, 1991. 
89. Bult, H., Boeckxstaens, G.E., Pelckmans, P.A., Jordaens, F.H., Van Maercke, Y.M. and Herman, A.G. Nitric oxide as an inhibitory non-adrenergic non-cholinergic neurotransmitter [see comments]. Nature 345:346-347, 1990.

90. Halbrugge, T., Lutsch, K., Thyen, A. and Graefe, K.H. Vasodilatation by endothelium-derived nitric oxide as a major determinant of noradrenaline release. J Neural Transm Suppl 34:113-119, 1991.

91. O'Sullivan, A.J. and Burgoyne, R.D. Cyclic GMP regulates nicotine-induced secretion from cultured bovine adrenal chromaffin cells: effects of 8-bromo-cyclic GMP, atrial natriuretic peptide, and nitroprusside (nitric oxide). J Neurochem 54:1805-1808, 1990.

92. Lander, H.M., Sehajpal, P., Levine, D.M. and Novogrodsky, A. Activation of human peripheral blood mononuclear cells by nitric oxide-generating compounds. J Immunol 150:1509-1516, 1993.

93. Florquin, S., Amraoui, Z., Dubois, C., Decuyper, J. and Goldman, M. The protective role of endogenously synthesized nitric oxide in staphylococcal enterotoxin B-induced shock in mice. J Exp Med 180:1153-1158, 1994.

94. Taylor-Robinson, A.W., Liew, F.Y., Severn, A., et al. Regulation of the immune response by nitric oxide differentially produced by T helper type 1 and T helper type 2 cells. Eur J Immunol 24:980-984, 1994.

95. Albina, J.E., Abate, J.A. and Henry, W.L. Nitric oxide production is required for murine resident peritoneal macrophages to suppress mitogen-stimulated T cell proliferation. Role of IFN-gamma in the induction of the nitric oxide-synthesizing pathway. J Immunol 147:144-148, 1991.

96. Holt, P.G., Oliver, J., Bilyk, N., et al. Downregulation of the antigen presenting cell function(s) of pulmonary dendritic cells in vivo by resident alveolar macrophages. J Exp Med 177:397-407, 1993.

97. Swallow, C.J., Grinstein, S., Sudsbury, R.A. and Rotstein, O.D. Nitric oxide derived from L-arginine impairs cytoplasmic $\mathrm{pH}$ regulation by vacuolar-type $\mathrm{H}+$ ATPases in peritoneal macrophages. J Exp Med 174:10091021,1991

98. Kubes P. and Wallace J.L. Nitric oxide as a mediator of gastrointestinal mucosal injury?- Say it ain't so. Mediators of Inflamations 4:397-405, 1995.

99. Hogaboam, C.M., Befus, A.D. and Wallace, J.L. Modulation of rat mast cell reactivity by IL-1 beta. Divergent effects on nitric oxide and platelet-activating factor release. J Immunol 151:3767-3774, 1993.

100. Salvemini, D., Masini, E., Anggard, E., Mannaioni, P.F. and Vane, J. Synthesis of a nitric oxide-like factor from L-arginine by rat serosal mast cells: stimulation of guanylate cyclase and inhibition of platelet aggregation. Biochem Biophys Res Commun 169:596-601, 1990.

101. Griscavage, J.M., Rogers, N.E., Sherman, M.P. and Ignarro, L.J. Inducible nitric oxide synthase from a rat alveolar macrophage cell line is inhibited by nitric oxide. J Immunol 151:6329-6337, 1993.

102. Zingarelli, B., O'Connor, M., Wong, H., Salzman, A.L. and Szabo, C. Peroxynitrite-mediated DNA strand breakage activates poly-adenosine diphosphate ribosyl synthetase and causes cellular energy depletion in macrophages stimulated with bacterial lipopolysaccharide. J Immunol 156:350-358, 1996.

103. Genaro, A.M., Hortelano, S., Alvarez, A., Martinez, C. and Bosca, L. Splenic B lymphocyte programmed cell death is prevented by nitric oxide release through mechanisms involving sustained Bcl-2 levels. J Clin Invest 95:1884-1890, 1995. 
104. Messmer, U.K., Ankarcrona, M., Nicotera, P. and Brune, B. p53 expression in nitric oxide-induced apoptosis. FEBS Lett 355:23-26, 1994.

105. Miller M.J.S. and Grisham M.B. Nitric oxide as a mediator of inflammation?- You had better believe it. Mediators of Inflammation 4:387-396, 1995.

106. Nathan, C. Inducible nitric oxide synthase: what difference does it make? J Clin Invest 100:2417-2423, 1997.

107. English, B.K., Patrick, C.C., Orlicek, S.L., McCordic, R. and Shenep, J.L. Lipoteichoic acid from viridans streptococci induces the production of tumor necrosis factor and nitric oxide by murine macrophages. J Infect Dis 174:1348-1351, 1996.

108. Cunha, F.Q., Moss, D.W., Leal, L.M., Moncada, S. and Liew, F.Y. Induction of macrophage parasiticidal activity by Staphylococcus aureus and exotoxins through the nitric oxide synthesis pathway. Immunology 78:563-567, 1993.

109. Tufano, M.A., Rossano, F., Catalanotti, P., et al. Properties of Yersinia enterocolitica porins: interference with biological functions of phagocytes, nitric oxide production and selective cytokine release . Res Microbiol 145:297-307, 1994.

110. Evans, T.G., Thai, L., Granger, D.L. and Hibbs, J.B.J. Effect of in vivo inhibition of nitric oxide production in murine leishmaniasis. J Immunol 151:907-915, 1993.

111. Ochoa, J.B., Udekwu, A.O., Billiar, T.R., et al. Nitrogen oxide levels in patients after trauma and during sepsis. Ann Surg 214:621-626, 1991.

112. Stenger, S., Donhauser, N., Thuring, H., Rollinghoff, M. and Bogdan, C. Reactivation of latent leishmaniasis by inhibition of inducible nitric oxide synthase. J Exp Med 183:1501-1514, 1996.

113. Gross, A., Spiesser, S., Terraza, A., Rouot, B., Caron, E. and Dornand, J. Expression and bactericidal activity of nitric oxide synthase in Brucella suis-infected murine macrophages. Infect Immun 66:1309-1316, 1998.

114. Boockvar, K.S., Granger, D.L., Poston, R.M., et al. Nitric oxide produced during murine listeriosis is protective. Infect Immun 62:1089-1100, 1994.

115. Gregory, S.H., Wing, E.J., Hoffman, R.A. and Simmons, R.L. Reactive nitrogen intermediates suppress the primary immunologic response to Listeria. J Immunol 150:2901-2909, 1993.

116. MacMicking, J.D., Nathan, C., Hom, G., et al. Altered responses to bacterial infection and endotoxic shock in mice lacking inducible nitric oxide synthase [published erratum appears in Cell 1995 Jun 30;81(7):following 1170]. Cell 81:641-650, 1995.

117. Fehr, T., Schoedon, G., Odermatt, B., et al. Crucial role of interferon consensus sequence binding protein, but neither of interferon regulatory factor 1 nor of nitric oxide synthesis for protection against murine listeriosis. $J$ Exp Med 185:921-931, 1997.

118. Scharton-Kersten, T., Nakajima, H., Yap, G., Sher, A. and Leonard, W.J. Infection of mice lacking the common cytokine receptor gamma-chain (gamma(c)) reveals an unexpected role for CD4+ T lymphocytes in early IFNgamma-dependent resistance to Toxoplasma gondii. J Immunol 160:2565-2569, 1998.

119. Akaike, T., Noguchi, Y., Ijiri, S., et al. Pathogenesis of influenza virus-induced pneumonia: involvement of both nitric oxide and oxygen radicals. Proc Natl Acad Sci U S A 93:2448-2453, 1996.

120. Doherty, T.M. and Sher, A. Defects in cell-mediated immunity affect chronic, but not innate, resistance of mice to Mycobacterium avium infection. J Immunol 158:4822-4831, 1997. 
121. Nunoshiba, T., deRojas-Walker, T., Wishnok, J.S., Tannenbaum, S.R. and Demple, B. Activation by nitric oxide of an oxidative-stress response that defends Escherichia coli against activated macrophages. Proc Natl Acad Sci U S A 90:9993-9997, 1993.

122. Stamler, J.S. Redox signaling: nitrosylation and related target interactions of nitric oxide. Cell 78:931-936, 1994.

123. Hausladen, A. and Fridovich, I. Superoxide and peroxynitrite inactivate aconitases, but nitric oxide does not. $J$ Biol Chem 269:29405-29408, 1994.

124. Kim, Y.M., Bergonia, H.A., Muller, C., Pitt, B.R., Watkins, W.D. and Lancaster, J.R.J. Nitric oxide and intracellular heme. Adv Pharmacol 34:277-91:277-291, 1995.

125. Crow, J.P. and Beckman, J.S. Reactions between nitric oxide, superoxide, and peroxynitrite: footprints of peroxynitrite in vivo. Adv Pharmacol 34:17-43:17-43, 1995.

126. De Groote, M.A., Ochsner, U.A., Shiloh M., et al. The role of $\mathrm{Cu}, \mathrm{Zn}$ superoxide dismutase (SodC) in Salmonella typhimurium pathogenesis. In Proceedings of the 97th General Meeting of the American Society for Microbilogy.ASM Press, Washington, DC, No.B279 1997.

127. Wink, D.A., Kasprzak, K.S., Maragos, C.M., et al. DNA deaminating ability and genotoxicity of nitric oxide and its progenitors. Science 254:1001-1003, 1991.

128. Juedes, M.J. and Wogan, G.N. Peroxynitrite-induced mutation spectra of pSP189 following replication in bacteria and in human cells. Mutat.Res 349:51-61, 1996.

129. Peunova, N. and Enikolopov, G. Amplification of calcium-induced gene transcription by nitric oxide in neuronal cells [published erratum appears in Nature 1993 Sep 30;365(6445):468]. Nature 364:450-453, 1993.

130. Lander, H.M., Sehajpal, P.K. and Novogrodsky, A. Nitric oxide signaling: a possible role for G proteins. $J$ Immunol 151:7182-7187, 1993.

131. Lepoivre, M., Chenais, B., Yapo, A., Lemaire, G., Thelander, L. and Tenu, J.P. Alterations of ribonucleotide reductase activity following induction of the nitrite-generating pathway in adenocarcinoma cells. J Biol Chem 265:14143-14149, 1990.

132. Melkova, Z. and Esteban, M. Inhibition of vaccinia virus DNA replication by inducible expression of nitric oxide synthase. J Immunol 155:5711-5718, 1995.

133. Rubbo, H., Radi, R., Trujillo, M., et al. Nitric oxide regulation of superoxide and peroxynitrite-dependent lipid peroxidation. Formation of novel nitrogen-containing oxidized lipid derivatives. J Biol Chem 269:26066-26075, 1994.

134. Halliwell, B., Hu, M.L., Louie, S., et al. Interaction of nitrogen dioxide with human plasma. Antioxidant depletion and oxidative damage. FEBS Lett 313:62-66, 1992.

135. Wink, D. A., Grisham M.B., Cook, J. C., Pacelli, R., Liebman, J., Krishna, M., and Mitchel, J. B. Chemical biology of nitric oxide. Direct and indirect effects. 1996. Proceedings of the 2nd International Conference on Biochemistry and Molecular Biology of Nitric Oxide. UCLA, Los Angeles, CA.

136. Pacelli, R., Wink, D.A., Cook, J.A., et al. Nitric oxide potentiates hydrogen peroxide-induced killing of Escherichia coli. J Exp Med 182:1469-1479, 1995. 
137. Noronha-Dutra, A.A., Epperlein, M.M. and Woolf, N. Reaction of nitric oxide with hydrogen peroxide to produce potentially cytotoxic singlet oxygen as a model for nitric oxide-mediated killing. FEBS Lett 321:59-62, 1993.

138. Freeman, B.A., White, C.R., Gutierrez, H., Paler-Martinez, A., Tarpey, M.M. and Rubbo, H. Oxygen radicalnitric oxide reactions in vascular diseases. Adv Pharmacol 34:45-69:45-69, 1995.

139. Park, J.W. Attenuation of p47phox and p67phox membrane translocation as the inhibitory mechanism of Snitrosothiol on the respiratory burst oxidase in human neutrophils. Biochem Biophys Res Commun 220:31-35, 1996.

140. Kanner, J., Harel, S. and Granit, R. Nitric oxide as an antioxidant. Arch Biochem Biophys 289:130-136, 1991.

141. Wink, D.A., Cook, J.A., Pacelli, R., Liebmann, J., Krishna, M.C. and Mitchell, J.B. Nitric oxide (NO) protects against cellular damage by reactive oxygen species. Toxicol.Lett 82-83:221-6:221-226, 1995.

142. Kim, Y.M., Bergonia, H. and Lancaster, J.R.J. Nitrogen oxide-induced autoprotection in isolated rat hepatocytes. FEBS Lett 374:228-232, 1995.

143. Kaplan, S.S., Lancaster, J.R.J., Basford, R.E. and Simmons, R.L. Effect of nitric oxide on staphylococcal killing and interactive effect with superoxide. Infect Immun 64:69-76, 1996.

144. Newton, G.L., Arnold, K., Price, M.S., et al. Distribution of thiols in microorganisms: mycothiol is a major thiol in most actinomycetes. J Bacteriol. 178:1990-1995, 1996.

145. Fairlamb, A.H. and Cerami, A. Metabolism and functions of trypanothione in the Kinetoplastida. Annu Rev Microbiol 46:695-729:695-729, 1992.

146. De Groote, M.A., Testerman, T., Xu, Y., Stauffer, G. and Fang, F.C. Homocysteine antagonism of nitric oxiderelated cytostasis in Salmonella typhimurium. Science 272:414-417, 1996.

147. Tsaneva, I.R. and Weiss, B. soxR, a locus governing a superoxide response regulon in Escherichia coli K-12. $J$ Bacteriol. 172:4197-4205, 1990.

148. Christman, M.F., Morgan, R.W., Jacobson, F.S. and Ames, B.N. Positive control of a regulon for defenses against oxidative stress and some heat-shock proteins in Salmonella typhimurium. Cell 41:753-762, 1985.

149. Radi, R., Beckman, J.S., Bush, K.M. and Freeman, B.A. Peroxynitrite oxidation of sulfhydryls. The cytotoxic potential of superoxide and nitric oxide. J Biol Chem 266:4244-4250, 1991.

150. De Groote, M.A., Granger, D., Xu, Y., Campbell, G., Prince, R. and Fang, F.C. Genetic and redox determinants of nitric oxide cytotoxicity in a Salmonella typhimurium model. Proc Natl Acad Sci U S A 92:6399-6403, 1995.

151. Warren, J.B., Loi, R., Rendell, N.B. and Taylor, G.W. Nitric oxide is inactivated by the bacterial pigment pyocyanin. Biochem J 266:921-923, 1990.

152. Prada, J., Malinowski, J., Muller, S., Bienzle, U. and Kremsner, P.G. Effects of Plasmodium vinckei hemozoin on the production of oxygen radicals and nitrogen oxides in murine macrophages. Am J Trop.Med Hyg. 54:620624, 1996.

153. Bergey's Manual of Determinative Bacteriology, Willians \& Wilkins, 1994. Ed.ninth

154. Corbel, M.J. and Brinley-Morgan, W.J. Genus Brucella. In: Bergey's Manual of Systematic Bacteriology. Volume 1, edited by Krieg, N.R. Willians \& Wilkins, 1984, p. 377-388. 
155. Wilfert C.M. Brucella. In: Zinsser Microbiología, edited by Joklik W.K., Willet H.P., Amos D.B. and Wilfert C.M. Editorial Médica Panamericana S.A., 1994, p. 827-833.

156. Sangari, F.J. and Aguero, J. Molecular basis of Brucella pathogenicity: an update. Microbiologia. 12:207-218, 1996.

157. Canning P.C. Phagocyte Function in Resistance to Brucellosis. In: Advances in Brucellosis Research, edited by Adams, L.G. Texas A\&M University Press, 1990, p. 151-163.

158. Moreno, E. Evolution of Brucella. In: Prevention of Brucelosis in the Mediterranean countries, edited by Plommet, M. Pudoc Scientific Publishers, 1992, p. 198-219.

159. Corbel, M.J. Microbiology of the genus Brucella. In: Brucellosis: Clinical and Laboratory Aspects, edited by Young, E.J. and Corbel, M.J. CRC Press, Inc., 1989, p. 53-72.

160. Kreutzer, D.L., Dreyfus, L.A. and Robertson, D.C. Interaction of polymorphonuclear leukocytes with smooth and rough strains of Brucella abortus. Infect Immun 23:737-742, 1979.

161. Robertson, D.C., Riley, L.K. and Kreutzer, D.L. Intracellular survival of smooth and rough strains of Brucella. In: Microbiology, edited by Schlessinger, D. American Society for Microbiology, 1979, p. 150-153.

162. Riley, L.K. and Robertson, D.C. Ingestion and intracellular survival of Brucella abortus in human and bovine polymorphonuclear leukocytes. Infect Immun 46:224-230, 1984.

163. Harmon, B.G., Adams, L.G. and Frey, M. Survival of rough and smooth strains of Brucella abortus in bovine mammary gland macrophages. Am J Vet.Res 49:1092-1097, 1988.

164. Young, E.J., Borchert, M., Kretzer, F.L. and Musher, D.M. Phagocytosis and killing of Brucella by human polymorphonuclear leukocytes. J Infect Dis 151:682-690, 1985.

165. Orduna, A., Orduna, C., Eiros, J.M., et al. Inhibition of the degranulation and myeloperoxidase activity of human polymorphonuclear neutrophils by Brucella melitensis. Microbiologia. 7:113-119, 1991.

166. Canning, P.C., Roth, J.A., Tabatabai, L.B. and Deyoe, B.L. Isolation of components of Brucella abortus responsible for inhibition of function in bovine neutrophils. J Infect Dis 152:913-921, 1985.

167. Bertram, T.A., Canning, P.C. and Roth, J.A. Preferential inhibition of primary granule release from bovine neutrophils by a Brucella abortus extract. Infect Immun 52:285-292, 1986.

168. Canning, P.C., Roth, J.A. and Deyoe, B.L. Release of 5'-guanosine monophosphate and adenine by Brucella abortus and their role in the intracellular survival of the bacteria. J Infect Dis 154:464-470, 1986.

169. Pizarro-Cerda, J., Moreno, E., Sanguedolce, V., Mege, J.L. and Gorvel, J.P. Virulent Brucella abortus prevents lysosome fusion and is distributed within autophagosome-like compartments. Infect Immun 66:2387-2392, 1998.

170. Morris, J.A. The interaction of "Brucella abortus" 544 and neutrophil polymorphonuclear leucocytes. Ann Sclavo. 19:143-150, 1977.

171. Canning, P.C., Deyoe, B.L. and Roth, J.A. Opsonin-dependent stimulation of bovine neutrophil oxidative metabolism by Brucella abortus. Am J Vet.Res 49:160-163, 1988.

172. Moriyon, I. and Berman, D.T. Effects of nonionic, ionic, and dipolar ionic detergents and EDTA on the Brucella cell envelope. J Bacteriol. 152:822-828, 1982. 
173. Moriyon, I., Gamazo, C. and Diaz, R. Properties of the outer membrane of Brucella. Ann Inst Pasteur Microbiol 138:89-91, 1987.

174. Riley, L.K. and Robertson, D.C. Brucellacidal activity of human and bovine polymorphonuclear leukocyte granule extracts against smooth and rough strains of Brucella abortus. Infect Immun 46:231-236, 1984.

175. Moreno, E., Borowiak, D. and Mayer, H. Brucella lipopolysaccharides and polysaccharides. Ann Inst Pasteur Microbiol 138:102-105, 1987.

176. Martinez, d.T., Pizarro-Cerda, J., Moreno, E. and Moriyon, I. The outer membranes of Brucella spp. are resistant to bactericidal cationic peptides. Infect Immun 63:3054-3061, 1995.

177. Martinez, d.T. and Moriyon, I. The outer membranes of Brucella spp. are not barriers to hydrophobic permeants. J Bacteriol. 175:5273-5275, 1993.

178. Freer, E., Moreno, E., Moriyon, I., Pizarro-Cerda, J., Weintraub, A. and Gorvel, J.P. Brucella-Salmonella lipopolysaccharide chimeras are less permeable to hydrophobic probes and more sensitive to cationic peptides and EDTA than are their native Brucella sp. counterparts. J Bacteriol. 178:5867-5876, 1996.

179. Stabel, T.J., Sha, Z. and Mayfield, J.E. Periplasmic location of Brucella abortus $\mathrm{Cu} / \mathrm{Zn}$ superoxide dismutase. Vet.Microbiol 38:307-314, 1994.

180. Sriranganathan, N., Boyle, S.M., Schurig, G. and Misra, H. Superoxide dismutases of virulent and avirulent strains of Brucella abortus. Vet.Microbiol 26:359-366, 1991.

181. Latimer, E., Simmers, J., Sriranganathan, N., Roop, R.M., Schurig, G.G. and Boyle, S.M. Brucella abortus deficient in copper/zinc superoxide dismutase is virulent in BALB/c mice. Microb.Pathog. 12:105-113, 1992.

182. Tatum, F.M., Detilleux, P.G., Sacks, J.M. and Halling, S.M. Construction of Cu-Zn superoxide dismutase deletion mutants of Brucella abortus: analysis of survival in vitro in epithelial and phagocytic cells and in vivo in mice. Infect Immun 60:2863-2869, 1992.

183. Saha, A.K., Dowling, J.N., LaMarco, K.L., et al. Properties of an acid phosphatase from Legionella micdadei which blocks superoxide anion production by human neutrophils. Arch Biochem Biophys 243:150-160, 1985.

184. Saha, A.K., Mukhopadhyay, N.K., Dowling, J.N., Ficht, T.A., Adams, L.G. and Glew, R.H. Characterization of a phosphomonoesterase from Brucella abortus. Infect Immun 58:1153-1158, 1990.

185. Huddleson, I.F. and Staley, J.T. Catalase activity of the species Brucella as a criterion of virulence. Mich.State College Agr.Expt.Stat.Tech.Bull. 182:631943.

186. Fitzgeorge, R.B., Keppie, J. and Smith, R. The relation between resistance to hydrogen peroxide and virulence in brucellae. J Pathol 89:745-747, 1998.

187. Sha, Z., Stabel, T.J. and Mayfield, J.E. Brucella abortus catalase is a periplasmic protein lacking a standard signal sequence. J Bacteriol. 176:7375-7377, 1994.

188. Jiang, X., Leonard, B., Benson, R. and Baldwin, C.L. Macrophage control of Brucella abortus: role of reactive oxygen intermediates and nitric oxide. Cell Immunol 151:309-319, 1993.

189. Carlsson, J. and Carpenter, V.S. The recA+ gene product is more important than catalase and superoxide dismutase in protecting Escherichia coli against hydrogen peroxide toxicity. J Bacteriol. 142:319-321, 1980.

190. Tatum, F.M., Morfitt, D.C. and Halling, S.M. Construction of a Brucella abortus RecA mutant and its survival in mice. Microb.Pathog. 14:177-185, 1993. 
191. Liautard, J.P., Gross, A., Dornand, J. and Kohler, S. Interactions between professional phagocytes and Brucella spp. Microbiologia. 12:197-206, 1996.

192. Lin, J. and Ficht, T.A. Protein synthesis in Brucella abortus induced during macrophage infection. Infect Immun 63:1409-1414, 1995.

193. Roop, R.M., Price, M.L., Dunn, B.E., Boyle, S.M., Sriranganathan, N. and Schurig, G.G. Molecular cloning and nucleotide sequence analysis of the gene encoding the immunoreactive Brucella abortus Hsp60 protein, BA60K. Microb.Pathog. 12:47-62, 1992.

194. Kohler, S., Teyssier, J., Cloeckaert, A., Rouot, B. and Liautard, J.P. Participation of the molecular chaperone DnaK in intracellular growth of Brucella suis within U937-derived phagocytes. Mol Microbiol 20:701-712, 1996.

195. Caron, E., Cellier, M., Liautard, J.P. and Kohler, S. Complementation of a DnaK-deficient Escherichia coli strain with the dnaK/dnaJ operon of Brucella ovis reduces the rate of initial intracellular killing within the monocytic cell line U937. FEMS Microbiol Lett 120:335-340, 1994.

196. Elzer, P.H., Phillips, R.W., Kovach, M.E., Peterson, K.M. and Roop, R.M. Characterization and genetic complementation of a Brucella abortus high- temperature-requirement A (htrA) deletion mutant. Infect Immun 62:4135-4139, 1994.

197. Elzer, P.H., Phillips, R.W., Robertson, G.T. and Roop, R.M. The HtrA stress response protease contributes to resistance of Brucella abortus to killing by murine phagocytes. Infect Immun 64:4838-4841, 1996.

198. Tatum, F.M., Cheville, N.F. and Morfitt, D. Cloning, characterization and construction of htrA and htrA-like mutants of Brucella abortus and their survival in BALB/c mice. Microb.Pathog. 17:23-36, 1994.

199. Elzer, P.H., Hagius, S.D., Robertson, G.T., et al. Behaviour of a high-temperature-requirement A (HtrA) deletion mutant of Brucella abortus in goats. Res Vet.Sci 60:48-50, 1996.

200. Phillips, R.W., Elzer, P.H. and Roop, R.M., II. A Brucella melitensis high temperature requirement A (htrA) deletion mutant demonstrates a stress response defective phenotype in vitro and transient attenuation in the BALB/c mouse model. Microb.Pathog. 19:227-284, 1995.

201. McCullough, N.B. and Beal, G.A. Growth and manometric studies on carbohydrate utilization of Brucella. J Infect Dis 89:266-271, 1951.

202. Jones, L.M., Montgomery, V. and Wilson, J.B. Characteristics of carbon dioxide-independent cultures of Brucella abortus isolated from cattle vaccinated with strain 19. J Infect Dis 115:312-320, 1965.

203. Smith, H., Willians A.E., Pearce, J.H., et al. Foetal erythritol: a cause of the localization of Brucella abortus in bovine contagious abortion. Nature 193:47-49, 1962.

204. Sangari, F.J., Garcia-Lobo, J.M. and Aguero, J. The Brucella abortus vaccine strain B19 carries a deletion in the erythritol catabolic genes. FEMS Microbiol Lett 121:337-342, 1994.

205. Sangari, F.J., Grillo, M.J., De Bagues, M.P., et al. The defect in the metabolism of erythritol of the Brucella abortus B19 vaccine strain is unrelated with its attenuated virulence in mice [In Process Citation]. Vaccine 16:1640-1645, 1998.

206. Corbel, M.J. Brucellosis: an overview. Emerg.Infect Dis 3:213-221, 1997.

207. Jiang, X. and Baldwin, C.L. Iron augments macrophage-mediated killing of Brucella abortus alone and in conjunction with interferon-gamma. Cell Immunol 148:397-407, 1993. 
208. Lopez-Goni, I., Moriyon, I. and Neilands, J.B. Identification of 2,3-dihydroxybenzoic acid as a Brucella abortus siderophore. Infect Immun 60:4496-4503, 1992.

209. Leonard, B.A., Lopez-Goni, I. and Baldwin, C.L. Brucella abortus siderophore 2,3-dihydroxybenzoic acid protects brucellae from killing by macrophages. Vet.Res 28:87-92, 1997.

210. Denoel, P.A., Crawford, R.M., Zygmunt, M.S., et al. Survival of a bacterioferritin deletion mutant of Brucella melitensis 16M in human monocyte-derived macrophages. Infect Immun 65:4337-4340, 1997.

211. Caron, E., Peyrard, T., Kohler, S., Cabane, S., Liautard, J.P. and Dornand, J. Live Brucella spp. fail to induce tumor necrosis factor alpha excretion upon infection of U937-derived phagocytes. Infect Immun 62:5267-5274, 1994.

212. Caron, E., Gross, A., Liautard, J.P. and Dornand, J. Brucella species release a specific, protease-sensitive, inhibitor of TNF-alpha expression, active on human macrophage-like cells. J Immunol 156:2885-2893, 1996.

213. Martin, N.L. and Hancock, R.E.W. Function and Structure of the Major Components of the Outer Membrane of Gram-Negative Bacteria. In: Advances in Brucellosis Research, edited by Adams, L.G. Texas A\&M University Press, 1990, p. 55-75.

214. Winter, A.J. Outer membrane proteins of Brucella. Ann Inst Pasteur Microbiol 138:87-89, 1987.

215. Verstreate, D.R. and Winter, A.J. Comparison of sodium dodecyl sulfate-polyacrylamide gel electrophoresis profiles and antigenic relatedness among outer membrane proteins of 49 Brucella abortus strains. Infect Immun 46:182-187, 1984.

216. Gamazo, C., Vitas, A.I., Moriyon, I., Lopez-Goni, I. and Diaz, R. Brucella group 3 outer membrane proteins contain a heat-modifiable protein. FEMS Microbiol Lett 112:141-146, 1993.

217. de Wergifosse, P., Lintermans, P., Limet, J.N. and Cloeckaert, A. Cloning and nucleotide sequence of the gene coding for the major 25- kilodalton outer membrane protein of Brucella abortus. J Bacteriol. 177:1911-1914, 1995.

218. Cloeckaert, A., de Wergifosse, P., Dubray, G. and Limet, J.N. Identification of seven surface-exposed Brucella outer membrane proteins by use of monoclonal antibodies: immunogold labeling for electron microscopy and enzyme-linked immunosorbent assay. Infect Immun 58:3980-3987, 1990.

219. Seliutina, D.F., Malikov, V.E., Chibisova, V.A., Gorelov, V.N. and Skavronskaia, A.G. [Immunobiological characteristics of Brucella outer membrane proteins, genetic determinants of which are expressed in Escherichia coli cells]. Mol Gen Mikrobiol.Virusol. 17-20, 1993.

220. Kulakov, I.K., O'Callaghan, D., Ramuz, M., Liautard, J.P. and Skavronskaia, A.G. [A genetic and molecular biological study of the pathogenicity factors in Brucella]. Zh.Mikrobiol.Epidemiol.Immunobiol. 34-39, 1996.

221. Halling, S.M., Detilleux, P.G., Tatum, F.M., Judge, B.A. and Mayfield, J.E. Deletion of the BCSP31 gene of Brucella abortus by replacement. Infect Immun 59:3863-3868, 1991.

222. Verger, J.M. and Grayon, M. Contribution de la biologie moléculaire à la taxonomie du genre Brucella. In: Prevention of Brucelosis in the Mediterranean countries, edited by Plommet, M. Pudoc Scientific Publishers, 1992, p. 187-197.

223. Ficht, T.A., Bearden, S.W. and Marquis, H. Phylogenetic Markers to describe Brucella abortus. In: Advances in Brucellosis Research, edited by Adams, L.G. Texas A\&M University Press, 1990, p. 36-52. 
224. Marquis, H. and Ficht, T.A. The omp2 gene locus of Brucella abortus encodes two homologous outer membrane proteins with properties characteristic of bacterial porins. Infect Immun 61:3785-3790, 1993.

225. Riezu-Boj, J.I., Moriyon, I., Blasco, J.M., Marin, C.M. and Diaz, R. Comparison of lipopolysaccharide and outer membrane protein- lipopolysaccharide extracts in an enzyme-linked immunosorbent assay for the diagnosis of Brucella ovis infection. J Clin Microbiol 23:938-942, 1986.

226. Diaz, R. and Moriyon, I. Laboratory techniques in the diagnosis of human brucelosis. In: Brucellosis: Clinical and Laboratory Aspects, edited by Young, E.J. and Corbel, M.J. CRC Press, Inc., 1989, p. 73-83.

227. Cloeckaert, A., Jacques, I., Bosseray, N., et al. Protection conferred on mice by monoclonal antibodies directed against outer-membrane-protein antigens of Brucella. J Med Microbiol 34:175-180, 1991.

228. Confer, A.W., Tabatabai, L.B., Deyoe, B.L., et al. Vaccination of cattle with chemically modified and unmodified salt- extractable proteins from Brucella abortus. Vet.Microbiol 15:325-339, 1987.

229. Weynants, V., Gilson, D., Cloeckaert, A., et al. Characterization of smooth lipopolysaccharides and O polysaccharides of Brucella species by competition binding assays with monoclonal antibodies. Infect Immun 65:1939-1943, 1997.

230. Bundle, D.R., Cherwonogrodzky, J.W., Gidney, M.A., Meikle, P.J., Perry, M.B. and Peters, T. Definition of Brucella $\mathrm{A}$ and $\mathrm{M}$ epitopes by monoclonal typing reagents and synthetic oligosaccharides. Infect Immun 57:2829-2836, 1989.

231. Perry, M.B. and Bundle, D.R. Lipopolysaccharide Antigens and Carbohydrates of Brucella. In: Advances in Brucellosis Research, edited by Adams, L.G. Texas A\&M University Press, 1990, p. 76-88.

232. Fernandez-Lago, L., Moriyon, I., Toyos, J. and Diaz, R. Immunological identity of brucella native hapten, polysaccharide B, and yersinia enterocolitica serotype 9 native hapten. Infect Immun 38:778-780, 1982.

233. Diaz, R., Toyos, J., Salvo, M.D., et al. Studies on the polysaccharide B and native haptene of Brucella and Yersinia enterocolitica serotype 9. Dev Biol Stand. 56:213-20:213-220, 1984.

234. Aragon, V. Caracterización bioquímica y propiedades inmunológicas de los polisacáridos hapténicos de Brucella. 1994. Universidad de Navarra. Tesis.

235. Aragon, V., Diaz, R., Moreno, E. and Moriyon, I. Characterization of Brucella abortus and Brucella melitensis native haptens as outer membrane O-type polysaccharides independent from the smooth lipopolysaccharide. $J$ Bacteriol. 178:1070-1079, 1996.

236. Bundle, D.R., Cherwonogrodzky, J.W., Caroff, M. and Perry, M.B. The lipopolysaccharides of Brucella abortus and B. melitensis. Ann Inst Pasteur Microbiol 138:92-98, 1987.

237. Bundle, D.R., Cherwonogrodzky, J.W. and Perry, M.B. Characterization of Brucella polysaccharide B. Infect Immun 56:1101-1106, 1988.

238. Brenner, D.J., Davis, B.R., Steigerwalt, A.G., et al. Atypical biogroups of Escherichia coli found in clinical specimens and description of Escherichia hermannii sp. nov. J Clin Microbiol 15:703-713, 1982.

239. Perry, M.B. and Bundle, D.R. Antigenic relationships of the lipopolysaccharides of Escherichia hermannii strains with those of Escherichia coli O157:H7, Brucella melitensis, and Brucella abortus. Infect Immun 58:1391-1395, 1990.

240. Caroff, M., Bundle, D.R. and Perry, M.B. Structure of the Ochain of the phenol-phase soluble cellular lipopolysaccharide of Yersinia enterocolitica serotype O:9. Eur J Biochem 139:195-200, 1984. 
241. Di Fabio, J.L., Perry, M.B. and Bundle, D.R. Analysis of the lipopolysaccharide of Pseudomonas maltophilia 555. Biochem Cell Biol 65:968-977, 1987.

242. Velasco, J., Moll, H., Vinogradov, E.V., Moriyon, I. and Zahringer, U. Determination of the Ospecific polysaccharide structure in the lipopolysaccharide of Ochrobactrum anthropi LMG 3331. Carbohydr.Res 287:123-126, 1996.

243. Velasco, J., Diaz, R., Grillo, M.J., et al. Antibody and delayed-type hypersensitivity responses to Ochrobactrum anthropi cytosolic and outer membrane antigens in infections by smooth and rough Brucella spp. Clin Diagn Lab Immunol 4:279-284, 1997.

244. Velasco, J., Moll, H., Knirel, Y.A., Sinnwell, V., Moriyon, I. and Zahringer, U. Structural studies on the lipopolysaccharide from a rough strain of Ochrobactrum anthropi containing a 2,3-diamino-2,3-dideoxy-Dglucose disaccharide lipid A backbone. Carbohydr.Res 306:283-290, 1998.

245. Sutherland, S.S. and Searson, J. The immune response to Brucella abortus: The humoral response. In: Animal Brucellosis, edited by Nielsen, K. and Duncan, J.R. CRC Press, Inc, 1990, p. 65-81.

246. Westerman, R.B., He, Y., Keen, J.E., Littledike, E.T. and Kwang, J. Production and characterization of monoclonal antibodies specific for the lipopolysaccharide of Escherichia coli O157. J Clin Microbiol 35:679684, 1997.

247. Kondo, S., Sano, Y., Isshiki, Y. and Hisatsune, K. The O polysaccharide chain of the lipopolysaccharide from Vibrio cholerae $\mathrm{O} 76$ is a homopolymer of $\mathrm{N}-[(\mathrm{S})-(+)-2-h y d r o x y p r o p i o n y l]-a l p h a-L-$ perosamine. Microbiology. 142:2879-2885, 1996.

248. Smith, L.D. and Ficht, T.A. Pathogenesis of Brucella. Crit.Rev Microbiol 17:209-230, 1990.

249. Soto, L., Rojas, X. and Alonso, O. Estudio in vitro del efecto de fracciones de pared celular de Brucella sobre la actividad de leucocitos polimorfonucleares bovinos. Arch Med Vet 23:27-33, 1991.

250. Moreno, E., Stackebrandt, E., Dorsch, M., Wolters, J., Busch, M. and Mayer, H. Brucella abortus 16S rRNA and lipid A reveal a phylogenetic relationship with members of the alpha-2 subdivision of the class Proteobacteria. $J$ Bacteriol. 172:3569-3576, 1990.

251. Moreno, E., Berman, D.T. and Boettcher, L.A. Biological activities of Brucella abortus lipopolysaccharides. Infect Immun 31:362-370, 1981.

252. Rasool, O., Freer, E., Moreno, E. and Jarstrand, C. Effect of Brucella abortus lipopolysaccharide on oxidative metabolism and lysozyme release by human neutrophils. Infect Immun 60:1699-1702, 1992.

253. Berman, D.T. and Kurtz, R.S. Relationship of biological activities to structures of Brucella abortus endotoxin and LPS. Ann Inst Pasteur Microbiol 138:98-101, 1987.

254. Price, R.E., Templeton, J.W. and Adams, L.G. Survival of smooth, rough and transposon mutant strains of Brucella abortus in bovine mammary macrophages. Vet Immunol Immunopathol 26:353-365, 1990.

255. Vizcaino, N., Chordi, A. and Fernandez-Lago, L. Characterization of smooth Brucella lipopolysaccharides and polysaccharides by monoclonal antibodies. Res Microbiol 142:971-978, 1991.

256. Diaz, R., Jones, L.M., Leong, D. and Wilson, J.B. Surface antigens of smooth brucellae. J Bacteriol. 96:893901, 1968.

257. Schurig, G.G., Pringle, A.T. and Breese, S.S.J. Localization of brucella antigens that elicit a humoral immune response in Brucella abortus-infected cells. Infect Immun 34:1000-1007, 1981. 
258. Plommet, M. Brucellosis and immunity: humoral and cellular components in mice. Ann Inst Pasteur Microbiol 138:105-110, 1987.

259. Vizcaino, N. and Fernandez-Lago, L. Protection and suppression of the humoral immune response in mice mediated by a monoclonal antibody against the M epitope of Brucella. FEMS Immunol Med Microbiol 8:133139, 1994.

260. Redfearn, M. S. An inmunochemical study of antigens of Brucella extracted by the Westphal Tecnique. 1960. University of Wisconsin, Madison. USA. Thesis.

261. Moreno, E., Pitt, M.W., Jones, L.M., Schurig, G.G. and Berman, D.T. Purification and characterization of smooth and rough lipopolysaccharides from Brucella abortus. J Bacteriol. 138:361-369, 1979.

262. Moreno, E., Berman, D.T. and Boettcher, L.A. Biological activities of Brucella abortus lipopolysaccharides. Infect Immun 31:362-370, 1981.

263. Green, L.C., Wagner, D.A., Glogowski, J., Skipper, P.L., Wishnok, J.S. and Tannenbaum, S.R. Analysis of nitrate, nitrite, and [15N]nitrate in biological fluids. Anal Biochem 126:131-138, 1982.

264. Bradford, M.M. A rapid and sensitive method for the quantitation of microgram quantities of protein utilizing the principle of protein-dye binding. Anal Biochem 72:248-54:248-254, 1976.

265. Chomczynski, P. and Sacchi, N. Single-step method of RNA isolation by acid guanidinium thiocyanate- phenolchloroform extraction. Anal Biochem 162:156-159, 1987.

266. Sambrook, J., Fritsch, E.F. and Maniatis, T. Molecular Cloning: A laboratory manual., Cold Spring Harbor Laboratory Press, 1989. Ed.2nd pp. 7.1-7.78

267. Current Protocols in Molecular Biology. 3 vols. Molecular Biology Technique (vol1). Unit 1.7, John Wiley \& Sons, INC., 1998.

268. Feinberg, A.P. and Vogelstein, B. A technique for radiolabeling DNA restriction endonuclease fragments to high specific activity. Anal Biochem 132:6-13, 1983.

269. Church, G.M. and Gilbert, W. Genomic sequencing. Proc Natl Acad Sci U S A 81:1991-1995, 1984.

270. Xie, Q.W., Cho, H.J., Calaycay, J., et al. Cloning and characterization of inducible nitric oxide synthase from mouse macrophages. Science 256:225-228, 1992.

271. Stuehr, D.J. and Marletta, M.A. Induction of nitrite/nitrate synthesis in murine macrophages by BCG infection, lymphokines, or interferon-gamma. J Immunol 139:518-525, 1987.

272. Jiang, X. and Baldwin, C.L. Effects of cytokines on intracellular growth of Brucella abortus. Infect Immun 61:124-134, 1993 .

273. Parrillo, J.E. Pathogenetic mechanisms of septic shock [see comments]. N Engl J Med 328:1471-1477, 1993.

274. Levin, J., Poore, T.E., Zauber, N.P. and Oser, R.S. Detection of endotoxin in the blood of patients with sepsis due to gran- negative bacteria. N Engl J Med 283:1313-1316, 1970.

275. Moncada, S. and Higgs, A. The L-arginine-nitric oxide pathway. N Engl J Med 329:2002-2012, 1993.

276. Vallance, P. and Moncada, S. Role of endogenous nitric oxide in septic shock. New Horiz. 1:77-86, 1993.

277. Schulz, R., Nava, E. and Moncada, S. Induction and potential biological relevance of a $\mathrm{Ca}(2+)$-independent nitric oxide synthase in the myocardium. Br J Pharmacol 105:575-580, 1992. 
278. Fang, F.C. NO contest: Nitric oxide plays complex roles in infection. The impish NO and several close chemical relatives sometimes combat, otrher times assist a wide range of pathogens. ASM News 63:1998.

279. Bayon, Y., Alonso, A. and Sanchez, C.M. Stimulation of Fc gamma receptors in rat peritoneal macrophages induces the expression of nitric oxide synthase and chemokines by mechanisms showing different sensitivities to antioxidants and nitric oxide donors. J Immunol 159:887-894, 1997.

280. Lowenstein, C.J., Alley, E.W., Raval, P., et al. Macrophage nitric oxide synthase gene: two upstream regions mediate induction by interferon gamma and lipopolysaccharide. Proc Natl Acad Sci U S A 90:9730-9734, 1993.

281. Xie, Q.W., Whisnant, R. and Nathan, C. Promoter of the mouse gene encoding calcium-independent nitric oxide synthase confers inducibility by interferon gamma and bacterial lipopolysaccharide. J Exp Med 177:1779-1784, 1993.

282. Xie, Q.W., Kashiwabara, Y. and Nathan, C. Role of transcription factor NF-kappa B/Rel in induction of nitric oxide synthase. J.Biol.Chem. 269:4705-4708, 1994.

283. Griscavage, J.M., Wilk, S. and Ignarro, L.J. Inhibitors of the proteasome pathway interfere with induction of nitric oxide synthase in macrophages by blocking activation of transcription factor NF-kappa B. Proc Natl Acad Sci U S A 93:3308-3312, 1996.

284. Alonso García, Andrés. La estimulación de los receptores FçR de macrófagos de rata induce la expresión de NOS2 y CINC-1. 1998. Universidad de Valladolid. Tesis.

285. Warner, R.L., Paine, R., Christensen, P.J., et al. Lung sources and cytokine requirements for in vivo expression of inducible nitric oxide synthase. Am J Respir Cell Mol Biol 12:649-661, 1995.

286. Mozaffarian, N., Berman, J.W. and Casadevall, A. Immune complexes increase nitric oxide production by interferon-gamma- stimulated murine macrophage-like J774.16 cells. J Leukoc Biol 57:657-662, 1995.

287. Dykhuizen, R.S., Frazer, R., Duncan, C., et al. Antimicrobial effect of acidified nitrite on gut pathogens: importance of dietary nitrate in host defense. Antimicrob Agents Chemother 40:1422-1425, 1996.

288. Vouldoukis, I., Becherel, P.A., Riveros-Moreno, V., et al. Interleukin-10 and interleukin-4 inhibit intracellular killing of Leishmania infantum and Leishmania major by human macrophages by decreasing nitric oxide generation. Eur J Immunol 27:860-865, 1997.

289. Peterson, P.K., Gekker, G., Hu, S. and Chao, C.C. Human astrocytes inhibit intracellular multiplication of Toxoplasma gondii by a nitric oxide-mediated mechanism [letter]. J Infect Dis 171:516-518, 1995.

290. Lee, S.C., Dickson, D.W., Brosnan, C.F. and Casadevall, A. Human astrocytes inhibit Cryptococcus neoformans growth by a nitric oxide-mediated mechanism. J Exp Med 180:365-369, 1994.

291. Malawista, S.E., Montgomery, R.R. and van Blaricom, G. Evidence for reactive nitrogen intermediates in killing of staphylococci by human neutrophil gtoplasts. A new microbicidal pathway for polymorphonuclear leukocytes. J Clin Invest 90:631-636, 1992.

292. Croen, K.D. Evidence for antiviral effect of nitric oxide. Inhibition of herpes simplex virus type 1 replication. $J$ Clin Invest 91:2446-2452, 1993.

293. Mannick, J.B., Asano, K., Izumi, K., Kieff, E. and Stamler, J.S. Nitric oxide produced by human B lymphocytes inhibits apoptosis and Epstein-Barr virus reactivation. Cell 79:1137-1146, 1994. 
294. Weinberg, J.B., Misukonis, M.A., Shami, P.J., et al. Human mononuclear phagocyte inducible nitric oxide synthase (iNOS): analysis of iNOS mRNA, iNOS protein, biopterin, and nitric oxide production by blood monocytes and peritoneal macrophages. Blood 86:1184-1195, 1995.

295. Adams, L.B., Hibbs, J.B.J., Taintor, R.R. and Krahenbuhl, J.L. Microbiostatic effect of murine-activated macrophages for Toxoplasma gondii. Role for synthesis of inorganic nitrogen oxides from L-arginine. $J$ Immunol 144:2725-2729, 1990.

296. Zhan, Y., Liu, Z. and Cheers, C. Tumor necrosis factor alpha and interleukin-12 contribute to resistance to the intracellular bacterium Brucella abortus by different mechanisms. Infect Immun 64:2782-2786, 1996.

297. Zhan, Y. and Cheers, C. Endogenous interleukin-12 is involved in resistance to Brucella abortus infection. Infect Immun 63:1387-1390, 1995.

298. Zhan, Y. and Cheers, C. Endogenous gamma interferon mediates resistance to Brucella abortus infection. Infect Immun 61:4899-4901, 1993.

299. Jones, S.M. and Winter, A.J. Survival of virulent and attenuated strains of Brucella abortus in normal and gamma interferon-activated murine peritoneal macrophages. Infect Immun 60:3011-3014, 1992. 